-14

(4) I) m m m m

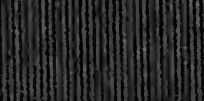




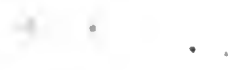

$+$ 


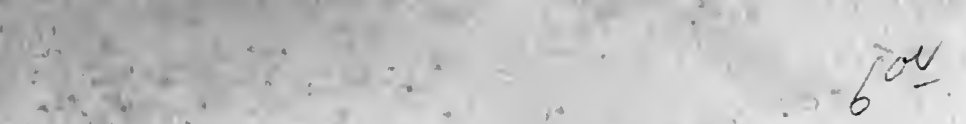

$\therefore \div$

Au)

$\therefore \quad \therefore \quad 0 p 176$

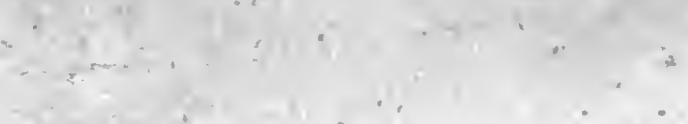

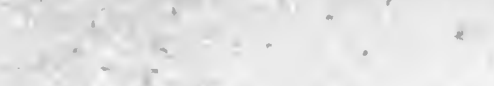





\section{FOREIGNERS IN TURKEY}

THEIR JURIDICAL STATUS 


\section{Digitized by the Internet Archive in 2007 with funding from Microsoft Corporation}




\title{
FOREIGNERS IN TURKEY
}

\author{
THEIR JURIDICAL STATUS
}

BY

\section{PHILIP MARSHALL BROWN}

11

Assistant Professor of International Law and Diplomacy in Princeton

University. Formerly Secretary and Charge d'Affaires of the American Embassy in Constantinople, and Minister to Honduras

PRINCE'TON UNIVERSITY PRESS

PRINCE'TON

LONDON: HUMPHREY MILFORD

OXFORD UNIVERSITY PRESS

1914 
Copyright, 1914, by

Princeton University Press

Published October, 1914

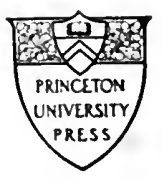




\section{PREFACE}

The rights and privileges of foreigners in Turkey are extensive and anomalous in character.

Under the extraordinary régime of the Capitulations the Turks have retained but few of the rights of territorial sovereignty in respect to jurisdiction over resident foreigners.

The result of this condition of affairs has been an attitude of irritating superiority on the part of the privileged foreigner; a corresponding resentful hostility on the part of the humiliated Turk; and incessant diplomatic controversies of a most trying nature.

When an official in the American Embassy to Turkey the writer came to realize the general need of a clearer understanding in regard to the exact rights of foreigners as distinguished from their privileges and, in some instances, from their undue pretensions. This understanding seemed necessary quite as much for the purpose of doing justice to the sovereign rights of Turkey as for the purpose of protecting the just rights of foreigners.

To discover the precise juridical bases of these rights was not an easy task because of the fact that the sources of information were scattered, incomplete, and required considerable comparative study.

This volume presents in somewhat condensed form 
the results of a special investigation begun several years ago in Constantinople, and completed at Cambridge, Massachusetts, largely by the aid of the remarkable Ottoman Collection in the library of Harvard University, and the helpful suggestions of George Grafton Wilson, Ph.D., LL.D., Professor of International Law in that institution.

The writer has aimed first of all to indicate the origins of so-called exterritorial rights; secondly, to set forth in the form of a brief code the juridical rights enjoyed by foreigners in Turkey; and thirdly, to find a working hypothesis on which to base those readjustments which are bound to come in the relations between the Sublime Porte and the Powers if the Ottoman Empire is to be allowed a normal, independent development as an equal member in the family of nations.

It is hoped that the material here gathered together and the views presented may prove of some slight value to those interested in this particular problem and the unusual questions of international law it involves. Philip Marshall Brown.

May 25, I9I4.

Princeton, New Jersey. 


\section{CONTENTS}

CH APTER

PAGE

PREFACE . . . . . . . . . iii

I-Origin of the Rights of ForEIGNERS • • • • • • • . $3^{-24}$

Introduction $\quad \cdot \quad \cdot \quad \cdot \quad \cdot \quad \cdot \quad \cdot \quad 3$

Moslem law concerning foreigners 4

International usage concerning foreigners prior to $\mathrm{I} 453$. . .

Legal status of non-Moslem Ottoman subjects . . . . . .

I8

II-The Capitulations

Charter of rights granted to Genoese of Galata .

Treaty of $\mathrm{I} 454$ between the Turks and the Venetians

28

Privileges granted to French in I 528

Treaty of I535 between Sultan Soliman II and Francis I . . The French Capitulations of I740 33

Modifications of Capitulations in I 867

III-The Juridical Rights of ForeignERS

A. Immunities of jurisdiction in cases involving foreigners of the same nationality . . 
I. Jursidiction of consular tribumals . . . . . . 52

2. Courts and procedure . . 54

3. Law administered . . . 59

4. Execution of law . . . 6 I

B. Inmmunities of juriscliction in cases involving foreigners of different nationality . . . 66

I. Jurisdiction of consular tribunals . . . . . . 66

2. Courts and procedure . . 69

3-4. Law administered. Execution of law. . . . .

IV-The Juridical Rights of ForeignERs (Continued)

C. Immunities of jurisdiction in matters affecting both foreigners and Ottoman subjects .

I. Jurisdiction of Ottoman tribunals . . . . . . 75

2. Courts and procedure . . $8 \mathrm{I}$

3. Law administered . . . $\quad 87$

4. Execution of law . . . . . 89

D. Inviolability of domicile . . 90

E. Special immunities . . . . . 92

V-IMMUNities of JURISDiCTION AND INTERNATIONAL LAW . . . . IOI-II8 Rights of foreigners the main concern of international law . . IOI 
International private law an integral part of international law.

Opinions of international law publicists . . . . . . . . 106

General conclusions . . . . I Iо

Application of general conclusions

to problem . . . . . . . II2

Suggested solution of problem . $\quad$ I I 4

Appendix. Regulations in force in the Consular Courts of the United States in the Ottoman Dominions . . . . . .

Selected Bibliography . . . . $\quad$ I 35

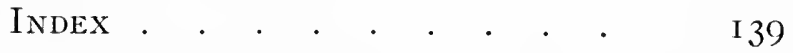




\section{ORIGIN OF THE RIGHTS OF FOREIGNERS}





\section{CHAPTER I}

\section{Origin of the Rights of Foreigners}

\section{INTRODUCTION}

The origin of the exterritorial rights $^{1}$ so long enjoyed by foreigners in Turkey, as well as the perpetuation of these special immunities, has long been ascribed to the necessity of protection from the inequalities and rigors of Moslem law as applied to non-Moslems. ${ }^{2}$

It is also held that the existence of this régime of exceptional privileges is derogatory to the sovereign, independent rights of Turkey since its formal admission into the family of nations by the Treaty of Paris in $1856 .^{3}$

A careful study of the subject, however, may lead

${ }^{1}$ Exterritoriality, as has been pointed out by Bonfils and other recent writers on international law, is a fiction which is inadequate and misleading. It is not true that a foreigner enjoying so-called exterritorial rights carries with him his own laws, and that he is subject to the jurisdiction of his own country: Foreigners in Turkey, for example, hold land in accordance with Ottoman law and jurisdiction. The term immunity of jurisdiction is much more accurate and satisfactory though exterritoriality has acquired by usage a definite place in the phraseology of international law. See Bonfils, Droit International Public, sections 337 and 693. See also Wilson and Tucker, International Law, p. 142. (5th ed.)

2 Bonfils, Sec. 80.

${ }^{3}$ Hall, International Law, p. 52 (6th ed.). 
one to doubt the correctness of both these points of view. It is possible to regard this privileged status of foreigners, not as a bitter humiliation for the Turk, but rather as very much to his credit. Instead of treating immunities of jurisdiction as exceptions to international law, and hence, as affronts to Turkish sovereignty, they may properly be regarded as evidence of a more enlightened and a more liberal interpretation of the law of nations than has yet been granted in Europe, the place of its origin, though no: of its exclusive development, or application.

Recognizing therefore the existence of another point of view of this subject than that generally accepted, we may proceed first to an examination of the primary causes and the peculiar conditions which gave rise to these immunities of jurisdiction; secondly, to an analysis of these privileges; and thirdly, to a determination of their precise relation to international law.

\section{MOSLEM LAW CONCERNING FOREIGNERS}

The conventional method of explaining the farored status of foreigners in Turkey is by adverting to the fact that, according to the Koran all non-Moslems must obtain special guarantees (eman), or be considered as members of the "house of war" (Dar-ulharb), with whom perpetual hostilities are enjoined in the absence of a truce ( soulh $).{ }^{4}$ Such an explanation

4 See Report on the Capitulations by Van Dyck in Senate Ex. Doc. 3. Special Session of Senate of 46 th Congress, p. 3I. See also D'Ohsson, Tableau General de L'Empire Ottoman, pp. 39-4I. 
is inadequate being but partially true, and only to be accepted in a qualified sense.

It is true that the Prophet Mohammed seemed to consider all mankind as divided into two opposing camps: that of the "House of Islam" (Dar-ul-islam), and that of all unbelievers, the "House of war"." But Mohammed failed to maintain a rigid distinction in this respect. As a practical statesman, if not as a tolerant Caliph, he provided that all conquered nonMoslems, might live in peace under Moslem jurisdiction by paying tribute (haradj) ${ }^{6}$ Moreover, in the mass of conflicting opinions attributed to the Prophet in the Koran one finds frequent commands to observe a particularly considerate attitude towards "the people of the Book" (Kiafir-kitaby), as Mohammed chose to denote Christians and Jews alike, in distinction from genuine pagans or idolators (Mushrikin), towards whom no mercy was to be shown. ${ }^{8}$

The designation of non-Moslems as members of "the house of war," therefore, would seem to have no practical value in determining the juridical status of foreigners in Turkey. It may properly be considered

5 The Koran, Sura XLVII, verse 4. "When ye encounter the infidels, strike off their heads till ye have made a great slaughter among them, and of the rest make fast the fetters."

${ }^{6}$ Koran, Sura IX, verse 29.

7 Koran, Sura V, verses 72, 73. "Verily they who believe, and the Jews, and the Sabeites, and the Christians-whoever of them believeth in God and in the last day, and doth what is right, on them shall come no fear, neither shall they be put to grief."

${ }^{8}$ Koran, Sura IX, verses I-5. 
as an approximate equivalent of hostis as applied by the Romans to foreigners, or of barbarian as used by the Greeks.

While Islam is truly "a gospel, code and constitution," it has, however, like the American Constitution, been amplified and adapted to altered circumstances in ways not probably anticipated by its founder. The universally accepted authority in Moslem jurisprudence in Turkey is the general code Multcka-ul-cbhar ("confluence of the seas") drawn up by Sheikh Ibrahim of Aleppo by order of Soliman II. ( I 520-I 566). This code comprises five codes, namely, the religious, civil, commercial, political, and military codes. ${ }^{\mathbf{}}$ It is to the political code that we must refer in order to determine the status of foreigners in Turkey from the Moslem point of view.

Chapter III. of the political code, entitled Foreigners in Moslem Lands, reads as follows:

When he enters with the express permission of the sovereign or of his representatives, the foreigner ought to enjoy in Moslem territory the protection of the laws. Commentary. By this permission, protection and safeconduct (eman) is accolded to the foreigner who, in consequence, is called Mustemin, that is to say, placed ander the protection of the State. If necessary, any Moslem, provided he be a freeman, may also grant to a foreigner at the frontier, entrance into the country, and his guarantee should be respected. ${ }^{10}$

9 D'Ohsson, op. cit., pp. 39-4I. Also, Miltitz, Manuel des Consuls, Appendix VIII, volume I, containing excellent résumé of Ottoman legislation.

${ }^{10}$ D'Ohsson, vol. IV, p. 37. Also, Steen de Jehay, $D \mathcal{c}$ la situation legale des sujets Ottomans non-Musulmans, p. 2I. 
That nothing invidious is intended by this designation of Mustemin is proved by the interesting fact that the same term is applied to the Moslem in foreign lands.

A Moslem should not go to a foreign land except under the pledge of a public safeconduct. Commentary. Likewise he should then bear the title of Mustemin, as the foreigner in Moslem lands. (Chapter IV.) ${ }^{11}$

It would be difficult to express in simpler terms the rights of foreigners under the law of nations than in the words of this Moslem code: "when he enters with the express (or implied) permission of the sovereign or of his representatives, he ought to enjoy ... the protection of the laws." Such a liberal, tolerant point of view conflicts with the theory previously alluded to, namely that all unbelievers must be warred against until they are conquered or obtain special guarantees by means of a truce.

It is clear both by Moslem law and practice that a foreigner (Mustemin) may enter Turkey without the necessity of first obtaining specific guarantees by treaty or otherwise; and that he is entitled to enjoy full protection of the law. The most eloquent proof of this fact is found in the experience of the Spanish Jews, ${ }^{12}$ who, driven forth by the Inquisition and deprived of all foreign protection, found a welcome asylum under the Star and Crescent, and were permitted to enjoy

${ }_{11}$ D'Ohsson, vol. IV, p. 44.

12 Steen de Jehay, op. cit., p. 347. Also, Young's Corps de Droit Ottoman, vol II, sec. XXVIII. 
with other non-Moslem subjects of the Sultan extensive immunities of juriscliction.

We may therefore conclude that the theory of an open and irreconcilable hostility between Moslem law and the law of nations as regards the rights of foreigners is not based on fact. We are obliged consequently to look elsewhere for a satisfactory explanation of the origin of the special immunities of jurisdiction so long enjoyed by foreigners in Turkey. It is important for this purpose to determine what had been the established practice in regard to foreigners, of those nations having relations with the Orient previous to the time of the capture of Constantinople by the Turks. It is also important to determine the legal status of those non-Moslems who came under the domination of the Turks.

INTERNATIONAL USAGE CONCERNING FOREIGNERS PRIOR TO I 453

It has been remarked that "commerce has been the cradle of international law." The venturesome trader, whether on the Baltic or on the Mediterranean, was the principal factor in the early development of the rules of peaceful intercourse between nations. ${ }^{13}$ The Rhodian Laws undoubtedly had their origin in the extension of commerce, as also the rules determining the rights and duties of consuls. ${ }^{14}$ Thus, the alien

${ }^{13}$ Hautefeuille, IIistoire de Droit Maritime International, pp. 78-79.

"Wilson and Tucker, pp, 17-18, 189-191 ; Hautefeuille, op. cit., pp. 95-99. 
who at first was treated as barbarian and hostis, who was denied any legal standing in the country where he might be sojourning or domiciled for purposes of trade, was able, nevertheless, through the exigencies of commerce to obtain extensive privileges. What precisely was the nature of those privileges, and how far they had become established usage at the time of the Turkish conquest of Constantinople are questions of especial interest in determining the origin and nature of the immunities of jurisdiction granted to foreigners after the conquest.

Herodotus is authority for the statement that the Phoenicians from Tyre settled at Memphis in Egypt possibly as early as the reign of Proteus (I294-I244 B.C.), and that they were permitted to have separate temples for worship. ${ }^{15} \mathrm{King}$ Amasis ( $579-526$ B.C.), according to Herodotus, allowed Greek merchants to establish themselves at Naucratis, and permitted them to be judged by their own magistrates according to their own laws and customs. ${ }^{16}$

The Athenians provided proxenoi to attend to the wants of strangers and adjudicate their differences. These officials enjoyed special privileges and immunities, and were often designated by the parent state of the foreigners concerned. ${ }^{17}$

The office of practor peregrimus was early instituted at Rome to judge between foreigners, as well as be-

15 Herodotus, II, 112.

18 Ibid., II, I78-I 79.

17 Miltitz, I, p. II. 
tween Romans and foreigners. ${ }^{18}$ The Emperor Claudius (4I-54 A.D.) granted to the merchants of Cadiz the privilege of choosing their own magistrate and of being exempted from the jurisdiction of the Roman courts. ${ }^{19}$

The extraordinary privileges granted by the laws of the Visigoths in the time of Theodoric (453-466 A.D.) allowing foreign merchants in Spain to try their cases before their own magistrates (telonarii), would seem to correspond closely to the privileges of for. eigners in Turkey at the present time. ${ }^{20}$

Justinian allowed the Armenians residing in Constantinople to settle questions of marriage, inheritance, etc., according to their own laws,- - a privilege they have enjoyed ever since. ${ }^{21}$

The Caliph Omar granted to the Greek Monks in Palestine about 636 A.D., special privileges in the way of exemptions from local jurisdiction. ${ }^{22}$

As early as the ninth century, Arab merchants formed a settlement at the port of Canton, China, and were allowed to be ruled and judged by their own Cadi. ${ }^{23}$

18 Ibid., I, p. 14.

${ }^{19}$ Ibid., I, p. 15.

${ }^{20}$ Dum transmarini negociatores inter se causam, nullas de sedibus nostris eos audire presumat, nisi tantummodo suis legibus audiantur apud telonarios suos. Quoted by Miltitz (I, p. I6I) from Leges Visigoth. Liv. XI. Tit. III. Art. 2.

${ }^{21}$ Edwin Pears, Fall of Constantinople, p. I44.

22 G. Pelissié du Rausas, Le Régime des Capitulations dans L'Empire Ottoman, p. 9.

${ }^{23}$ Wilhelm Heyd, Histoire de Commerce de L'Orient, II, p. 246. 
There is evidence that Charlemagne in the ninth century obtained from the Caliph Haroun-el-Raschid special guarantees and privileges for French merchants. ${ }^{24}$

The entertaining account given in the Chronique de $N_{e s t o r}{ }^{25}$ of the early diplomatic relations between Russia and Constantinople discloses the interesting fact that the Varangians (Warings), ${ }^{26}$ who were of the same Scandinavian stock as the English, made treaties with the Emperors of Byzantium in 907, 912. and 945 A.D., containing stipulations of an exterritorial character. The treaty of 912 included provisions for trial according to Rusian law, of Russians charged with assault; for the support of accusations by oath or by credible witnesses; for cases of shipwreck ; for extradition; and for the administration by Russian representatives in Constantinople of the property of Russians dying intestate. ${ }^{27}$ Nestor gives the text of the treaty of 945 , and as the earliest documentary evidence of the granting of immunities of jurisdiction to foreigners, it is of interest to quote here two Articles, translated from the quaint French text of Louis Paris. ${ }^{28}$

If a Russian should attempt to steal from any one in our Empire, he shall be severely punished for that act; and if he shall have accomplished the theft, he shall pay

${ }^{24}$ Du Rausas, op. cit., p. I I.; Hautefeuille, op. cit., p. 96.

2.5 Louis Paris, Chronique de Nestor, Paris, I834-35.

${ }^{20}$ Gibbon, Decline and Fall of the Roman Empire, vol. IV, ch. LV, sec. III; Pears, Fall of Constantinople, pp. I49-I50.

27 Chronique de Nestor, pp. 36-44.

28 Ibid., pp. 57-64. 
double the value of the object stolen. It shall be the same for the Greek in respect to the Russian; the guilty person, moreower, shall be punished in accordance with the lai's of his country. (Article IV.)

"If the Greeks who are under our sway should icmmit any crime, the Great Russian Prince shall in nowise exact satisfaction; but he will azeait the orders of our Tzar (Emperor of Byzantium) for the infliction of the punishment which their crime shall have deserved." (Article X.)

We thus have five hundred years before the capture of Constantinople by the Turks treaty agreements granting to foreigners very similar exterritorial privileges to those granted in turn by the Sultans of 'Turkey, with this important difference, however, that while the earlier privileges were reciprocal in character, the immunities of jurisdiction which still exist in the Ottoman Empire are entirely one-sided concessions on the part of the Turks.

The practice of conceding to foreign merchants the right to carry with them the jurisdiction of their own laws outside their own territory became quite general with the gradual extension of commerce. It is fitting at this point to draw attention to the fact that as stated by Professor Holland "the notion of a territorial law is European and modern." The same writer also observes that:

There is a stage in civilization at which law is addressed, not to the inhabitants of a country, but to the members of a tribe, or the followers of a religious system, irrespectively of the locality in which they may happen to be. This is the "personal" stage in the development of law. The govermments which the barbarians established on the ruins of the Roman empire did not administer one system of justice applicable throughout a given ter- 
ritory, but decided each case that arose in pursuance of the personal law of the defendant; so that, according to an often-quoted passage in one of the tracts of Bishop Agobard, it might well happen that "five men, each under a different law, would be found walking or sitting together." In one and the same town the Frank, the Burgundian and the Roman lived each under his own system of law. ${ }^{29}$

Treating of this same subject, Professor Emerton has remarked that:

The German thought of his legal rights as belonging to him, not because he was a member of the state, but because he was himself, the son of his fathers, and the heir of all that had seemed right to them. His law was a part of himself. He could no more change it or part with it than he could change or part with his own existence. If he went into the territory of another people, he carried his law with him and looked to have it respected. This notion of law is what is called by scholars the idea of the "personality of law," as distinguished from the "territoriality of law." 30

The particular instances we are considering of exterritorial privileges granted to foreigners should not, therefore, be regarded as anomalous in character, but rather as in accordance with usage which became generally recognized with the gradual extension of commerce.

To continue our investigation: in the year 991, the Greek Emperor at Constantinople permitted the Venetians clomiciled there to be judged by their own magistrates (Bajuli); $;^{31}$ and the "Golden Bull" (Bulla

29 T. E. Holland, Elcments of Jurisprudence, p. 40 or (Ioth ed.). ${ }^{30}$ Ephraim Emerton, Introduction to the Study of the Middlc Ages, p. 75.

${ }^{31}$ Pears, op cit., p. 158. 
aurca) of the Emperor Alexis, promulgated in II99, gave them the extraordinary privilege of haling his own stujects in certain instances before Venetian magistrates to be judged according to Byzantine law. ${ }^{32}$ The Venetian quarter of Constantinople which was entirely withdrawn from local jurisdiction comprised more than three eighths of the city. ${ }^{33}$

The Genoese in I 26 I obtained permission to establish on the opposite shore of the Golden Horn the separate town of Galata where they maintained not only an entirely distinct jurisdiction, but were even at times openly hostile to the Imperial authorities of Constantinople. ${ }^{34}$ During the siege of the city by the Turks in I 453, the Genoese promised to remain neutral provided they were left in the undisturbed enjoyment of their independent rights in Galata. It should be noted, in passing, that while the Turks did not fully keep their word in this respect, they did confirm to the Genoese their immunities of jurisdiction.

The universality of the custom of granting exterritorial privileges to foreigners is evidenced by the different codes governing maritime intercourse from early times. One of the cardinal principles of the Hanseatic League was that its citizens should be judged by their own laws and customs wherever they might engage in commerce. ${ }^{35}$ The German merchants and

32 Sir Travers Twiss, Law of Nations, p. 450. (Ed. 1884.)

${ }^{33}$ Heyd, op cit., I, 248.

${ }^{34}$ Pears, p. I58; Heyd, I, 248; Hautefeuille, p. 99; Gibbon, V, ch. LXIII. Miltitz, op. cit., II, pp. 80-90. See also infra, p. 27. ${ }^{35}$ Miltitz, I, p. I4I; Le régime des Capitulations by "Ancien 
other inhabitants of Wisby on the island of Gothland in the Baltic evidently enjoyed from as early as the I2th century exterritorial privileges in the Republic of Novgorod in Russia. ${ }^{36}$ It is of interest to note that while these privileges were granted under the form of municipal statutes (Skraa), they were actually of a reciprocal nature, and were possibly excerpts from the famous Laws of Wisby, which served as a kind of international law for the merchants of those northern nations. That the Amalfitan Tables provided for exterritorial jurisdiction is evident from the fact that Amalfi in 1093, if not earlier, maintained its own consular court in the neighboring port of Naples. ${ }^{37}$

Several of the Italian cities, such as Pisa and Ragusa. early obtained exterritorial privileges from the Greeks and from the Saracens; and after the conquests made by the Crusaders the practice became general. ${ }^{38}$ Pisans, Venetians, and other foreigners, including Moslems. were allowed exterritorial jurisdiction in their own quarters in Jerusalem, as well as in many other places in the possession of the Latin conquerors, such as Beirut, Jaffa, Cyprus, and Rhodes. ${ }^{39}$

In I I73, the Pisans obtained special concessions from Saladin, Sultan of Egypt, on condition that they should not transport any Crusaders! ${ }^{40}$

\footnotetext{
Diplomat," p. 28; Pardessus, La Collection des lois maritimes antericures au XVIII siecle, T.II.Ch.XIV.

36 Miltitz, I, pp. 40I-408; Pardessus, III, pp. 493-494.

37 Pardessus, $\mathrm{I}$, ch. 4 .

38 Rausas, p. I2; Bonfils, op. cit., sec. 735 with note.

39 Heyd, op. cit., I, pp. I58-161. Rausas, ch. V.

40 Rausas, p. I2.
} 
In 1229, the Venetians were granted by the Sultan of Aleppo the right to establish a church, countinghouse, and magistracy of their own. ${ }^{41}$

The Mameluke Sultan, Maleck-Almazor, granted the Genoese Consul in Alexandria at about this time the right of jurisdiction in suits between Genoese and Saracens, as well as between Genoese and other Christians. ${ }^{42}$

King Louis, the Saint, arranged with the Sultan of Egypt in 1252 for consular courts at Tripoli and Alexandria. ${ }^{43}$

Somewhat later, on the initiative of the Sultan of Egypt, an agreement was entered into with the Grand Master of Rhodes whereby the latter was allowed to have representatives in Jerusalem and other places held by the Saracens. He was also permitted "to protect all Christians, whomsoever, who might be exposed to injuries or insults from Moslems."

It is of especial interest to note that, while the Christians were obtaining the above enumerated privileges from the Saracens, the Moslems in turn residing in Corsica and Sicily were allowed to have their own judges and separate jurisdiction. ${ }^{45}$

So general had become the custom of according special privileges to foreigners that by the beginning

${ }^{41}$ D. B. Warden, The Origin, Nature, and Infucnce of Consular Establishments, p. 52.

42 Ancien Diplomat, p. 48.

43 Rausas, p. 12.

44 Ancien Diplomat, p. 48.

${ }_{45}$ M. F. Elie de la Primaudaie, Les Arabes en Sicilic et en Italic, p. 319 . 
of the ${ }^{5} 5^{\text {th }}$ century, Italian Consuls possessing extensive judicial functions were to be found in The Netherlands ${ }^{46}$ and even in London. And finally, as perhaps the most significant of all these various early instances of exterritorial jurisdiction, we have the extraordinary fact that sixty years before the capture of Constantinople the Turks had been permitted to have in that city their own Mahometan community under the administration of a Cadi in accordance with Moslem Sheri law. ${ }^{47}$

It may be claimed that many of these concessions granted to foreigners were for services rendered; for promises of support, as in the case of the Genoese. It may also be asserted that this practice was based on mutual prejudice and distrust: that foreigners would not trust themselves to the jurisdiction of other nations. It may be insisted that all such privileges were obtained mainly through the exigencies of commerce,-from the necessity of giving a quid pro quo rather than from a liberal, tolerant conception of the rights of aliens. The subject certainly admits of discussion and perhaps of controversy. It would, however, serve no particular purpose at this point to do more than emphasize the important fact, that when the Crescent supplanted the Cross on the dome of St. Sophia, it had become the almost universal custom to grant to foreigners extensive immunities of jurisdiction.

46 Bonfils, sec. 737 with note; Miltitz, II, p. 152.

47 Ancien Diplomat, p. 47. 
LEGAL STATUS OF NON-MOSLEM OTTOMAN SUBJECTS

The principal concern of Mohammed the Conquerer immediately after the capture of Constantinople was the establishment of an effective system of administration which should relieve the government of needless embarrassments, and prove suitable to the needs of his newly conquered Christian subjects.

His idea was extremely simple. He aimed to leave the Greeks to the fullest practicable extent in the free enjoyment of their own laws and customs under the responsible control of their Patriarch who should serve as their intermediary or ambassachor before the Sublime Porte. Within four days after his triumphal entry into the capital, Mohammed induced the fanatical monk, Georges Scholarius, to occupy the vacant throne of the Patriarchate. ${ }^{48}$ The Sultan himself assisted in state at the investiture of the new Patriarch, on whom, as the spiritual successor of the Greek Emperors, Mohammed conferred the unusual title of Mil'let Bashi, "Head of the Nation." ${ }_{49}$ He also solemnly granted to the Patriarch and his successors, an almost unrestricted jurisdiction over the members of the Greek "nation." Unfortunately, the original Berat of Mohammed confirming these extraordinary privileges has disappeared. Successive Sultans have most explicitly reaffirmed

${ }^{48}$ Steen de Jehay, op. cit., pp. 87-90; Sir Charles Eliot (Odysseus) Turkey in Europe, pp. 266-267. (Ed. 1900.)

49 The term mil'let, meaning nation, has been replaced in Turkish official documents by djema'at, signifying community. Steen de Jehay, p. 83. 
them, however, and except for curtailments which were inevitable in the progress of four centuries and more, these exceptional powers are still asserted by the Greek Patriarch, as well as by the heads of other religious communities which later received similar grants. ${ }^{50}$

Although the judicial functions of the Mil'let Bashi have gradually become reduced to questions affecting principally the personal status ${ }^{51}$ of members of the various communities, such as marriage, divorce, dowry and inheritance, the tendency of these communities to maintain a national solidarity and political exclusiveness has been very marked. The collection of taxes has usually been made through the heads of these Mil'lets, ${ }^{52}$-an arrangement which, while convenient for both the Government and its non-Moslem subjects, serves very distinctly to emphasize their peculiar juridical status as tributary nations under the suzerainty of the Sultan. The invidious capitation tax (kharadj), formerly extracted from Christians in token of submission, as well as the offensive designation of Rayah

${ }^{50}$ Young, Corps de Droit Ottoman, II, sec. XXII; Steen de Jehay, ch. II ; Eliot, op. cit., pp. 296-297, 302; Baron de Testa, Receuil des Traités de la Porte Ottomane, vol. V, p. I7o.

${ }^{51}$ Bluntschli in the note to section 379 of his Droit International, (ed. 1874) says: "Le principe du status personnel, en vertu duquel la loi du pays d'origine suit la personne partout ou elle se rend, s'applique sur tout aux questions relatives à l'état et à la capacité des personnes et aux successions; c'est ce même principe qui determine les conditions requises pour la validité d'un mariage, les questions de tutelle, les conditions requises pour succeder, etc." See also Young, II, p. 2; Steen de Jehay, p. 12 .

${ }^{52}$ Steen de Jehay, note on p. II. 
(sheep), has been abolished. In its place was substituted in 1856 the military exemption tax (bedel-iaskeryc) which has naturally fallen almost entirely on non-Moslem subjects owing to the unwillingness of the Turks to incorporate any unbelievers in the army, and on the other hand, to the unwillingness of the non-Moslems to serve in the army. ${ }^{53}$

The question of compulsory military service and other questions concerning the right to vote and the alleged right of national representation in the Turkish Parliament, raised after the Revolution of the Young Turks in 1908, have all served to reveal the extraordinary pretensions of the Greek and Armenian Patriarchs, as well as of the heads of the other communities, to represent their "nations" in a political, capacity before the Sublime Porte. One of the chief embarrassments of the new constitutional régime in Turkey was the unwillingness of the various communities, particularly that of the Greeks, to subordinate their national sentiments to the broader and superior claims of Ottoman nationality. ${ }^{54}$

Such an abnormal state of affairs, - the existence of veritable imperia in imperio,-cannot be expected to continue indefinitely. But as concerns those immuni-

${ }^{53}$ Ibid., pp. 8-II. The Young Turks after their revolution of 1908 tried compulsory military service as a means of Ottomanizing their diverse non-Moslem fellow subjects. It was found, however, that this plan would not work, and it was accordingly abandoned.

${ }^{54}$ The Young Turks perhaps committed an irretrievable blunder in treating with the respective religious communities as distinct nations, and in determining representation in parliament 
ties of juriscliction in matters relating to the personal status of non-Moslem subjects which were granted spontaneously by Mohammed the Conqueror as an act of constructive statesmanship, it would seem likely that such privileges would continue to exist for a long time to come.

The reason for the perpetuation of these privileges, in last analysis, is to be found in the fact that the Moslem confounds race, religion, and law, as one and the same thing. The Sheri,- the union of the Koran and all sacred law,-is the basis of all Mohammedan law and legislation on an immense variety of subjects. Its prescriptions both as to rights and obligations can only apply in toto to the followers of the Prophet. If this be true in such matters as questions of personal status, then non-Moslems, as well as Moslems, must be permitted to observe their own laws and customs. ${ }^{55}$

on the basis of nationalities rather than on a strictly Ottoman basis. Correspondence and diplomatic negotiations with the Greek Patriarch on the subjects of recruitment, electoral rights, etc., were carried on by the Grand Vizier as if with the ambassador of an independent nation.

${ }_{55}$ The observations of Du Rausas (p. 19) in this connection are of interest: "Or la loi religieuse est nécessairement personelle. Elle est faite pour les croyants et pour les croyants seuls; elle ne regit et ne protège qu'eux. Tous les rapports juridiques se résolvant en rapports religieux, le droit est en quelque sorte une grâce divine dont seule peuvent bénéficier les adeptes de la religion." Steen de Jehay (p. 22) also presents some interesting observations in the same connection: "Quel devait donc etre le traitement à réserver aux infidèles soumis par la conquête dans tous les cas où la loi musulmane ne pouvait ni leur être appliquée ni être acceptée par eux? Le Scher'i lui-mème distingue à cet égard entre les idolâtres ou athées (muchrik) et les 
Thus while Mohammed may have been actuated by tolerant and statesmanlike motives in according such extensive privileges to his conquered subjects, he was also trying to solve a peculiar problem having its origin in the Moslem conception of the identity of the state and religion. The same laws, under this conception, could not apply equally to both Moslem and nonMoslem. The solution of the difficulty was simple and reasonable. If in certain respects Moslems may invoke from the authorities of the state the application. of Moslem law, then it follows that non-Moslems may likewise invoke the application of their own laws under similar circumstances. As the Ottoman authorities are not competent to administer such laws, the nonMoslems have the right to appeal to their religious heads, the Millet Bashi. The latter thus become, in a sense, political authorities acting in place of the Ottoman authorities, and to that extent are to be considered as heads of their respective "nations." While this has

kafir-kitabi, c'est-à-dire ceux 'dont la religion est contenue dans un livre.' Les premiers 'n'ont d'autre alternative que de croire ou de mourir; les autres sont admis, et faisant leur soumission aux Musulmans victorieux, à conserver, sous le nom de zimmis et plus tard, sous celui de rayahs, leur vie, leurs biens et mème leur religion, ainsi que tout ce qui, dans leur organization, leurs moeurs, leurs coutumes et leurs lois, était, aux yeux des Arabes, inséparable de la religion.'

Les Sultans Osmanlis ne firent pas autre chose qu'appliquer ces regles lorsqu'ils eurent renversé l'Empire byzantin. Etant kafir-kitabi, les rayahs ne pouvaient être traités en esclaves. Il fallait se borner à exiger d'eux un tribut. Il fallait aussi, pour tous les cas où ils ne seraient pas mis sur le même pied que les Musulmans, leur donner une loi speciale ou leur permettre se régir suivant leurs lois propres." 
created some embarrassments for the Turkish authorities, they have at the same time been relieved of the more embarrassing obligation of assuming jurisdiction in matters foreign to Moslem law and usage. The solution of the problem reached by Sultan Mohammed in granting immunities of jurisdiction to his non-Moslem subjects may therefore be considered on the whole as wise and satisfactory.

What were precisely the immunities of jurisdiction to be enjoyed by these communities; and just what relation these national organizations should bear to the Porte, are questions which have given rise to much controversy. The essential fact to be noted is simply that the Turks in the midst of a great triumph spontaneously and generously recognized the right of the conquered to be governed by their own laws and customs in matters held sacred by the Moslems, as well as in matters not of vital concern to the state.

It is evident then that this tolerant policy was in no way antagonistic to the spirit or the letter of Islam. It was, in fact, in entire harmony with the Moslem system of jurisprudence, and eloquently refutes the universal reputation for intolerance so unjustly attributed to the Turks. This policy, moreover, was in harmony with the generally recognized practice of nations at that time. Christian and Moslem rulers as we have seen, were already accustomed to accord to the subjects of each other reciprocal privileges of an exterritorial character. It likewise had been the practice of Mohammedan conquerors very much as the English 
have done in India $^{56}$ to leave the subjugated races in the fullest enjoyment of their own laws, whether in Sicily under the Arabs ${ }^{57}$ or Spain under the Moors. ${ }^{58}$

Whatever may have been the reasons and motives guiding the Ottoman Turks in their policy towards their non-Moslem subjects, whether of tolerance, statesmanship, or practical necessity, it is sufficient for the purpose of determining the origin and nature of the exterritorial privileges of foreigners in Turkey, simply to note in this connection that, without the aid of powerful armies or battleships, the Christians and other subjects of the Sultan received extensive immunities of jurisdiction resembling in certain respects those subsequently granted to foreigners.

56 Holland, op. cit., p. $40 \mathrm{I}$.

${ }^{57}$ Qui Siciliam, Sardiniam, Corsicamque incolebant populi Christiani tempore, quo Arabes insulas illas occuparent, Graecorum, quorum tum parebant imperio, jure utebantur. Cujus juris fundamentum illi legum codices erant, quos imperator Justinianu, Triboniani maxima opera, condiderat, etc. Johann Geor. Wenrich, Rerum ab Arabis in Italia, etc. p. 280.

${ }^{58}$ According to S. P. Scott in his History of the Moorish Empire in Europe (p. 265) the Moors respected the ancient laws and usages in Spain as far as was consistent with public policy. 


\section{THE CAPITULATIONS}





\section{CHAPTER II \\ The Capitulations}

Having noted the policy of Sultan Mohammed towards his non-Moslem subjects, we may now turn to the consideration of the privileges accorded by that Monarch to foreigners residing within his newly acquired dominions.

Reference has already been made to the fact that a few days after the capture of Constantinople on May 29, I453, Mohammed confirmed the exterritorial privileges previously enjoyed by the Genoese of Galata under the Greek Emperors. As the first formal statement of the policy regarding foreigners subsequently followed by the Turks with almost unvarying consistency, the charter ${ }^{1}$ of rights granted to the Genoese is of particular interest. It runs in part as follows: "I, the Great Seigneur, the Great Emir, Mohammed Bey, etc., etc., . . . I swear by God the creator of the heavens . . by the seven variants of the Koran which we confess, etc., . . . that $I$ concede to the inhabitants of Galata their laie's and franchises. . . The walls of Galata shall be razed; but the inhabitants shall preserve their goods, houses, shops, vineyards, mills, ships, boats, women, and their children. . . . They shall retain their churches and their hymns; but it shall be forbidden

${ }^{1}$ Joseph von Hammer, Geschichte des Osmanischer Reichs, vol. I, pp. $675-678$. 
them to ring the bells, etc., etc." Thus, while Galata ceased to exist as an independent municipality, its inhabitants retained the right to choose their own magistrates and settle their differences accordling to Genoese laws and customs.

It is of special interest to note that the political and commercial privileges conceded to the inhabitants of Galata were quite analogous to those granted to the merchants of Genoa by the Sultan of Egypt in I 290. ${ }^{2}$ In other words, the confirmation by Sultan Mohammed of the ancient privileges enjoyed by the Genoese under the Greek Emperors, was not merely a special, isolated act of a novel character, or the recognition simply of an old custom which the Turks by reason of their reverence for custom in general might have felt constrained to recognize. It was rather the acknowledgment of the general practice of the times,- - a conformity to the accepted rules of international intercourse.

This charter of rights, however, was of a municipal character rather than an international obligation, being a grant, not to a foreign nation, but to certain foreigners residing within Turkish dominions. The treaty of peace concluded at Adrianople April I5, I454, between Venice and Sultan Mohammed, on the other hand, was a formal international agreement of a reciprocal nature. ${ }^{3}$ As the precursor, if not the prototype, of those later agreements between Turkey and other

${ }^{2}$ Miltitz, op. cit., II, ch. I, sec. III, art. I, p. Iog.

${ }^{3}$ Pierre Daru, Historia della Republica di Venezia, libro XVI, sec. XV, p. 28I. 
nations, commonly termed Capitulations, ${ }^{4}$ this compact is of importance and worthy of special consideration.

It should be remembered that the Venetians residing in their quarter along the Golden Horn in Stamboul, unlike the Genoese of Galata on the opposite shore, had been completely identified with the Greeks in a common resistance to the Turks, and consequently had suffered severe penalties on the capture of the city, the chief Venetian magistrate having been decapitated and many Venetian nobles thrown into prison. ${ }^{5}$ The treaty of Adrianople ${ }^{6}$ while of general import as regarding the commercial and other interests of Venice, aimed

${ }^{4} \mathrm{~A}$ forced significance has been given to the term Capitulation as if it implied the submission of unbelievers to the Moslem Caliph in order to obtain peace. This conception has some basis in the fact that Soulh, the Arabic word employed in the early Capitulations, means truce,- the cessation of war. But this can hardly be held to have any other import than peace in the general sense, as employed in many treaties of peace, amity, and commerce, which signify, not the conclusion of war, but the agreement of two nations to live at peace with each other. Baron de Testa, in his Receuil des Traités etc. (vol. I, p. 6), asserts that the correct word for Capitulation is Ahd-nameh, meaning "letters of privilege." This seems entirely logical inasmuch as the early Capitulations were in the form of a grant, or charter of privileges accorded to foreigners by the Sultans. The fact that these privileges were set forth under various headings (caput, capitula), as statutes, or ordinances, gave rise to the vernacular use of the term Capitulations, which in the ordinary acceptance of the word as originally employed by the Italians, viz., capitulazione, meant nothing more than a convention, an agreement expressing in orderly form the various stipulations agreed upon. See also, Belin, Des Capitulations et des Traités de la France en Orient, p. 9.

${ }^{5}$ Miltitz, vol. II, p. 73; Daru, op. cit., libro XVI, p. 277.

${ }^{6}$ Daru, libro XVI, sec. XIV, pp. 28I-286. 
particularly to determine the status of Venetians residing in Turkey. Among its many provisions were included one for the mutual rendition of criminals; another for the custody and settlement by the Venetian Consul (Bailo) of the estates of Venetians dying intestate or without heirs; and also a unique agreement on the part of the Sultan to make indemnification for Venetian property destroyed during the capture and occupation of Constantinople. ${ }^{7}$

A provision calling for special mention is one fixing a duty of 2 per cent on all goods sold by Venetians in Turkish ports. In thus including import duties in a solemn treaty agreement, Turkey brought on itself in the course of centuries a most unfortunate situation, such that it cannot today change its customs tariff without first obtaining the consent of all nations with whom it has treaties. As this consent in each case can only be obtained as a rule by the concession of a substantial quid pro quo, a virtual servitude of a singularly harsh nature was thus innocently established by these early treaties of the Porte.

The provision of the Venetian treaty of 1454 which is pertinent to our present investigation reads as follows : ${ }^{8}$

... the Signoria of Venice may freely send to Constantinople a Bailo, together with his suite according to usage, who is free to rule in a cizil capacity and goz'ern,

'Ibid.; Che il Gran Signore si obbliga a ristorare tutti i danni si nell'avere che nella persona patiti per opera di Turchi da Veneziani nella presa di Constantinopoli, purche idoneamente provati.

8 Ibid., p. 285. 
and administer justice between Venetians of all classes, the Sultan obligating himself to require the Pasha, or Serasker (chief military officer) of Roumelia to grant every assistance to the Bailo, whenever requested, for the carrying on of his functions.

Here again we have not only a confirmation of ancient privileges, but also a further recognition of universal practice by the Turks. The Venetians had previously obtained quite similar privileges in 1238 from the Sultan of Egypt, Melek-el-Adel. But of greater interest is the fact that Aladin, the Turkish Sultan of Konia, entered into a treaty agreement of a reciprocal character with the Venetians in I2I9, whereby nationals of the one party enjoyed in the dominions of the other immunities of jurisdiction in all matters not of a criminal nature. ${ }^{9}$

Thus, the exigencies of Moslem jurisprudence, respect for the ancient usage of the Greek Empire as well as that of the Turks themselves, and respect for the generally accepted rules of international intercourse; all combined to induce Sultan Mohammed to grant by this treaty of 1454 with Venice exterritorial

${ }^{9}$ The provision of this treaty conceding the immunities mentioned, is given by Carlo Antonio Marin in his Storia civile .e politica del commercio de Veneziani as follows: "Se nascesse litigio tra Veneto ed un d'altro nazione,-Latinorum, Pisanorum e aliarum gentium cioe d'ogni altra nazione che non fosse Latina, dovra esso litigio esser giudicato dai piu probi tra i Veneti, excepta plaga gladii, \& excepto latrocinio, vale a dire $\mathbf{i}$ delitti criminali, i quali esser denno giudicata dal Soldano, e dalla sua Corte.

Dall altro cauto il Despota Tiepolo (then Ambassador) prometta al Soldano a nome del Doge di osservare del Veneto stato e giurisdizione le stessissima condizione." 
privileges which with slight variations have persisted through the different Capitulations between the Porte and the separate Italian States until this present day.

While the Genoese charter of rights of 1453 , and the Venetian treaty of 1454 decicled in principle the attitude of the Turks towards foreigners, and were the precursors of other treaties on the subject, it was not until the first part of the sixteenth century that the definite foundation stones of the régime of the Capitulations were laid.

In the year I528, Sultan Soliman II formally confirmed the privileges long enjoyed by the French and Catalan merchants established at Alexandria, Egypt. This charter of rights prescribed principally the rules to be observed in all commercial transactions; but as a necessary guarantee for complete freedom of trade, it also prescribed the special immunities of jurisdiction of the merchants concerned, as well as the privileges of the consuls. In addition to a general guarantee from hindrance and annoyance, these Capitulations defined the juriclical status of the merchants as follows $:^{10}$

If any difference should arise between Franks ${ }^{11}$ and Catalans, the Consul should decide, unless, however, there may have been shedding of blood, in which case our chief officials (presidens) shall try the case. . . And in conclusion, in all their acts and negotiations, that they should proceed in the ancient a'ay's without innovation of any sort, etc., etc. . . In conformity with which we command that all that is here above written be conceded to the

${ }^{10}$ Ancien Diplomat, p. 49; Miltitz, II, bk. II, p. 208.

${ }^{11}$ The word currently employed in Turkish to designate all Europeans is Efrenji, an obvious corruption of Frank. 
nations of the Franks and of the Catalans and other nations under the jurisdiction of their consul.

The quaint phraseology of this old document, as well as the absence of data showing exactly what were the "ancient ways" of carrying on business in Alexandria, leaves some uncertainty as to the full scope of the immunities granted. Judging, however, by other similar Capitulations of the Sultans of Egypt with Pisa and Florence, it may be presumed that the merchants of France, Catalonia, and other nations, were quite free to govern themselves and settle their own differences without any interference on the part of the local authorities. Nothing is indicated as to how differences between natives and the merchants were judged.

More definite, complete, and formal were the solemn treaty engagements ${ }^{12}$ of Sultan Soliman in I 535 with Francis First of France, who, from the time he was a prisoner in the hands of Charles the Fifth, had labored to bring about an alliance with the Turk against their common abhorred enemy, the House of Hapsburg.

This general treaty of peace, amity, and commerce may be considered as the real commencement of the régime of the Capitulations whereby foreigners in Turkey have come to enjoy such extraordinary privileges. Certainly all subsequent treaties were closely modelled on this treaty; and other nations have claimed as favorable treatment as therein accorded to France. In fact, it is stated in the body of this compact that the King of France reserved the right on behalf of the 12 Ancien Diplomat, pp. 60-66. 
Pope, the King of England, and the King of Scotland, to allhere to the treaty should they so desire. ${ }^{13}$

It is of fundamental importance, therefore, to consider briefly the specific provisions of this epoch-making document which determined the juridical status of the French and other foreigners within the dominions of the Grand Seigneur.

Article III. . . . whenever the King shall send to Constantinople or to Pera or other places in this Empire a magistrate (Baille), just as he has at present a Consul at Alexandria, said magistrates and Consul should be received and maintained in authority, in a fitting manner, and according to their Faith and law, without that any judge, Cadi, Soubashi, or other officials should intervene in, hear, judge or decide, whether in civil or criminal matters, any lazisuits, trials, or disputes, which may arise between merchants and other subjects of the King. But in case the orders and decisions of said magistrates and consuls should not be obeyed, and they should need the Soubashi or other officers of the Grand Seigneur in order to carry out their orders and decisions, the said Soubashi and other officers needed, should give their help and the force necessary. Nor may the Cadis or other officers of the Grand Seigneur judge any disputes of said merchants and subjects of the King, even though said merchants should so request; and if by chance said Cadis should judge, their decisions should be of no effect.

This article is so explicit and comprehensive as to require no special comment. It is of interest, how-

${ }^{13}$ Le Roy de France a nommé la Sainteté du Pape, le Roy d'Angleterre son frère et perpétual confédéré, et le Roy d'Ecosse, ausquels se laisse en eux d'entrer au present traité de paix, si bon leur semble, avec condition que, y voulans entrer, soient tenuz dans huict mois envoyer au Grand Seigneur leur ratification et prendre la sienne. (Quoted from text of Ancien Diplomat, p. 66.) 
ever, to note in this connection that until the latter part of the nineteenth century the Porte claimed no jurisdiction whatsoever, either in criminal or civil suits, between foreigners of different nationalities; and that it never has claimed jurisdiction in suits involving foreigners of the same nationality.

Article IV. . . . the merchants and subjects of the King may not be summoned, molested, nor judged, in a civil suit against Turks or other subjects of the Grand Seigneur, unless said Turks, Kharadjis, or other subjects of the Grand Seigneur present something in writing from the hand of the accuser, or formal document from the Cadi, magistrate (Baille), or consul; when such a paper is not presented, no testimony of any Turk or anyone else will be of value or accepted in any part of the dominions of the Grand Seigneur; and the Cadis, police officers, and other officials may not try or judge said subjects of the King without the presence of their dragoman.

While this article is not clearly worded, its purpose was to guard against false accusations and illegal suits devised to annoy or thwart any Frank trying to secure justice through the agency of Turkish judicial procedure. It probably could not have been realized at the time the treaty was signed that the presence at the trial, of the official interpreter of the consulate of the foreigner party to a suit, would transform that official in the process of time into a kind of judge without whose signature and assent no sentence would be strictly considered as of legal value. ${ }^{14}$

Article V. . . said merchants and other subjects of the King may not be summoned by the Turks or other

${ }^{14}$ Du Rausas, op. cit., vol. I, pp. 437-440. 
subjects of the Grand Seigneur, in criminal suits, before the Cadis or other officials of the Grand Seigneur and said Cadis and officials may not judge them; they should thus send them immediately to the Sublime Porte, and in default of said Porte, to the principal representative of the Grand Seigneur where the testimony of the subject of the King and of the Turkish subject against each other shall be (duly) weighed. ${ }^{15}$

The effect of this provision was to remove all cases involving life and liberty of foreigners from the jurisdiction of Ottoman courts and to submit them to settlement through diplomatic negotiations with the Sublime Porte. This cumbrous, non-judicial method of procedure became in time most unsatisfactory, and early in the nineteenth century the consular courts assumed jurisdiction over their nationals charged with crimes against Ottoman subjects. After the judicial and other reforms of the year 1856 , however, the rights of jurisdiction of Ottoman courts in such cases were conceded by the Powers, with the important restriction requiring the presence of the dragoman of the consulate of the accused, together with the virtual right of review of the decision by his consular or diplomatic representative.

15 The significance of this reference to the weighing of testimony lies in the fact that the testimony of Christians in ordinary Moslem courts was not held of equal value with that of a "true believer." The Sublime Porte, in treating such cases through diplomatic, extra-judicial negotiations, was able thus to give proper weight to the testimony of a Christian. It was not until 1854 , that by Imperial decree dated March 16 , "the testimony of Christians in criminal matters against or in favor of Mohammedans, was declared admissible." See Van Dyck's report, pt. I, p. 76 . 
Other provisions of the treaty of $\mathrm{I} 535$ relating to freedom of religious belief and worship, to exemption from taxation, to the settlement of the estates of those dying intestate or without heirs, and to such kindred subjects, are of no slight interest, but are not germane, however, to the subject in hand.

Owing to the Turkish theory that a treaty could have force only during the life of the Sultan who signed it, as a kind of modus vivendi or temporary truce with unbelievers (soulh), the Capitulations of $\mathrm{I} 535$ were subjected to numerous alterations of a sweeping character at the time of every new confirmation by successive Sultans. It was not until I 740 that these treaty rights were made perpetual, and hence not subject to further emendation.

It would be interesting and profitable to consider the various diplomatic negotiations connected with each renewal of the Capitulations between $\mathrm{I} 535$ and I740; to note the rivalries of the various Powers to obtain preeminence and special privileges in the Levant; to study the evolution of these early conventions from mere commercial agreements with attendant safeguards for freedom of commerce, into compacts granting to foreign nations and their nationals exceptional privileges not strictly necessary to freedom of trade. It would be especially of interest to study in detail the evolution of certain doubtful immunities of jurisdiction which have been claimed, and more or less successfully maintained by foreigners in Turkey. The scope of the present investigation, however, does not permit, nor 
(loes it perhaps require so extended an historical treatment of the subject. While a clear understanding of the origin of the Capitulations is necessary to a clear understanding of the juridical status of foreigners in the Ottoman Empire, the main object in view is to determine the precise immunities of jurisdiction actually guaranteed through treaties or through prescription, if, in fact, any prescriptive rights should have arisen.

Inasmuch as the Capitulations of I 740 are the legal basis, not only of French rights, but indirectly of the rights claimed by all other foreigners, it is important to examine scriatim the principal provisions of that treaty relating to immunities of jurisdiction.

By way of general comment, it should be observed that the treaty ${ }^{16}$ of $I 740$ is of the form properly termed Capitulations, containing, as it does, eighty-five articles (capitula) resembling ordinances, which together with the elaborate preamble embrace a great range of subjects. Among these are detailed regulations governing commercial intercourse, provisions defining the rights of merchant vessels, and others relating to the commercial privileges of consuls, as well as to the special prerogatives of ambassadors.

The articles which set forth the juridical rights of French subjects and, through the most-favored-nation clause, the rights of other foreigners are as follows :

Article I5. If a murder or other disorder should occur between Frenchmen, their ambassadors and consuls shall give judgment according to their usages and customs, without molestation in this regard by any of our officials.

${ }^{16}$ Ancien Diplomat, pp. I5O-182. 
Article 26. If any of our subjects should have a dispute with a French merchant, and they should refer it to the Cadi, said judge will not entertain the suit, if the French dragoman is not present; and if said interpreter is busy at that time with some pressing affair, they shall wait until he should come; but the Frenchmen will also hasten to produce him, without abusing the pretext of the absence of their dragoman. And if any difference should arise between French subjects, the ambassadors and consuls shall have jurisdiction, and shall give judgment according to their usages and customs zithout hindrance from anybody.

Article 29. We also confirm to the French all that is contained in the Imperial Capitulations accorded to the Venetians; and forbid all persons from opposing by any obstacle, suit, or trickery, the course of justice and the execution of my Imperial Capitulations.

Article 4I. Suits exceeding four thousand aspres shall be judged by my Imperial Divan (the Porte) and nowhere else.

Article 52. If it should happen that the French Consuls and merchants should have any disputes with the consuls and merchants of another Christian nation, they shall be permitted with the consent and at the demand of the parties (to the suit), to have recourse to their ambassadors who reside near my Sublime Porte: and as long as the plaintiff and the defendant shall not consent to bring such suits before the Pashas, Cadis, officials, or customs officers, the latter (authorities) shall not compel them to do so, nor presume to take cognizance of same.

Article 65. If a Frenchman or a protégé of France commit a murder or some other crime, and it is desired that justice be had in the case, the judges and officers of my Empire shall proceed in the matter only in the presence of the ambassador and consuls, or of their deputies in the places where they may be found; and in order that they should do nothing contrary to elevated justice or 
to the Imperial Capitulations, the necessary search and investigation shall be made with care by both parties.

Article 66. When one of our subjects, whether a merchant or otherwise, shall possess letters of exchange on Frenchmen, if those on whom they are drawn or the responsible persons do not accept them, it shall not be permitted without true cause, to compel them to pay said letters, and merely a letter of protest shall be required, in order to act thereupon against the drawer, and the ambassador as well as the consuls shall do everything possible to obtain reimbursement.

Article 7o. The officers of justice as well as the military officials (police) may not, without necessity, enter by force a house inhabited by a Frenchman; and when the situation requires that it be entered, they shall notify the ambassador or the consul in the localities where they may be found, and he shall be taken to the place in question with the persons involved; and if anyone violates this provision he shall be punished.

Articles $7 \mathrm{I}$ and 72 which are too lengthy and discursive to quote here, provide against any possible abuses in the way of judicial persecutions of Frenchmen and natives without the cognizance and consent of the ambassador or consul, as well as of the Sublime Porte.

Such are the principal provisions of the Capitulations of 1740 , on which rest the claims of the French and of nearly all other foreigners to the extensive immunities of jurisdiction they today enjoy in Turkey. There are other articles of the treaty relating to these immunities; but as their effect is to guarantee the faithful execution of the principal stipulations, they do not warrant for our purpose special consideration.

Through tenacious insistence on the right to the same treatment accorded to the most favored nation, the 
other nations have successively obtained from Turkey for the benefit of their own nationals the same privileges granted to France in the Capitulations of I 535 and 1740 as confirmed by subsequent treaties. ${ }^{17}$ England was the first, in the year I $_{579}$; Holland also in the same year; Austria in I6I5; Russia in I7II ; Sweden in 1737 ; Denmark in I756; Prussia in 1761 ; Spain in I782; Sardinia in I825; the United States in I830; Belgium in 1838 ; Portugal in I843; Greece in 1854 ; Brazil in 1858 , etc. ${ }^{18}$ Most of these treaties were later modified; by extension in some instances, by restrictions in others. But in general it may be said that France first obtained for the rest the main immunities of jurisdiction claimed by all the Powers in subsequent treaties; and that all, through the most-favored-nation clause, secured the mutual benefit of those special privileges obtained by any individual nation. For example, Article IV of the treaty between Turkey and the United States, which led to rather extreme claims of jurisdiction on the part of the latter (as will be shown further on),$^{18^{a}}$ offers a precedent though perhaps a poor one on which other nations might found similar claims.

17 Van Dyck's Report, pt. I, pp. 15-23.

18 The Arbitral Award of the Ambassadors of the six Powers, signed March 20, 190I, in respect to the rights of Greek subjects in Turkey after the war of 1897 , confirmed the rights of foreigners, in the main, though it made some concessions to the Turks by restricting slightly the privileges enjoyed by the Greeks before their disastrous trial at arms with Turkey. See Journal de Droit International Privé, 1902, pp. 936-945. For analysis of this award, see article by Professor Politis in the Rev'ue generale de Droit International Public, 1903, p. 86.

${ }^{19^{a}}$ See page 76 infra. 
The whole régime of the Capitulations was subjected to a sweeping readjustment in 1867 through the promulgation of the law granting to foreigners the right to possess real estate. ${ }^{19}$ This readjustment was brought about by the fact that the concession of the right to hold land was made contingent on the consent of the foreigner to become completely subject to Ottoman jurisdiction and law in all that concerned ownership of real property.

Articles one and two of the Imperial rescript of the 7 th Sepher I 284 (January I6, I 867) are as follows : ${ }^{20}$

Foreigners are admitted to the same privilege as Ottoman subjects, and without any other restriction, to enjoy the right of holding Real Estate whether in the city or in the country, throughout the Empire, with the exception of the Province of the Hedjaz, ${ }^{21}$ by submitting themselves to the laws and regulations which govern Ottoman subjects, as is hereafter stated.

This arrangement does not concern subjects of Ottoman birth who have changed their nationality, who shall be governed in this matter by a special law. ${ }^{22}$

19. Van Dyck in his Report, part I, pp. 48-83, gives an excellent historical and critical review of the whole question of land ownership, and of the negotiations connected with the drawing up of the Protocol by which the Powers assented to the modifications of the Capitulations involved in the concession to foreigners to hold real estate subject to Ottoman law and jurisdiction.

${ }^{20}$ As given in Treaties, Conventions, etc., of the United States, pp. $13+H^{-1} 348$. This translation is awkward but it is quoted because official.

21 The Hedjaz district in Arabia was exempted for the reason that it contains the Moslem holy places of Mecca, Medina, et al., which may not be defiled by the presence of "unbelievers."

22 The object of this clause was to discourage the naturaliza- 
Foreigners, proprietors of Real Estate in town or in country, are in consequence placed upon terms of equality with Ottoman subjects in all things that concern their landed property.

The legal effect of this equality is :

I. To oblige them to conform to all the laws and regulations of the police or of the muncipality which govern at present or may govern hereafter the enjoyment, the transmission, the alienation, and the hypothecation of landed property.

2. To pay all charges and taxes under whatever form or denomination they may be, that are levied, or may be levied hereafter, upon city or country property.

3. To render them directly amenable to the Ottoman civil tribunals in all questions relating to landlord (sic) property, and in all real actions, whether as plaintiffs or as defendants, even when either party is a foreigner. In short, they are in all things to hold Real Estate by the same title, on the same condition and under the same forms as Ottoman owners and without being able to avail themselves of their personal nationality, except under the reserve of the immunities attached to their persons and their movable goods, according to the treaties.

So violent a breach in the citadel of the Capitulations could not be effected by the mere fiat of the Sultan, laudable as it was in purpose. The submission of foreigners to Ottoman juriscliction and law to so sweeping; an extent could only be secured through the formal consent and sanction of the Powers. After prolonged diplomatic negotiations in which the Porte displayed

tion in foreign countries of Ottoman subjects whose allegiance has always been held to be inalienable except by the express consent of the Sultan. Moreover, it has been the constant aim of the Porte to prevent by every possible means any increase in the number of foreign protégés of whatever sort in Turkey with the attendant evils of diplomatic intervention derogatory to Turkish sovereign rights. See page 94 infra. 
great skill and won substantial concessions as a quid pro quo for granting the right to hold real estate, a protocol was drafted and agreed to by the principal Powers $^{\mathbf{2 3}}$ under the leadership of Monsieur Bourrée, the French Ambassador, defining the conditions under which foreigners should be subject to Ottoman laws and jurisdiction.

While this momentous agreement reaffirmed the immunities conferred by the Capitulations, and according to Monsieur Bourrée, was intended to apply so!ely to foreigners holding real estate, ${ }^{24}$ it did in fact make concessions which were in derogation of priviieges previously enjoyed by all foreigners. These concerned the right of local authorities, under certain conditions, to search the residences of foreigners which had hitherto been deemed inviolable. They concerned also the right of local tribunals to try certain cases without the presence and assistance of the consular representative of the foreigner party to the suit as formerly required under the Capitulations.

This Protocol is too lengthy to be quoted in full. but certain of its provisions should be noted in order that we may have clearly before us the exact modifi-

${ }^{23}$ Most of the Powers gave their consent to this important modification of exterritorial rights by authorizing their diplomatic representatives in Constantinople to sign the Protocol. The United States preferred to give the transaction the character of a formal, international convention signed under seal by duly authorized plenipotentiaries. The Protocol was formally proclaimed by the President on October 29, 1874, in accordance with the authorization of Congress expressly given by its Act of March 23, 1874. See U.S. Treaties, etc., pp. 1344-1346.

24 Van Dyck's Report, part I, p. 8I. 
cations of the Capitulations which were entailed by the admission of foreigners to equal rights with Ottoman subjects in the ownership of real estate. ${ }^{25}$

The law granting foreigners the right of holding real estate does not interfere with the immunities specified by the treaties, and which will continue to protect the person and the movable property of foreigners who may become owners of real estate. . . (Domicile.) The domicile of any person residing upon Ottoman soil being inviolable, and as no one can enter it without the consent of the owner, except by virtue of orders emanating from competent authority and with the assistance of the magistrate or functionary invested with the necessary powers, the residence of foreigners is inviolable on the same principle, in conformity with the treaties, and the agents of the public force cannot enter it without the assistance of the Consul or of the delegate of the Consul of the Power on which the foreigner depends.

By residence we understand the house of inhabitation and its dependencies: that is to say, the outhouses, courts, gardens and neighbouring enclosures, to the exclusion of all other parts of the property. ${ }^{26}$

In the localities distant by nine hours or more than nine hours of travel from the residence of the Consular Agent, the agents of the public force may on the request of the local authority . . . enter into the residence of a foreigner, without being assisted by the Consular Agent, but only in case of urgency, and for search and proof of

${ }^{25} U$. S. Treaties, etc., pp. 1344-1346.

${ }^{26}$ The inviolability of the domicile of foreigners arose from their original custom of permitting them to reside in their own quarters under the separate jurisdiction of their own officials as in the case of the Genoese and Venetians in Constantinople. When, in the process of time, foreigners began to reside outside of these quarters, they were allowed to carry with them the same privileges. In other words, the domicile of the Genoese or Venetian was treated as national territory just as the quarter formerly assigned to his nationality. It is easy to see how naturally the term exterritoriality came into use when applied in this sense. See Du Rausas, I, p. 87. See page 90 infra. 
the crime of murder, of attempt at murder; of incendiarism, of armed robbery either with infraction (sic) or by night in an inhabited house, of armed rebellion and of the fabrication of counterfeit money, and this entry may be made whether the crime was committed by a foreigner or by an Ottoman subject, and whether it took place in the residence of a foreigner or not in his residence, or in any other place. ...

Beyond the residence, the action of the police shall be exercised freely and without reserve; but in case a person charged with crime or offence, should be arrested, and the accused shall be a foreigner, the immunities attached to his person shall be observed in respect to him. . . .

(Jurisdiction of local tribunals.) In localities more distant than nine hours' travel from the residence of the Consular Agent, in which the law of the judicial organization of the Vilayet (province) may be in force, foreigners shall be tried, without the assistance of the Consular delegate by the Council of Elders fulfilling the function of justices of the peace, and by the tribunal of the canton, as well for actions not exceeding one thousand piasters as for offences entailing a fine of five hundred piasters only, at the maximum.

Foreigners shall have, in any case, the right of appeal to the tribunal of the Arrondissement (Caza) against the judgments issued as above stated, and the appeal shall be followed and judged with the assistance of the Consul, in conformity with the treaties. The appeal shall always suspend the execution of a sentence.

In all cases the forcible execution of the judgments, issued on the conditions determined heretofore, shall not take place without the coopperation of the Consul or of his delegate. . . .

Foreigners, in whatever locality they may be, may freely submit themselves to the jurisdiction of the Council of Elders or of the tribunal of the canton without the assistance of the Consul in cases which do not exceed the competency of these councils or tribunals, reserving always the right of appeal before the tribunal of the Arrondissement, where the case may be 
brought and tried with the assistance of his Consul or his delegate. ... .

It is well understood that all these restrictions do not concern cases which have for their object questions of real estate, which shall be tried and determined under the conditions established by the law.

The right of defence and the publicity of the hearings shall be assured in all cases to foreigners who may appear before the Ottoman tribunals, as well as to Ottoman subjects.

The preceding dispositions shall remain in force until the revision of the ancient treaties, - a revision which the Sublime Porte reserves to itself the right to bring aboui hereafter by an understanding between it and the friendly powers.

It is clear that the concessions included in the above quoted provisions of the Protocol governing the submission of foreigners holding real estate to Ottoman jurisdiction constituted a serious weakening of the whole fabric of the Capitulations, while demonstrating incidentally the insufficiency of the fiction of exterritoriality as an explanation of privileges which, strictly speaking, are immunities of jurisdiction that may be considerably restricted from time to time by mutual agreement.

Having thus briefly reviewed the historical development of the Capitulations, and noted their principal provisions governing the juridical rights of foreigners, we may next proceed to endeavor to reduce to the compass of a simple code these rights as recognized in practice or claimed in theory at the present time in Turkey. ${ }^{27}$

27 Egypt and Cyprus are not considered in this connection because they are only nominally Turkish territory and enjoy a special status under British rule. 

THE JURIDICAL RIGHTS OF FOREIGNERS 



\section{CHAPTER III}

The Juridical Rights of Foreigners

In attempting to reduce to the limits of a definite corle the recognized or asserted rights of foreigners in Turkey, it is necessary to bear in mind that these rights do not rest in the case of each nationality on any single treaty. If this were so, the task would be relatively simple. As has been already pointed out (page 4I), those rights which were originally based on the French Capitulations of $\mathrm{I} 535$ and $\mathrm{I} 74 \mathrm{O}$, in the process of time, have been extended or restricted by other treaties or protocols, as well as by varying interpretations accepted in different cases arising between the Powers and the Porte. Usage also plays no little part in determining the rights of foreigners. Our object must be to try to determine clearly: first those rights which are not disputed, and second, those rights which, though questioned, may have the sanction of long usage.

The subject may best be considered uncler the following aspects: (I) immunities of jurisdiction in cases involving foreigners of the same nationality; (2) in cases concerning foreigners of lifferent nationality; and (3) in cases between foreigners and Ottoman subjects. In each instance the principal points to be considered are: ( I) the nature of the rights involved; 
(2) the kind of tribunals and judicial procedure employed; (3) the law to be applied; and (4) the execution of the law.

A. imMunities of JURisdiction in CASES Involving FOREIGNERS OF THE SAME NATIONALITY ${ }^{1}$

I. Consular tribunals have absolute jurisdiction in cases involwing foreigners of the same nationality. ${ }^{2}$

This sweeping immunity of jurisdiction has been consecrated by all the Capitulations since the charter of rights granted to the Genoese of Galata by Mohammed the Conqueror in I453. It has never been questioned by the Porte, even in cases which directly concerned the state in the maintenance of public order. If one foreigner murders another of the same nationality, he may be tried and punished only by his own consular court.

There are, however, certain exceptions to the rule

1 The material for this chapter has been drawi mainly from Le Régime des Capitulations by Pclissic du Rausas, head of the French Law School in Cairo, and from La Justice Ottomane, by André Mandelstam, formerly Dragoman of the Russian Embassy in Constantinople. The former work is a most exhaustive, analytical study of the whole subject. The latter is the latest, and perhaps the most authoritative book in regard to actual usage and practice in Turkey respecting the juridical rights of foreigners. The writer is under particular obligation to Mr. Mandelstam both as to form and substance in the preparation of this volume.

2 Mandelstam, pp. 213-224; Du Rausas, pp. 219-393. See page supra, for text of Article 15 of the French Capitulations of 1740 , on which this right is based. 
stated above. First, as previously indicated, foreigners are subject to Ottoman law and jurisdiction in all matters relating to the ownership of real estate. ${ }^{3}$ The question of inheritance, however, as in all matters involving questions of personal status, may properly come before a consular tribunal in order to determine who are the legal heirs entitled to inherit property of a deceased foreigner. The Porte has endeavored to extend Ottoman jurisdiction in property matters so as to cover disputes as to rent. This contention has not been admitted by the Powers. Such cases are regarded by them as of like nature to any other contracts between foreigners of the same nationality, and hence justiciable in a consular court.

Another question of like nature is that of mortgages. It is recognized that anything relating to the sale or transfer of mortgaged property is entirely within the province of Ottoman tribunals. But if the point at issue is merely the payment of interest in compliance with the terms of the mortgage, namely, the carrying out of a contract, this is claimed by the Powers to be within the competence of the consular court of the parties concerned. ${ }^{4}$

The Porte has claimed that all suits relating to the falsification of trademarks are within the competence

${ }^{3}$ Du Rausas, pp. 414-466. See also page 42 supra.

${ }^{4}$ Mandelstam, p. II9. See the same work (pp. ini-i38) for detailed discussion regarding the conflicts between the Powers and the Porte over the interpretation of the law and protocol of 1867 in respect to jurisdiction in questions involving ownership of real estate. 
of Ottoman tribunals alone; but this has not been formally conceded by the Powers. ${ }^{5}$

It has been noted that foreigners of their own free will may have recourse to Ottoman courts if they so prefer. ${ }^{j^{n}}$ Such a procedlure, however, as a matter of fact, is not countenanced by the Powers except in suits involving less than a thousand piasters $(\$ 44.00)$, in localities distant more than nine hours from the consular agent of the foreigners party to the suit."

\section{Courts and Procedure}

Consular courts vary greatly in form and procedure. England ${ }^{7}$ and Austria-Hungary, for example, both maintain supreme courts at Constantinople with powers of original juriscliction as well as of appeal. The United States, however, has no formal tribunal, the Consul acting as judge without any legal ceremonies or complicated procedure. The principal provisions of the United States Statutes for the organization

5 Mandelstam, p. 223.

$5^{\text {a }}$ See article 52 of treaty of 1740 , page 39 supra; also page 46.

${ }^{6}$ Ibid., p. $2 \mathrm{I} 4$. A curious conflict of jurisdiction exists between certain of the Patriarchs in Constantinople and the Powers, the former claiming the right to judge in matters relating to personal status between foreigners owing spiritual allegiance to the respective Patriarchates. Thus it is entirely possible that two Armenians, who may have been naturalized in the United States, might submit for the decision of the Armenian Patriarch a question relating to divorce or inheritance. See Mandelstam, p. 219.

7 For powers and jurisdiction of British courts in Turkey see Hall, Forcign Jurisdiction of the British Crown, chapter II; Young, op. cit., I, pp. 279-284. 
and procedure of Consular Courts as set forth in the Instructions to the Diplomatic Officers of the United States, are as follows: ${ }^{8}$

2I4. Criminal Jurisdiction.-Consuls . . . are empowered to arraign and try all citizens of the United States charged with offences against law, committed in such countries, respectively (China, Siam, Turkey, etc.), and to sentence such offenders in the manner therein authorized, and to issue all processes as are suitable and necessary to carry this authority into execution.-R. S., secs. $4084,4087$.

2I5. Civil Jurisdiction.-Consuls are invested with all the judicial authority necessary to execute the provisions of such treaties, respectively, in regard to civil rights, whether of property or person; and such jurisdiction embraces all controversies between citizens of the United States, or others, provided for by such treaties. ...-R. S., sec. 4085 .

220. Original Jurisdiction.-The power of commencing original civil and criminal proceedings is vested in consuls exclusively, except that capital cases for murder or insurrection against the government of the country in which they reside, by citizens of the United States, or offences against the public peace amounting to felony under the laws of the United States, should be tried before the Minister of the United States in the country where the offence is committed, if allowed jurisdiction; and except, also, that original jurisdiction is vested in said ministers respectively in cases where a consular officer shall happen to be interested as party or as witness.-R. S., secs. 4090, $4109 .^{9}$

${ }^{8}$ Instructions to the Diplomatic Officers of the United States, I897, pp. 79-98. The numbers prefixed indicate paragraphs. See also Wharton's International Law Digest, I, Sec. 125; Moore's International Law Digest, II, Sec. 262-266. The Regulations in force in the Consular Courts of the United States, in Turkey are given in the Appendix to this volume.

9 "The word 'minister' as used in Title XLVII of the Re- 
22r. Associates in Criminal Cases.-Whenever, in any case, the consul is of opinion that, by reason of the legal questions which may arise therein, assistance will be useful to him, or whenever he is of opinion that severer punishment than five hundred dollars fine or ninety days' imprisonment will be required, he shall summon to sit with him on the trial one or more citizens of the United States, not exceeding four, who shall be taken by lot from a list previously submitted to and approved by the minister and who sliall be persons of good repute and competent for duty. Every such associate shall enter upon the record his judgment and opinion and shall sign the same; but the consul shall give judgment in the case.-R. S., sec. 4106.

222. Capital Cases.--In trials for capital offenses there must be not less than four associates, who must all concur in opinion with the consul; and their opinion must be approved by the minister before there can be a conviction. But a person put upon trial for a capital offense may be convicted of a lesser offense of similar character.-R. S., secs. 4102, 4106.

223. Associates in Civil Cascs.-Whenever a consul is of opinion that any case involves legal perplexities and that assistance will be useful to him, or whenever the damages demanded exceed five hundred dollars, he shall summon to sit with him on the hearing of the case not less than two nor more than three citizens of the United States, who shall be taken from a list previously submitted to and approved by the minister and who shall be of good repute and competent for duty. Every such associate shall note upon the record his opinion, and also, in case he dissents from the consul, such reasons

vised Statutes means the person invested with and exercising the principal diplomatic functions. The word 'consul' means any person invested by the United States with and exercising the functions of consul-general, vice-consul-general, consul, or vice-consul.-R. S., sec. 4I30." (Paragraph 202 of Diplomatic Instructions.) 
therefor as he thinks proper to assign; but the consul shall give judgment in the case.-R. S., sec. 4I07.

227, 228. Settlement of Civil Cases and Minor Offenses.-These paragraphs on the instructions relate to sections 4098 and 4099 of the Revised Statutes which provide for the settlement out of court by arbitration, referee, etc., of controversies of a civil character, and criminal cases of minor importance, upon pecuniary or other considerations.

229. Forms of Proceedings.- (This paragraph relates to sections 4II7-4I2O of the Revised Statutes which provide for the drawing up and promulgation of rules and regulations by the minister with the advice of the several consuls in regard to the forms of processes to be issued by the consular courts, the manner in which the trials shall be conducted, fees, bail, etc., etc.)

233. Evidence.-In all cases, criminal and civil, the evidence shall be taken down in writing in open court under such regulations as may be made for that purpose; and all objections to the competency or character of testimony shall be noted, with the ruling in all such cases. The evidence so taken down shall be a part of the case.-R. S., sec. 4097.

234. Appeals to Minister.-The minister is authorized to hear and decide all cases, criminal and civil, which may come before him on appeal and to issue all processes necessary to execute the power conferred upon him; and he is fully empowered to decide finally any case upon the evidence which comes up with it or to hear the parties further if he thinks justice will be promoted thereby. He may also prescribe the rules upon which new trials may be granted, either by the consul or by himself, if asked upon sufficient grounds.-R. S., sec. 409I.

235. Appeals to Minister, when Allowed.-An appeal is allowed from the consul to the minister in the following cases: 
In civil cases-

(a) When the consul sits with associates and any of them differ from him. If no appeal is lawfully claimed, the decision shall be final.-R. S., sec. 4 IO 7.

(b) (In China and Japan.)

In criminal cases-

(a) When the consul sits with associates and any of them differ from him. The case shall be referred to the minister for his adjudication.-R. S., sec. 4 I06.

(b) When the consul sits alone and the fine exceeds one hundred dollars or the term of imprisonment for the misdemeanor exceeds sixty days. The appeal may be either upon errors of law or matters of fact.-R. R., sec. 4089 .

237. Judgments of Consuls Final.-The judgments of consuls are final in the following cases:

In civil cases-

(a) When the consul sits alone and the damages demanded do not exceed five hundred dollars.-R. S., sec. 4107.

(b) When the consul sits with associates and they concur with him. . . R. S., secs. 4092, 4107.

In criminal cases-

(a) When the consul sits alone and the fine does not exceed one hundred dollars or the term of imprisonment does not exceed sixty days.-R. S., sec. 4105.

(b) When the consul sits with associates and they concur with him, except in capital cases.-R. S., sec. 4 Io6.

It may be seen from these excerpts that the organization and procedure of the consular courts in Turkey is extremely simple with a view to meeting peculiar conditions and facilitating the administration of justice. ${ }^{10}$ In these respects, exterritorial jurisdiction has

${ }^{10}$ In Moore's International Law Digest (vol. II, sec. 263) are to be found the following observations in this connection. 
much to commend it in comparison with the jurisdiction of the home courts.

\section{Law Administered}

The laws enforced in the foreign judicial tribunals in Turkey are such as may be prescribed by the legislation of the various countries, and vary greatly in character and scope. Those of France ${ }^{11}$ are most elaborate and comprehensive, while those of the United States ${ }^{11^{a}}$ are very simple though adequate for their purpose. The chief provisions of the Revised Statutes in this respect, as indicated in the Instructions to the Diplomatic Officers of the United States, are as follows. ${ }^{12}$

“... Mr. Fish entered into a full discussion of the minister's power to make decrees and regulations, under section 5 and 6 of the act of June 22, I860. He described it as being 'confined to the course of procedure in pursuing judicial remedies, and as not extending to the creation of new rights or duties in citizens of the United States, or to the modification of personal rights and obligations under the existing laws,' and, with regard to the diversities in the common law arising from the complex Federal system in the United States, he expressed the opinion that it would be most discreet to allow the anomalous jurisdiction of our consular courts ... to find its limits and definition from the practical exigencies of administration and the acquiescence of the government within whose territory the jurisdiction is exercised.'"

The enormous latitude allowed to the jurisdiction of American consular courts in Turkey could not fail to give rise to a unique body of law and procedure having slight relation to that observed in the United States.

${ }^{11} \mathrm{Du}$ Rausas, pp. 308-332.

11* See Appendix for United States Rules, etc., for consular courts.

12 Diplomatic Instructions, p. 87. 
217. Jurisdiction, How Excrcised.-Juriscliction in both criminal and civil matters shall be exercised in conformity, first, with the laws of the United States; second, with the common law and the law of equity and admiralty; and third, with decrees and regulations, having the force of law, made by the ministers of the United States in each country, respectively, to supply defects and deficiencies when neither the common law, nor the law of equity or admiralty, nor the statutes of the United States furnish appropriate and sufficient remedies.-R. S., sec. 4086.

218. Power of Ministers to Make Regulations.-The authority of a minister to make regulations having the force of law within the country to which he is accredited is a judicial authority. The minister is required to execute the power in conformity with the laws of the United States, with authority to supply defects and deficiencies: (a) Where those laws are not adapted to the exercise of the judicial authority conferred by the statute; (b) where they are deficient in the provisions to furnish suitable remedies. (R.S., sec. 4086.) In each of these contingencies the minister has authority to make regulations in order "to furnish suitable and appropriate reme. dies," and for no other purpose whatever. Every power named in the statute in this respect is conferred upon the minister "in order to organize and carry into effect a system of jurisprudence." ..

Under the exterritorial theory respecting the status of foreigners in Turkey, they should only be subjected to those laws which are applicable to them within their native jurisdiction. As a matter of fact, however, acting in conformity with the Roman legal maxim locus regit actum, the consular courts frequently are influenced in their decisions by local usages and customs. This principle applies in such matters as marriage, in various commercial transactions, the organi- 
zation of special communities and corporations, and in general in the determination of the validity of juridical acts. Du Rausas goes so far as to affirm that:

The consular tribunals should refuse to approve any custom which might be in opposition with a law of public order inspired by motives of moral and social interest; but if the law of public order contradicted by the custom is inspired by political or economic motives, the consular tribunals should not hesitate to apply the custom. By way of résumé, custom has force of law in every case where it does not contradict a law of public order inspired by motives of moral or social import. ${ }^{13}$

It is clear that foreigners are not truly under the extraterritorial jurisdiction of their home laws. On the contrary, they may even be denied the benefit of their own laws, as illustrated by the fact that Americans, accused of crime before a United States Consular. Court in Turkey, may be indicted without a grand jury and tried without a petit jury. ${ }^{14}$

\section{Execution of Law}

As to the enforcement of law, the powers and functions of consuls vary widely. The police jurisdiction of French consuls ${ }^{15}$ over their own nationals is

${ }^{13} \mathrm{Du}$ Rausas, p. 318. The same author also states (p. 24I) that: "The rule 'locus regit actum' serves as universal law (droit commun) when it is a question of determining as to form the value of an act which took place in a foreign land. In order to discard the application of this universal law in the Ottoman Empire, a formal provision (texte) would be necessary. This provision does not exist either in French legislation, or in any other foreign legislation."

${ }^{14}$ Diplomatic Instructions, p. 83.

15 As to powers and jurisdiction of French consuls, see Du Rausas, pp. 243-263, 332-393. 
very great extending even to the right of expulsion. In earlier times a French consul exercised over his fellow countrymen a control closely resembling that of a governor of a conquered province. The police powers of the American consuls, on the other hand, are most limited being concerned with punitive rather than with preventive measures. ${ }^{16}$ In general, it may be said that, while theoretically foreigners are bound equally with natives to respect Ottoman laws and regulations, in actual practice they enjoy greater freedom than many of them would have in their native lands. This is due to the fact that Turkish police have learned by bitter experience that it is often unvise to interfere in any way with foreigners, and also that the police powers of consular authorities are insufficiently employed except in the case of gross infractions of the law.

The arrest of foreigners accused of crimes by other foreigners of the same nationality is usually effected by the marshals of the consular courts issuing the warrants of arrest. ${ }^{17}$ The native guards (Cavass) attached to every consulate may also make the arrest. ${ }^{18}$ In some instances the consular authorities may request the Ottoman officials to make the arrest, or the latter on their own initiative may arrest foreigners

16 The Consulate General in Constantinople is aided in its police work by a United States marshal duly appointed for the purpose.

17 Mandelstam, p. 176.

18 Van Dyck's Report, part I, pp. 96-99. 
flagrante delictu, and turn them over immediately to the competent consular representatives. ${ }^{19}$

In case there is no consular prison for the detention of such persons, it is customary to request their imprisonment in Turkish jails. This is undesirable from the point of view of the Turks who have to feed and care for prisoners in whom they have no interest. It is likewise undesirable from the point of view of the prisoner whose physical comforts are frequently neglected. ${ }^{20}$

After sentence has been pronounced by the consular tribunal, it is usual to remand the prisoner to the country of his allegiance, either for trial on appeal, or for the infliction of the penalty imposed. For minor offenses, the consular courts usually prefer to impose a fine rather than imprisonment with all its attendant inconveniences of maintaining a foreign prison in Turkey, or the expense and trouble of deportation.

For grave offenses, most of the Powers require final judgment by the home courts in case of appeal. Such a procedure has the obvious merit of taking from a consular court the extreme powers of indictment, trial, and judgment, without review by another tribunal.

The British, Greek, and American judicial procedure, while varying greatly in form, is based on the principle that the proper place for a trial is the forum delicti. Appeal in certain cases, both civil and criminal, is allowed from the British Supreme Court in

${ }^{19}$ Hall, Foreign Jurisdiction of the British Crown, section 69. ${ }^{20}$ Moore, Int. Law Digest, II, pp. 634, 677. 
Constantinople to the Privy Council in London; and the execution of the death penalty may not take place within Ottoman jurisdiction. ${ }^{21}$ Under the Revised Statutes, the American Ambassador in Constantinople is the final court of appeal except in cases involving the infliction of the death penalty. The procedure after conviction, as set forth in the Instructions to Diplomatic Officers, is as follows:

224. Punishments.-In the inflictions of punishments on persons convicted in consular courts, consular officers will be governed by the provisions of the statutes of the United States prescribed for similar offenses and will be careful that the sentence in each case is in conformity thereto. Consular courts have no power to banish American convicts to the United States or other countries, nor to send them to the United States, to serve out their terms of imprisonment.-I Whart. Int. L. Dig., p. 805 ; 14 Op. Att. Gen., 522 ; i9 Op. Att. Gen., 377.22

21 Hall, op. cit., pp. I69-I 70.

22 In regard to extradition Moore states (vol. II, p. 633): "With most countries it has been the rule to regard the recovery of their fugitive subjects, charged with ordinary crimes, as an incident of the extraterritorial jurisdiction exercised through their ministers or consuls. The United States, however, has not generally sought to enjoy this privilege, but has, on the other hand, in two cases-those of the Ottoman Empire in 1874 and Japan in 1876 -entered into treaties of extradition with the governments of countries in which citizens of the United States were entitled to extraterritoriality." Moore, however, points out that on two different occasions the United States has extradited citizens through the exercise of extraterritorial jurisdiction. John H. Suratt who was charged with complicity in the assassination of President Lincoln, was arrested in Alexandria, Egypt, in 1866, and sent to the United States in an American warship. Henry Myers and J. F. Tunstall of the Confederate cruiser Sumter were also seized at Tangiers and taken to the United States. 
225. Execution of Death Penalty.-The statutes provide that in case of a conviction entailing the death penalty, it shall be the duty of a minister to issue his warrant for the execution of the convict, appointing the time, place and manner; but if the minister is satisfied that the ends of public justice demand it, he may from time to time postpone such execution. If he finds mitigating circumstances which authorize it, he may submit the case to the President for pardon.-R. S., sec. 4103.

226. Requesting the President's Viezes.-As the provision of section 4103 of the Revised Statutes stands, it appears to make the diplomatic representative the sole judge of the propriety of extending Executive clemency to the convict. It was probably not the intent of C.ongress to bar the exercise of the President's power of pardon at the discretion of a diplomatic representative; and it would be manifestly improper, as well as of doubtful constitutionality, to do so in the possible case of conviction being had before the officer whose duty it is made to execute the sentence. In cases coming under this statutory provision, the Department of State deems it advisable that the diplomatic representative should always regard the ends of public justice as requiring postponement of the execution until the case is reported and copies of the judgment and testimony are transmitted to the Department of State and the President's views in the premises have been received. ${ }^{23}$

To summarize in a general way the immunities of jurisdiction in cases involving foreigners of the same nationality, it may be said that jurisdiction belongs

${ }^{23}$ In the case of Stephen P. Mirzan, an alleged American citizen who was accused of the murder of one Alexander Dahan in the streets of Alexandria, July 17, 1879, Minister Maynard tried Mirzan and sentenced him to be hanged. President Hayes commuted the sentence to imprisonment for life. President Arthur, in I882, directed that Mirzan be brought to Albany, New York, where he remained until released in 1889 . Moore's Digest, II, pp. 635, 683. 
exclusively to the consular tribunal of the parties concerned; that this tribunal follows such procedure as is prescribed by its government; that the law applied, while in the main that enforced in the home land, is not infrequently altered to harmonize with local customs and usages; and that the carrying out of the law, whether preventive or punitive, varies greatly according to the legislation of each country, being as a rule much less severe than would be the case if the same offenses had been committed in the countries to which those under conviction owe allegiance. ${ }^{24}$

B. IMMUNITIES OF JURISDICTION IN CASES INVOLVING FOREIGNERS OF DIFFERENT NATIONALITIES ${ }^{25}$

I. The consular tribunal of the defendant has jurisdiction in cases involving foreigners of different nationalities.

The Porte has never questioned the competence of consular tribunals to hear and decide civil suits between foreigners of different nationalities, ${ }^{26}$ though it has denied with reason that they have exclusive jurisdiction, inasmuch as the parties concerned have the right under the Capitulations to bring suit in Otto-

${ }^{24}$ For a concise summary of the immunities of jurisdiction in cases between foreigners of the same nationality, see Mandelstam, pp. 265-266; also Du Rausas, pp. 257-261.

25 Mandelstam, pp. 225-250; Du Rausas, pp. 294-4I I.

${ }^{26}$ This statement should be qualified to the extent noted above (p. 53) as regards questions of rent, mortgage, etc., which relate to the ownership of realty by foreigners according to the provisions of Ottoman law. These questions are in a sense, moot points on which an understanding has not yet been reached by the Porte and the Powers. 
man courts. In actual practice, however, recourse is not had to such tribunals; and usage has thus impliedly prescribed the consular courts as the proper tribunals in such cases.

In harmony with the legal principle actor sequitur forum rei, it is customary for the plaintiff to bring suit in the consular court of the defendant. An exception to this rule is found in the provisions of the British Orders in Council whereby British Courts in Turkey may assume jurisdiction in cases where the defendant is a foreigner who submits himself with the express consent of his government to be tried according to the law which is habitually administered in said British courts. Ottoman subjects have the same privilege. ${ }^{27}$

As has already been observed, the Porte has never disputed the jurisdiction of consular courts in civil suits between foreigners of different nationalities. Likewise, previous to $188 \mathrm{I}$ the Porte did not deny the competence of these courts in criminal suits between foreigners of different nationalities. The right of jurisdiction in such matters, under the Capitulations, was apparently considered by the Porte to be of the same character as the right of jurisdiction in matters relating to foreigners of the same nationality. The same principle was involved, namely, that the Porte was not concerned in any controversies between for-

${ }^{27}$ Hall, For. Jurisdiction, etc., pp. 161-163. Although British coults in Turkey are competent to try Ottoman subjects with the consent of the Porte, such a case has never arisen. The Porte would never give its consent to a proceeding so derogatory to the sovereignty of Turkey. 
eigners, but was concerned merely in questions affecting Ottoman subjects.

With the adoption of judicial reforms, and the increasing resentment of the Porte over the encroachments of the exterritorial system, the Turkish Government began in I88 I to claim jurisdiction in all cases between foreigners of different nationalities where the interests of the state in respect to public order and morals might be deemed to be involved. The Porte based this claim legally on its interpretation of the Capitulations, notably Article 52 of the treaty of I 740 with France, which reserved to the consular authorities jurisdiction in "disputes" between foreigners of different nationalities. The Porte claimed that the word "dispute" (niza) referred simply to contentions of a civil character, and that criminal questions, namely, murder (katl), misdemeanors (teuh$m e t$ ), etc., involving public order and morals, were undoubtedly within the exclusive competence of Ottoman courts.

The Powers disputed the correctness of the Porte's interpretation of the Article in question; but rested their claim to exclusive jurisdiction on recognized usage, asserting that "the alienation of a sovereign right may be completely effected through tacit abandonment." The Porte, on the other hand, argued that "sovereign rights might not be parted with by nonusage": that "sovereign rights are imprescriptible." etc. ${ }^{28}$

28 Mandelstam, p. 250. See also pages 225-250 for a masterly presentation of the merits of this controversy. 
It does not appear that the claims of either the Porte or the Powers are either expressly supported or disproved by the Capitulations. The position of the Porte seems to be clearly sustained through its inherent rights as territorial sovereign to be concerned with all that pertains to public order and morals. But the acquiescence of the Ottoman authorities in the exclusive jurisdiction of the Powers in all questions between foreigners of different nationalities over so long a period of time would sem to have amounted virtually to an abandonment of its sovereign rights of jurisdiction in such cases.

\section{Courts and Procedure}

In suits involving foreigners of different nationalities the same courts are resorted to and the same procedure employed as in cases involving foreigners of the same nationality. A peculiarity of this system, however, is found in the fact that the defendant may not bring a cross-suit in his own consular court but must sue in the court of the plaintiff. In case the competent court of appeal annuls the decision of the court, the defendant who may have been falsely accused and wrongly condemned is thus quite likely to have his petition for a cross-suit rejected by the consular court of the original plaintiff. ${ }^{29}$

\section{3-4. Law Administered. Exccution of Law}

The law enforced and the penalties inflicted in suits involving foreigners of different nationalities are the

${ }^{29}$ Du Rausas, p. 407. 
same as in suits involving foreigners of the same nationality except in the following instances indicated by Du Rausas: ${ }^{30}$

Usage, whose legal value and liberalism it is difficult to challenge, has established the following rules. The law to be applied, in principle, is that of the state in whose name the tribunal resorted to dispenses justice, that is to say, specifically, the national law of the defenciant, and in matters relating to inheritance, the national law of the deceased. This law, however, ceases to be applicable in three instances: (I) When it is a question of determining the status and legal capacity of the foreigner as plaintiff: the law to be applied then is the national law of that foreigner; (2) when it is a question of determining the validity of a juridical act, or when it is a question of interpreting an agreement and determining the effects of said act or agreement: the law to be applied is then the territorial law, whether the written law or local customs, in conformity with the rule locus regit actum and with the rule of (legislative) freedom of will (l'autonomie de volonté); (3) when, even outside of cases of the application of the rule locus rcoit actum and the rule of (legislative) freedom of will, the law of the tribunal concerned is in opposition to the local customs; for reasons which we have previously indicated, the local customs have force of law in the Ottoman Empire and should be applied even when they are in derogation of the law of the state in whose name the consular tribunal concerned, dispenses justice.

In addition to these judicial functions. consular officials in Turkey are usually empowered to perform acts of a juridical nature where foreigners of different nationalities are concerned, as for example notarial acts, and the celebration of the marriage ceremony.

The powers of the various consuls differ considera-

${ }^{30}$ Ibid., p. 407. 
bly in these respects. For example, Italian law authorizes Italian Consuls to solemnize marriages where both parties are Italian subjects or the husband alone is of Italian nationality. ${ }^{31}$ British Consular officials are empowered to solemnize marriages between British subjects, or when one of the persons is a British subject. $^{32}$ American Consular officials, however, have no authority to perform the marriage ceremony, though strange to say they may exercise jurisdiction in questions of divorce. ${ }^{33}$

To summarize existing usage under the Capitulations concerning foreigners of different nationalities, the consular tribunal of the defendant has jurisdiction as a rule in all civil suits. In criminal suits, the same tribunal likewise exercises jurisdiction, though the Porte has unsuccessfully maintained that Ottoman courts should have jurisdiction in such cases whenever public order or morals are involved. The courts and procedure in such cases, with slight variations, are the same as in cases between foreigners of the same nationality. The law enforced and the penalties inflicted are likewise the same, though the lex loci is frequently applicable in preference to the national law of the defendant. Consular officials have also certain extra-judicial functions such as the drawing up of legal instruments and the solemnization of marriages.

$31 \mathrm{Du}$ Rausas, p. 409.

32 Hall, For. Jurisdiction, etc., p. 87.

${ }^{33}$ United States Consular Regulations, 1897 , sections 4I7-422. 

THE JURIDICAL RIGHTS OF FOREIGNERS (Continued) 



\section{CHAPTER IV}

The Juridical Rights of Foreigners (Contimued)

C. IMMUNITIES OF JURISDICTION IN MATTERS AFFECTING BOTH FOREIGNERS AND OTTOMAN SUBJECTS ${ }^{1}$

I. Ottoman tribunals have jurisdiction in cases involving foreigners and Ottoman subjects except in mattcrs relating to the personal status of the former. ${ }^{2}$

The early Capitulations, particularly the French Capitulations of 1740 (Articles 26 and 65), left hardly any doubt as to the intention of the Porte to reserve to itself jurisdiction in all matters between natives and foreigners, or in the case of offenses against the state.

1 Mandelstam, pp. 49-208, 25I-255; Du Rausas, pp. 412-443; Young, Corps de Droit, etc., pp. 25I-278.

2 The exceptions noted include inheritance and bankruptcy which by some curious analogy are grouped together and considered within the province of the consular courts because involving questions of personal status. The power to settle the estates of deceased foreigners is assimilated to the power to settle the affairs of bankrupt foreigners. The execution of the decisions of consular tribunals in this respect is left to the Ottoman tribunals. As has already been pointed out (page 12) foreigners hold real estate subject to Ottoman law and jurisdiction. Wherever the personal status of the foreigner is involved, lowever, such questions may be deferred to the competent consular court. Here exists a conflict of jurisdiction of serious import but not of actual moment for the purpose of the present discussion. 
As already pointed out, however, the settlement of an ever increasing number of judicial questions through diplomatic, extra-judicial negotiations with the "Imperial Divan" proved to be a cumbrous, and entirely unsatisfactory procedure. The absence of reliable Turkish courts, as well as the lack of a code of laws applicable to foreigners, led the different consular tribunals during the first half of the nineteenth century to assume jurisdiction over cases involving their own nationals when defendants in suits brought by Ottoman subjects. But with the formation of proper courts and the promulgation of adequate commercial and penal codes under the judicial reforms of $\mathrm{I} 840$, I 847 , I 850 , I 860, i 867 , and I 879 , the Porte gradually resumed its jurisdiction in such cases, having secured the formal consent or the tacit acquiescence of the other nations excepting the United States, Belgium, and Portugal.

The treaties signed by Turkey with the United States, Belgium, and Portugal in $1830, \mathrm{I} 838$, and $\mathrm{r} 843$, respectively, all contained a like provision whose general purport, in contrast with the early Capitulations, was apparently to grant to the consular tribunals of these three countries absolute criminal jurisdiction over their own nationals without any reservations whatever as to arrest, trial, and punishment.

Article IV of the American treaty of 1830 , according to the English version officially maintained by the United States against the French version upheld by the Porte, reads in part as follows : ${ }^{3}$

${ }^{3}$ Moore's Digest, II, p. 7or. For a résumé of the official cor- 
. . Citizens of the United States of America, quietly pursuing their commerce, and not being charged or convicted of any crime or offense, shall not be molested; and even when they may have committed some offense they shall not be arrested and put in prison, by the local authorities, but they shall be tried by their Minister or Consul, and punished according to their offense, following, in this respect, the usage observed towards other Franks.

The French version of Article IV, according to the Turkish Government, is as follows:

Les citoyens Americains vaquant paisiblement aux affaires de leur commerce ne seront point molestés sans motif tant qu'ils n'auront pas commis quelque delit ou quelque faute; même en cas de culpabilité, ils ne seront pas imprisonnés par les juges et les agents de la sûreté, mais ils seront punis par les soins de leur ministre et consul á l'instar de ce qui se pratique á l'égard des autres Francs.

The official translation of this Article as given in Secretary Blaine's note 4 of December 22, I890, to Minister Hirsch reads :

American citizens peaceably attending to matters of commerce shall not be molested without cause or fault. Even in case of culpability they shall not be imprisoned by the judges and police agents, but they shall be punished through the agency of their ministers and consuls, according to the practice observed in regard to other Franks.

The serious divergence between these English and French versions of the Turkish text, which alone

respondence between Turkey and the United States on the subject of the arrest, trial, and punishment of Americans, see Moore, II, pp. 668-772.

4 Ibid., p. 701. 
should be held as authoritative, has rendered an adjustment of the controversy extremely difficult. Mr. Frelinghuysen, Secretary of State, fairly expressed the reductio ad absurdum of the Turkish contention as follows : ${ }^{5}$

So far as the Turkish position may be inferred from what has been said heretofore, it implies contention for four alternate stages of procedure, viz:

(a) The Turks to arrest (which is expressly forbidden by the Capitulations).

(b) The minister to imprison.

(c) The Turks to try the accused in the presence of their minister or consul (but without the latter exercising any of the "instrumentality" which the treaty of I 830 admittedly reserved to them); and

(d) The minister or consul to "punish" in accordance with the offense (although all instrumentality in fixing a punishment is denied to the minister or consul).

It would serve no particular purpose to go into the details of this long diplomatic logomachy in which the advantage would seem to have remained on the side of the United States. ${ }^{5 \mathbf{a}}$ The Department of State,

${ }^{5}$ Ibid., p. 696.

${ }^{5}$ While the United States has had the better of the argument in this controversy, it suffered a severe defeat in the test case of Charles Vartanian and Hovhanes Afarian, naturalized American citizens of Ottoman origin who were arrested and tried by the Turkish authorities in 1905 on the charge of killing a rich Armenian merchant in Constantinople. The Sublime Porte refused the demand of the United States for a stay in the proceedings pending a diplomatic adjustment of the whole question of Article IV, as well as the peremptory demand that the accused be handed over to the American Consulate-General for trial and punishment. The men were tried and sentenced without the presence at the trial of the American dragoman, Vartanian being condemned to death and Afarian to 
however, has been willing to make the substantial concession of trial by Ottoman courts, as in the case of other foreigners, though reserving the right to punish. ${ }^{6}$

At the time the Porte entered into the treaties with the United States, Belgium, and Portugal, the recognized usage concerning foreigners accused of crime by Ottoman subjects was that jurisdiction in such cases belonged to the consular tribunals. These separate treaties amounted, therefore, to nothing less than a formal and solemn recognition of existing usage. ${ }^{7}$ As impartial and reliable an authority as André Mandelstan, formerly First Dragoman of the Russian Embassy in Constantinople, fully sustains this point of view. ${ }^{8}$

If our opinions (says Mandelstam) as to the Turkish text of Article IV of the treaty of 1830 , be accepted, the

fifteen ycars' imprisonment at hard labor. Owing to the vigorous representations of the American Embassy, the Porte did not permit the sentence against Vartanian to be carried out. The United States allowed the matter to rest in this form. As the issue was clearly drawn, the result was most unfortunate in that it revealed that the United States was not prepared to insist in actual practice on what it claimed in principle. See Foreign Relations of the United States, 1905, p. 885.

${ }^{6}$ Ibid., p. 703 .

${ }^{7}$ Mandelstam, pp. I46-I5I.

8 Ibid., p. 163. For an excellent analysis of this whole question, see same author, pp. 152-174. Mandelstam treats of the Turkish treaty of 1823 with Sardinia, and the treaty of 1839 witl: the Hanseatic towns, containing similar provisions to those of the treaties with the United States, Belgium and Portugal. As botli Italy and Germany have allowed any alleged rights under the two treaties mentioned to lapse, they have not any value for the purpose of this discussion except to confirm the usage in respect to Franks at the time the three other treaties were made. 
question relative to the nature of the final clause 'according to the practice observed in regard to other Franks,' solves itself. The Turkish text, as moreover the French text of this Article, should not be considered as constituting a general most-favored-nation clause. The final reference of that text is only an illustration, an example. It does not purport to make American rights depend on French rights; after having described and specified American rights, it simply shows that the other Franks cnjoyed these rights at that time. It is in no way a most-favored-nation clause which would render the privileges conferred by Article IV uncertain, varying with the usage of other Franks. Article IV established an original and immutable American right.

Mandelstam further states his belief that the other nations through long acquiescence in respect to Ottoman jurisdiction over foreigners accused of crime by Turkish subjects, have forfeited any right to claim under the most-favored-nation clause the same privileges claimed by the United States, Belgium, ${ }^{\mathrm{s}}$ and

${ }^{8 n}$ An interesting test case between Turkey and Belgium arose in 1905, the same year of the test case between the United States and Turkey (note $5^{a}$ ), in the arrest and condemnation of Charles Edouard Joris, a Belgian subject, by the Turkish authorities at Constantinople, on the charge of an attempt on the life of the Sultan. "Joris was assisted at the trial before the criminal court by a representative of the Belgian Legation, who refused to join in the judgment of the court. After judgment the Belgian Legation demanded that Joris be handed over to the Belgian Government for trial before the court of assize of Brabant, which has jurisdiction, under Belgian law, 'over crimes committed by Belgians in non-Christian countries.' The Turkish Government refused to comply with this demand, and has maintained its attitude, notwithstanding the repetition of the Belgian demand." (American Journal of International Law, vol. I, p. 485 , 1907.) The case was finally disposed of by the action of the Porte in releasing Joris and permitting him to 
Portugal. But he believes that in case Ottoman justice should prove hopelessly inadequate and unsuited for foreigners, these privileges might afford by way of precedent considerable moral support to other nations desiring to withdraw their nationals from the jurisdiction of Turkish courts. ${ }^{9}$

Whatever may be the special privileges obtained by the United States, Belgium, and Portugal, through their treaties with Turkey, it seems reasonably clear that general usage and simple equity recognizes the right of the Porte in the exercise of territorial sovereignty to jurisdiction (with certain restrictions such as the assistance of foreign assessors and consular dragomans) in all cases, civil and criminal, involving foreigners and Ottoman subjects. The United States has been prepared to concede as much $;^{10}$ and the question at issue should be susceptible of amicable and satisfactory adjustment.

\section{Courts and Procedure ${ }^{11}$}

The Ottoman tribunals competent to assume jurisdiction in cases involving both foreigners and natives, or in cases of crime against the state, are the following:

leave the country. Professor Politis of the University of Paris in an article in the Revue de droit international privé (vol. II, p. 659), attacks the claims of Belgium to jurisdiction in this and sinilar cases, asserting that neither treaties or usage prevent jurisdiction by the Turkish courts.

${ }^{9}$ Mandelstam p. 173 .

10 Moore, II, p. 7o2.

11 For the laws, regulations and special provisions relating to Ottoman courts, and to the juridical privileges of foreigners, see Young, Corps de Droit, etc., vol. I, chapters VII to XV inclusive. 
(a) The "Tribunaux correctionnels" (to employ the designation borrowed from the French judicial system) are competent to try with the assistance of the consular dragoman any foreigner charged with a crime or misdemeanor against an Ottoman subject, or against the state.

(b) The tribunals designated in Turkish as Nizamich are competent to try: (I) all realty suits concerning a foreigner without the presence of a dragoman at the trial; (2) all questions of rent, if the owner is a foreigner, without the presence of the dragoman; (3) all civil suits between a foreigner and a native not involving a sum exceeding a thousand piasters $(\$ 44.0)$, the dragoman being present.

(c) The Mixed Tribunals, otherwise known as Commercial Tribunals, composed of three Ottoman judges and two foreign assessors assisting at the trial together with the consular dragoman, have jurisdiction in respect to all commercial litigations between an Ottoman subject and a foreigner, or any civil suit where the sum involved exceeds one thousand piasters. Appeal from the decisions of the Mixed Tribunals outside of Constantinople may be taken to the Mixed Tribunal in the capital.

The three classes of courts above indicated do not exist uniformly throughout Turkey. In certain localities the Mixed Commercial Tribunals or their equivalents have been suppressed. In such cases, commercial disputes are brought before the competent civil tribunals (Nizamich) ${ }^{12}$ with final appeal to the Mixed

${ }^{12}$ The Nizamich tribunals when trying commercial questions 
Tribunals in Constantinople when the amount involved exceeds a thousand piasters.

As previously pointed out, ${ }^{12^{a}}$ foreigners residing in places more than nine hours distant from their consular officials, are not entitled to precisely the same privileges as foreigners within the nine-hour zone. They are deprived of the assistance of the consular dragoman though they retain the right of appeal where the amount involved exceeds one thousand piasters.

As to the presence of foreign assessors ${ }^{13}$ in the Mixed Tribunals, these functionaries are designated by their respective Embassies and Legations for varying periods of service, and cannot be considered as judicial officials in the strict sense. Their functions are largely extra-judicial in character. When the decision of the three Ottoman judges may be contrary to the opinion of the two foreign assessors, the latter as a rule merely register their dissent in signing the procès-verbal. If they refuse, however, for exceptional and powerful motives to acquiesce in the decision, it then becomes necessary to leave the matter to diplomatic adjustment through the medium of the Ministry of Justice and the Sublime Porte,- - a procedure which cannot fail to be most unsatisfactory whatever the result.

of this character are authorized to allow foreign assessors to assist in accordance with the practice of the Mixed Tribunals in this respect. (Young, I, p. 243.) The Porte does not recognize the right of foreigners to insist that foreign assessors be summoned in such suits, but has often been compelled to concede in practice what it denies in principle.

12a See page 45 supra.

13 Mandelstam, pp. 77-82. 
The Porte for a time objected to the presence of a foreign assessor of a nationality different from that of the foreigner party to the suit, but afterwards withdrew its objection when it became evident that in some instances a competent assessor of the same nationality would not be available. ${ }^{14}$

The original Capitulations guaranteed the right of a foreigner to the assistance of his ambassador, consul, or of their representative, the dragoman, in all trials before the Ottoman courts. ${ }^{15}$ What was meant by "assistance," however was never well defined, and the Porte, while making a virtue of a necessity, has long denied the right of the dragoman to exercise certain powers which that official has accumulated in the course of time. Du Rausas remarks in this connection that :

.. . the extent of the powers of the dragoman varies every day; it varies with the consulates, with the dragomans themselves; it lepends upon the relations which the ambassador of this or that Power maintains with the Porte, of the attitude more or less favorable to foreigners which the president of this or that tribunal may hold, sometimes also of the ability demonstrated, or of the personal sympathy which this or that consul or dragoman may inspire. ${ }^{10}$

Without attempting to discuss the merits of the controversy between the Powers and the Porte con= cerning the functions of the dragoman, we may take note of the ordinary usage followed in this respect, as set forth by Du Rausas.

${ }^{14}$ Young, op cit., I, p. 243.

15 Mandelstam, pp. 82-94. Also supra p. 36.

${ }^{16}$ Du Rausas, p. 438. 
The mission of the dragoman is not simply that of an interpreter; it is a mission of control and surveillance. This being admitted, it is very evident that it is necessary to give to the dragoman the practical means of fulfilling efficaciously his mission of control and surveillance. These means are, and cannot be otherwise than the power recognized in the dragoman to stop the proceedings, as the case may be, or prevent the execution of the decision. Hence the necessity of the vise and the signature: they must be affixed to all important papers in the proceedings, that is to say, in a civil suit, to the original complaint, to the records of the investigation and examination (into the facts), to the final sentence; and in criminal suits, to the summons to appear before the examining magistrate, to the records of the examination (of the person accused), or of the hearing of witnesses, to the rulings of the magistrate, and finally, to the sentence of condemnation. ... The presence of the dragoman, indicated by his visé and signature, is a guarantee of the validity of the proceedings and of the sentence. If, then, the visé and the signature of the dragoman do not appear on a document where they normally should appear in the proceedings, this document is inapplicable to the foreigner, with the result that the trial may not begin, or is terminated. Especially, if the visé and the signature of the dragoman do not appear on the order for arrest issued against a foreigner, or on the sentence of conviction pronounced against a foreigner, that order and that sentence may not be carried out. ${ }^{17}$

From the foregoing excellent summary it may readily be appreciated how many occasions for contention and friction may arise between the dragoman and the Ottoman authorities; how the normal course of justice may be unreasonably interrupted at times; and finally, how thoroughly objectionable to the Turks must be this autocratic control over their courts, es-

17 Ibid., pp. 439-410. 
pecially when exercised by subordinate foreign officials not always well versed in local laws and customs. To such an extent is this control carried that the Turkisk Government is unable to carry out the decrees of the Cour de Cassation, the supreme judicial tribunal of the Empire, owing to the fact that the Powers refuse to acknowledge its juriscliction over foreigners without the assistance of the dragoman at the trial.

For the sake of justice, as well as out of respect to the rights of territorial sovereignty, whenever it may be shown that the rights of foreigners to a fair trial are properly protected, it would seem of the utmost importance that the Porte should secure the consent of the Powers to an extensive curtailment of the supervisory control of the dragoman over Ottoman courts.

One other fact to be noted in respect to the procedure in Ottoman courts is that suits brought against Turkish subjects by foreigners are commenced through the medium of the proper diplomatic or consular otficials. This is done by the dragoman who presents to the Mixed Tribunal the charges duly translated into Turkish. This tribunal must likewise employ the same agency in order to notify foreigners of summonses and sentences of the courts. In such cases the legal delays for appeal, etc., date from the day when the consulate receives the notification in question. ${ }^{18}$ Following the rule laid down by the early Capitulations, all evidence of transactions on which

18 Young, I, p. 246. 
suits are based must be presented to the Mixed Tribunal in writing. Charges based on oral testimony may not be entertained. ${ }^{19}$

\section{The Law Administered ${ }^{20}$}

The law lying at the base of all laws in Turkey is the Sheri, the Moslem sacred law, which in theory cannot countenance any legislation contrary in any respect to its precepts. However, when the system of mixed commercial tribunals was adopted in 1848 with the consent of the Powers, a commercial code was adopted (two years later); an appendix to the code was published in I860; a code of commercial procedure, in I 862 ; and finally, a maritime commercial code, in 1864 ,- -all with the approval of the Powers. These codes were drawn for the most part from the French commercial codes though in a very defective manner. The Mixed Tribunals when endeavoring to supply the deficiencies of the Ottoman commercial code had recourse to the principles of the French code. But with the adoption of the Ottoman civil code, the Medjolle, in I868,- - a code compiled mainly from the Sheri,- the Mixed Tribunals began to have recourse to this body of law. The Medjelle, based as it was on the sacred law, is not in harmony in all respects with the principles of the codes drawn from French sources. It does not recognize for example the element of usury in commercial enterprises.

19 Ibid.

20 As to the law applied in mixed suits in Ottoman tribunals, see Mandelstam, pp. I-60, 96-I I I, 206-208. 
The Powers have insisted that inasmuch as the Ottoman commercial cole is based on the theory and principles of the French code, any defects in the former should be supplied from the original source. The Powers, moreover, deny to the Porte the right to amend the commercial code without their consent. The result, as may readily be conceived, is that there exists a most serious divergence of views as to the law to be applied in the Mixed Courts. It would seenr obvious, as insisted by Mandelstam, that an understanding on this subject between the Porte and the Powers is indispensable. ${ }^{21}$

The law which is applied in the civil and criminal courts in cases involving foreigners, is that contained in the civil and criminal codes, and in the regulations relative to the enforcement of the decrees of the courts, promulgated by the Porte in 1879 . Though based largely on French laws, these codes and regulations have never been approved by all the Powers because of the fact that they contain features considered inapplicable to foreigners, such as for example imprisomment for debt. Wherever these codes are defective, the tendency of the Turkish courts is to have recourse to the Sheri.

It should always be borne in mind that the Ottoman tribunals are subjected, in their application of law in the case of foreigners to the restraining influence of the foreign assessors and the consular dragoman.

21 Mandelstam, p. II I. 


\section{Execution of Law $^{22}$}

The actual practice observed in regard to the carrying out of the decisions of Ottoman courts in commercial and civil suits cannot be more clearly summarized than in the words of Mandelstam.

In respect to the execution of the decisions of Ottoman courts rendered against foreigners, there are ... five different systems. One group of nations, Russia and Austria-Hungary, proceed to the execution of these decisions through the medium of their own consulates and according to their own laws in respect to the execution of decisions. A second group of states, France, Belgium, and the United States, permit the carrying out of Turkish decisions according to Ottoman law, except in those cases where it is in flagrant opposition to the law of the foreigner, as in the matter of physical constraint. A third group of states, Germany, Italy, and Roumania, atthorize the execution of decisions by the agency of their consulates, applying the Ottoman law even when it is contrary to their national laws. A fourth system, adopted by England, leaves the execution of decisions in the hands of the Ottoman atthorities. The fifth system, finally, which is that assigned to Greece by the arbitral award of $1901,{ }^{2 \mathrm{a}}$ recognizes the right of execution of decisions by the consular authorities, save to cause the right to revert to the local authorities after a certain delay.... The execution of the decisions of Ottoman courts against Ottoman subjects and in favor of foreign subjects belongs indisputably to the Ottoman authorities. ${ }^{23}$

In regard to the arrest and detention of foreigners accused of crimes before the Ottoman courts, it may be said that most of the Powers, while differing as to

22 Ibid., pp. 138-144, 185-192, 208-2 II.

$22^{a}$ See page 4 I supra.

23 Ibid., p. I 43. 
the handing over of such persons to the consular authorities, claim in principle the right of detention during trial, though in practice this right is often waived by certain of these states.

In criminal cases, the Powers with the sole exception of Austria-Hungary have never expressly renounced the claim to the right of foreigners convicted and sentenced in Ottoman courts to serve their sentences in consular prisons. Germany, Holland, Russia, and naturally the United States, have always maintained this right. England, Spain, France, Italy, Greece, Persia, and Sweden, allow their nationals, with occasional exceptions as in the case of imprisonment for debt, to be imprisoned in Turkish jails. ${ }^{24}$

\section{INVIOLABILITY OF DOMICILE 25}

Article 70 of the French Capitulations of 1740 proclaimed, and the Protocol of 1867 confirmed the inviolability of the domicile of foreigners. In the process of time, however, the Ottoman Government has sought naturally to place limitations on this immunity especially as regarding hotels and printing establishments. The Powers have as strenuously maintained their extreme pretensions in this respect.

Without attempting to go into a discussion of the

24 Young, I, pp. 253-256.

${ }^{25}$ Mandelstam, pp. I76-I85; Du Rausas, pp. I29-133. The principle on which the inviolability of the domicile of foreigners is based, as expressed by Du Rausas, is "The Ottoman authorities have no jurisdiction over the domicile because they have no jurisdiction over the person of a foreigner." See also page 45 supra. 
merits of various controversies over this matter, we may note briefly the practice generally observed in reference to the visit and search of the houses, shops, etc., of foreigners.

(I) "The domicile of a foreigner may not be visited by the local authorities without consular assistance, except in the instances noted in the Protocol of I867."26

(2) The Powers have insisted that "consular assistance is equally necessary in those instances where the local authorities proceed to investigate and search printing establishments, bookstores, liquor shops, places of public amusement, and all other similar establishments, as also hotels, apartments, or hostelries, kept by foreigners."'27

(3) "The inspection of foreign vessels is absolutely forbidden to local authorities. Foreign subjects who have committed an offense or crime on shore are not handed over to the authorities; but Ottoman subjects may be surrendered upon the presentation of a proper order of arrest." 28

(4) The local authorities, in some instances, ${ }^{29}$ have

${ }^{26}$ See also supra pages 45 . The quotations here cited are from Mandelstam (p. 184).

${ }^{27}$ While the Powers have resisted in principle the claims of the Turkish police to exercise a close surveillance over public resorts, they have occasionally acquiesced in the entrance and search of foreign hotels, etc., by the competent local authorities.

28 See also footnote 26 to chapter II.

${ }^{29}$ It would be unreasonable to deny the right of the Turkish authorities to enter the house of a foreigner in case of fire, murder, or any serious disturbance amounting to a breach of the peace. 
the right to enter the domicile of a foreigner accused of a crime or offense, in order to make the necessary investigation; but this does not confer the right to arrest or imprison. The Porte has declined to admit that the Turkish authorities have no such right, and consequently difficulties in this connection are constantly arising.

\section{E. SPECIAL IM MUNITIES}

\section{Consular Immunities ${ }^{30}$}

In view of the extraordinary powers of consular officials in Turkey, usage and the Capitulations have accorded to them and their families, as well as to their dependents, the same privileges and immunities usually granted to diplomats and their suites. That inviolability of domicile which is the right of all foreigners is doubly the right of all consular representatives. If, however, a consul owns land or engages in business, he may not claim any greater privileges than enjoyed by other foreigners.

In common with all foreigners, consuls are exempt from personal taxes.

The regulations ${ }^{31}$ concerning consular rights and privileges promulgated with the consent of the Powers July 27, 1869, exempt the personal as well as the official effects of consular officials from customs duties. These regulations also conceded to consular officials engaged in business certain customs exemptions varying in extent with the rank of the official. ${ }^{32}$

${ }^{30}$ Du Rausas, pp. 467-480; Van Dyck's Report, Appendix VII. 31 Van Dyck's Report, Appendix VIII.

32 Du Rausas, p. 479. 


\section{Protégés ${ }^{33}$}

An anomalous condition of affairs has arisen since the earliest establishment of foreign communities in Turkey in regard to the protégés, native as well as foreign, withdrawn from Ottoman jurisdiction and placed under the protection of the various Powers. These special immunities have accrued to the dependents of foreigners mainly in order to guarantee effectively the free enjoyment by foreigners of their immunities in respect to persons, residence and business.

Various Powers for political purposes have sought to extend their protection, either in a general way over certain sects, as France for example over the Syrian Catholics, or in a more specific manner, over different monastic and other religious communities.

So many abuses arose in connection with the protection accorded to Ottoman subjects that the Porte in I 863 with the consent of the Powers promulgated full regulations defining clearly the status of all protégés. ${ }^{34}$

The various classes of protégés together with their respective privileges are as follows:

(a) Consular Protégés. These include all native consular officials such as vice-consuls, consular agents, dragomans, clerks, and guards (Cavass). They are uncler the protection of the country they serve, and while performing their official functions are entitled for general purposes to the same privileges as nationals of that country.

33 Ibid., II, pp. 1-79.

34 Van Dyck's Report, Appendix VI. 
(b) Forcign Protégés. Many foreigners, the Swiss, for example, are without diplomatic or consular representation in Turkey, and are entitled to elect the protection of certain Powers which practically all of the privileges and rights of nationals of the country empowered to grant protection.

(c) Religious Communities. ${ }^{35}$ Certain monasteries and other religious communities, some of which were formerly uncler the protection of the Papal States, and others which France, Russia, Austria-Hungary, and other Powers have asserted the right to protect, are regarded as of the nationality of the protecting nation.

The head of these religious establishments and communities together with their superior officials including the dragomans are entitled to immunities closely resembling those granted to consular establishments.

A curious feature of this system is that if an individual in such a community commits a mislemeanor in the exercise of his religious cluties, he receives the consular protection of the nation claiming jurisdiction over the community. If, however, he should commit an offense as an individual while not engaged in his religious functions, he would properly be entitled to the protection of the consulate of his own nationality whatever that might be.

It is also of interest to note that these religious communities through the generosity of the Turkish Government have been granted certain exemptions

${ }^{35} \mathrm{Du}$ Rausas, II, pp. 80-I75. 
from customs duties. These privileges in turn have been claimed by all other religious communities including the American Protestant Missionary establishments throughout Turkey. ${ }^{36}$

(d). Permanent and Other Protégés. Prior to the promulgation of the regulations of 1863 restricting the rights of protégés, many Ottoman subjects had acquired the status of protégés, and were allowed by the Porte to maintain this exceptional status as an hereditary right. ${ }^{37}$

While employees of foreign commercial houses and other establishments have no definite right to be treated as foreign protégés, they enjoy as a matter of fact a very large measure of immunity from Turkish jurisdiction. The euphemistic "unofficial good offices" of the foreign employer's government are most effectively brought into play in their behalf at times; and the Turkish authorities are ever reluctant to invite diplomatic intermeddling by reason of any alleged interference, either direct or indirect, with the personal or business interests of any foreigner. It is therefore more prudent, even under severe provocation, to leave the native employees of foreign establishments severely alone.

\section{Inviolability of Correspondence ${ }^{38}$}

The freedom of foreigners to engage in trade and maintain establishments subject to the jurisdiction of

${ }^{36}$ Van Dyck's Report, Appendix XIV.

${ }^{37}$ Du Rausas, II, pp. 64-74.

${ }^{38}$ Ibid., I, note I on page 417 . See also Journal de Droit International Privé, I901, p. 617. 
their own govermments carried with it the freedom of communication and correspondence. The Turks gave themselves no concern until recently as to how foreigners carried on their correspondence. The result has been the development of a complete postal service for the benefit of foreigners, and of those natives as well who choose to use it, entire withdrawn from the supervision and control of the Turkish Government. The six great Powers all maintain their own postoffices in various parts of Turkey, and carry on a large proportion of the postal operations which naturally should lie within the competency and province of the Ottoman postal service.

A privilege of this character which does not rest on any specific grant of the Capitulations, and which is most offensive to the amour propre of the Turks, must inevitably be relinquished as soon as it can be demonstrated that the Turkish post-offices are efficient and reliable.

\section{SUMMARY}

We have traced in rough outline the origin and evolution of the régime of the Capitulations. We have noted the historical bases of the juridical rights of foreigners in Turkey, and have endeavored to determine the exact nature of these rights. We have observed certain features of this régime which would seem to require considerable modification. We are conscious that so abnormal a state of affairs cannot endure indefinitely. ${ }^{39}$ As to just how it will be possible

${ }^{39}$ The official attitude of the Turkish Government is reflected 
to reconcile the point of view of the Powers who are naturally bound to protect the interest of their own nationals, with the point of view of the Imperial Ottoman Government whose jurisdiction as territorial sovereign has suffered such serious and humiliating limitations, is difficult to conjecture. And yet it would seem necessary before leaving the subject to seek, if possible, some reasonable solution of the problem,-some rational, working hypothesis on which to base future adjustments between Turkey and the Powers. This task will be the object of the following chapter.

in the views expressed by Count Ostorog, at that time legal advisor of the Ministry of Justice, in an interview published in the Stamboul of Constantinople under date of September I4, I9Io. (Quoted also by Mandelstam, page vii.) "Le gouvernment ottoman ... ne pense pas exiger la suppression absolue et immediate des Capitulations, estimant que ce serait prématuré. Pour le prouver il suffit de rappeler les declarations faites par le Ministère de la Justice, Nedjmeddine Bey, á un rédacteur du Tanine au cours d'une interview sur la question. . . . D'apres les aveux même des legistes les plus impartiaux et les plus eminents, il est patent que l'application étendue des Capitulations a donné lieu á des hesitations, á d'intiles differends et quelquefois aussi á des faits absoluement contraires au droit et á l'équité. ... Il faut reviser les dispositions des Capitulations; supprimer les causes de conflit ainsi que tout ce qui est de nature á blesser l'amour-propere national et á donner lieu á un refroidissement dans les relations entre les ottomans et les étrangers; enfin trouver un modus vivendi provisoire basé sue l'amitié, la sincerité, le droit et la justice. Voila ce que demande le gouvernment imperial. Quel est le gouvernement, l'homme d'Etat qui puisse taxer cette prétention d'exageration et d'inopportunité." 

IMMUNITIES, OF JURISDICTION AND INTERNATIONAL LAW 



\section{CHAPTER V}

ImMUNities OF JURISDiction AND International LAW

The rights of aliens would logically appear to be the most important concern of international law. It would seem that there could be no law of nations which did not arise from the relations of individuals in international intercourse.

Nations cannot act as impersonal entities with absolute consistency. In their relations with each other they deal as men with men. If these relations are disturbed, it is through the action of men, and very frequently the catse of international differences is to be found in the grievances of individuals. This truth is illustrated in many different ways. For example, the rights of citizens of a neutral state who may be engaged in the sale, shipment, and transportation of goods of the nature of contraband of war are to be determined by the rules of international law. Article 4 of the Hague Convention for the Establishment of an International Prize Court permits an individual to appear before the Court in certain instances. ${ }^{1}$

The extradition of foreigners is a matter which concerns the individual quite as vitally as the state, and is properly regulated by recognized rules of international law.

${ }^{1}$ A. Pearce Higgins, The Hague Peace Conferences, p. 409. 
The exceptional status of merchant vessels and their crews in foreign ports is also expressly set forth in all treatises on the law of nations.

Many of the most serious diplomatic incidents, leading to warlike aggression in some instances, have arisen over the alleged violation of the rights of aliens. Witness the acts of reprisal on Greece by England in I 850 to secure reparation in the case of Don Pacifico, ${ }^{2}$ as well as the blockade of Venezuela in 1902 by England, Germany, and Italy, to obtain payment of claims held by their nationals. ${ }^{3}$

It not infrequently happens that a nation reserves to itself the right to protest vigorously, and even intervene by force, whenever it is convinced that its nationals are not protected in their rights by the courts or by the responsible officials of another country. Italy in I891 very properly made the failure of the authorities of New Orleans to protect Italian subjects from mob violence the basis for drastic diplomatic representations; and the United States as properly responded by the payment of an indemnity. ${ }^{4}$

All such matters are recognized as being within the province of diplomatic negotiations, and deserving the solicitous consideration of nations. ${ }^{5}$ And yet, when the international law publicists approach this

${ }^{2}$ Scott's Cases on International Law, p. $46 \mathbf{1}$.

${ }^{3}$ Moore's Digest, VI, p. 586.

4 Scott, op cit., pp. 328-329.

5 Despagnet in Droit International Priz'é (page I7) goes so far as to affirm that, in matters of conflict respecting penal laws, recourse should be had rather to international public law than to international private law. 
immense field of the rights of individuals within foreign jurisdictions, they seem to attempt to leave it one side by affirming that international law has only to do with the relations of states. ${ }^{6}$ The rights of individuals, they say, are to be treated properly as a separate branch of law denoted paradoxically as Private International Law, International Private Law, or preferably, as Story tried to solve the difficulty, Conflict of Law's.

It has been said that there is a natural tendency in the human mind to define a thing in order to avoid the necessity of understanding it. It would be unjust perhaps to apply this stricture to those publicists who hold that the question of the general powers and jurisdiction of nations over the foreigners within their borders is not properly the concern of international law, but that it "is merely a subdivision of national law", and "derives its force from the sovereignty of the states administering it." ${ }_{7}$ It still remains true, however, that if one so defines this subject he is spared the necessity of giving it the earnest consideration it would seem to deserve.

The English and American writers on this subject, ${ }^{8}$

6 Hall, International Laa,, p. 51; Oppenheim, International Late, I, p. I8 (ed. I905) ; Bonfils, Droit International, p. 2.

7 Hall, pp. 51-52.

${ }^{8}$ Story, Conflict of Laa's, Chapter II. (3d. ed.) "The first and most general maxim or proposition is that ... every nation possesses an exclusive sovereignty and jurisdiction within its own territory" (p. 28). See also Dicey, Conflict of Lazes, pp. I2-15, 38 (ed. I\&96); Westlake, International Priz'ate Law, pp. 4, 20 (ed. I880); Phillimore, International Law, vol. IV. 
notably Dicey and Story (Phillimore shows a distinct tendency in a more liberal direction), weighted down by the feudal traditions of the Common Law as a law strictly territorial in character and scope, have jealously endeavored to maintain that the power of the territorial sovereign over all persons within his jurisdiction is absolute. They claim that his courts are bound to recognize no other laws as having extraterritorial force in his territory except such as they may be pleased to recognize on the grounds of "international comity and mutual utility.'

The continental writers on international law, on the other hand, protest that no right can rest on comitas gcntium: that a right demands recognition because of its own intrinsic merits. ${ }^{10}$ These writers, who are under the sway of Roman Law, have almost unanimously maintained that the territorial sovereign by no means has absolute power and jurisdiction over the foreigner within his territory. They maintain that foreigners should have the benefit of their own laws

chapter on comity (ed. 18;9); Holland, Jurisprudence, op. cit., chap. XVIII.

9 "The true foundation on which the administration of international law must rest, is, that the rules which are to govern are those which arise from mutual interest and utility." Story, p. 45 .

${ }^{10} \mathrm{Ce}$ n 'est donc pas en vertu d'une concession gracieuse (comitas gentium) mais bien en obeissant à une règle de droit, c'est-á-dire de raison et justice, tirée de la nature même des relations internationales, que chaque pays accepte, dans certains cas, sur son territoire, l'application de la loi étrangère. Despagnet, p. 26 . 
whenever such laws are in no way opposed to the public order and law of the sovereign state.

In other words, the continental authorities in international law in opposition to the Anglo-American authorities most emphatically deny that the rights of aliens are to be determined solely by the varying legislation of each sovereign nation. They insist with convincing logic that these rights are essentially international rights to be determined only through the joint agreement of nations. Nor is this mere abstract reasoning or a verbal contention. The chief nations of Europe have already embodied in formal international compacts those principles of law and rules of procedure which should be observed in the treatment of aliens respecting marriage, divorce, guardianship, inheritance, and civil matters. ${ }^{11}$

The problem concerning the abstract rights of foreigners is presented concretely and most uniquely in the case of Turkey. The solution of this problem should be in accordance with sound international principles rather than as a modus vivendi in frank derogation of any hitherto accepted principles of the law of nations. It should no longer be treated under the absurd and unsatisfactory fiction of exterritoriality as an exception to the general rules of international law. A sound working hypothesis should therefore be found to solve this problem in order to afford a basis for future adjustments between the Powers and Turkey.

${ }^{11}$ See Actes de ha Troisième Conference de la Haye sur le Droit International Privé, 1901. 
In view of the fact that the continental writers on international law are practically united in treating the rights of aliens as properly the first concern of the law governing the intercourse of nations, their views, in so far as they apply to the subject immediately at hand, cannot fail to be of especial interest.

Professor Politis of the University of Paris states: ${ }^{12}$

There is an opposition and contradiction, it seems, between the terms "international" and "private." If our law is international, it could not be private, because once a relation between states is established, recourse is had to a public law. If then, being international, it is public, it blends with the law of nations of which it appears as a special branch. ... Now, in every matter of private international law, one is in the presence of a conflict of two sovereignties. In a conflict of laws, the question is to know which is the competent law; and, as the law itself has authority only because it is the expression of the will of the legislator, this amounts to demanding who is that legislator, that is to say, the sovereign who has the right to see that his orders are obeyed so far as they have relation to the subject matter. This, then, is a conflict between sovereignties, cractly as in the law of nations. Hence they are the same principles which should govern its solution.

In a memorandum presented by the Roumanian delegate to the Third Conference of the Hague for the Codification of International Private Law, occur the following observations $:^{13}$

The principles of international private law to-day are enjoined on all states by virtue of a rule consecrated by the law of nations. According to this rule, states owing to each other a mutual respect of their sovereignty, are

12 Journal de Droit International, 1908, p. 409.

${ }_{13}$ Actes de la Conference de la Haye, etc., 1901, p. I60. 
obliged to reciprocally respect the rules of private law by means of which, each of them protects its nationals, its persons, and its interests. Respect for foreign law, then, is not founded on a grant, but truly on a rigorous application of the principles of international law.

The following excerpts from various international law publicists will serve to support these main points, and also emphasize other important aspects of this question.

\section{Pillet:}

From the moment states gave themselves over to international commerce and reciprocally authorized their subjects to devote themselves to it, they tacitly consented to the mutual penetration of their sovereignties. ${ }^{14}$

Each sovereign should tolerate on its territory the application of foreign laws to the extent that said application serves the common advantage of nations. ${ }^{15}$

The first question which international law should solve is that of the juridical status of foreigners. ${ }^{16}$

It is therefore certain that the state has not the same freedom of action towards the foreigner that it possesses towards a national. ${ }^{17}$

To deprive a foreigner arbitrarily of the benefit of his personal status, is to refuse to recognize the civil effects of his standing as a foreigner; it is to strike a blow at the right of legislation which the foreign state preserves over its subjects abroad. ${ }^{18}$

Rights duly acquired should be respected in inter14 Pillet, Principes de Droit International Privé, p. 73 (ed. I903).

15 Ibid., p. 53.

16 Ibid., p. 168.

17 Ibid., p. 196.

18 Ibid., p. 202. 
national society. This idea of respect among the nations comprised in the international community, implies together with the obligation to do nothing that may weaken or destroy a right duly acquired, the duty to guarantee on their territory every consequence (of these rights) compatible with the exigencies of public order. ${ }^{19}$

\section{Despagnet :}

It is therefore not by virtue of a gracious concession (comitas gentium) but indeed in obeying a rule of law, that is to say, of reason and justice, deduced from the nature of international relations, that each country accepts, in certain cases, the application of foreign law on its territory. ${ }^{20}$

\section{Fiore:}

... One may henceforth consider as a rule of law common to all the states of Europe, that laws relative to

${ }^{19}$ Ibid, 534. The following observations of the same trend by Pillet also deserve quotation. La souverainété a franchi les limites territoriales de l'Etat du jour ou une personne a été admise á entretenir des relations hors de sa patrie: la reconaissance de l'effet extraterritorial d'une souverainété étrangère (page 58). La loi internationale doit s'efforcer de porter au plus haut degré l'autorité des lois nationales dans le domaine des relations internationales (page 150). Dans les relations internationales la nationalité joue le rôle du premier element d'ordre sur lequel repose la possibilité d'une communauté juridique, et cela même dans les pays qui n'accordent á la loi nationale aucune competence dans la solution des conflits. $\mathrm{La}$ nationalité est l'element qui differencie le citoyen de l'étranger, c'est elle qui donne le plus souvent á une question de droit sa forme internationale (page 176 ).

${ }^{20}$ Despagnet, op. cit., p. 26. He qualifies this statement later on as follows: Un premier point hors de doute c'est que l'étranger ne pourra jamais invoquer les dispositions de sa loi nationale pour faire regler son état et capacité, quand ces dispositions seront contraires aux principes d'ordre public admis dans le pays ou il se trouve (page $47 \mathrm{I}$ ). 
status and juridical capacity follow the citizen everywhere. ${ }^{21}$

\section{Laurent :}

Burgundus said that "land attracted man to itself," or, as M. Mignet stated it, "man was in a way possessed by the land: while according to our modern ideas, land is the accessory of the individual." So it was in all things the law of the land which should preponderate under the feudal régime, and today it is the individual and his rights that control. ${ }^{22}$

The Anglo-American jurists start with the principle that each nation has an exclusive sovereignty on its own territory. ... This is the principle of the Middle Ages. ... Sovereignty is no longer, as it was in the Middle Ages, the power, and if necessary, the caprice of the proprietor who might use and abuse his possessions. Its mission is more elevated. ${ }^{23}$

If sovereignty is territorial, said Savigny, and if sovereign power is absolute, the foreigner will be at the mercy of a sovereign who may do all that he wills; that is to say, he is without law. This is what the common law, so dear to Anglo-Americans, teaches us. ${ }^{24}$

Comitas has nothing in common with law (droit); it is on the contrary the negation of law. As concerns

${ }^{21}$ Fiore, Droit Internationale Privé, p. 8I (2d. ed.). Fiore also remarks that: le souverain territorial ne peut avoir aucun intérêt á soustraire l'étranger á l'empire de sa loi naturelle et á lui imposer des lois faites pour ses propres citoyens. Son droit unique est d'empecher que l'étranger n'exerce ses droits sur le territoire qui lui est soumis en vertu de la loi de son pays lorsque l'exercice et la reconnaissance de ces droits est contraire aux principes d'ordre public et de droit public en vigeur sur le territoire. . . . le système qui donne la préférence á la loi nationale est en principe le plus conforme aux principes rationnels (page 83 ).

22 Laurent, Droit Civil International, p. $27 \mathrm{I}$ (ed. I880).

23 Ibid., p. 553.

24 Ibid., p. $56 \mathrm{I}$. 
territorial sovereignty, it is dominated by a law which is superior to it, the society of mankind which should be ruled by one and the same law. ${ }^{25}$

\section{Heffter :}

The state which would deny the authority of a civil law other than that it has established, would at the same time cleny the existence of other states and the equality of their rights with its own. ${ }^{28}$

\section{Mancini :}

The treatment of foreigners cannot be dependent on the comitas and the sovereign, arbitrary will of each state. Science can only consider this treatment as a strict obligation of international justice from which a nation may not escape without breaking the bond which unites the human species in one great community of law, founded on the community and the sociability of human nature. ${ }^{27}$

\section{Holtzendorff :}

What a blow to the authority of civil law, if the fact of having crossed the boundary of a territory should cause the rights of a citizen to depend on the arbitrary wil! of a foreign functionary! In order to assure these rights, especially in the time of easy communication in which we live, solid guarantees are needed which should safeguard them beyond even the area of the control of territorial laws. It is here that private laze finds its point of contact with the law of nations. ${ }^{28}$

The consensus of opinions above quoted would seem to lead to the following general conclusions:

I. The rights of foreigners may not be subject to the unrestrained judgment and action of any one

25 Ibid.

${ }^{26}$ Heffter, quoted by Despagnet, page 22.

$2 \pi$ Mancini, quoted by Laurent, p. 637.

28 Holtzendorff, quoted by Despagnet, p. 23. 
nation. Sovereignty does not confer on the territorial legislature full power over foreigners. ${ }^{29}$ Their rights may be determined only by the deliberate, united agreement of all nations, in accordance with the most liberal conceptions of the law of nations. International, not national jurisprudence must have sway.

II. Foreigners carry with them wherever they go such rights as accompany their nationality, in so far as the recognition of such rights is not repugnant to the law and order of the state within whose juriscliction they may temporarily reside.

III. These rights are in general terms such as relate to civil status and capacity, and include such matters as marriage, separation or divorce, legitimation, guardianship of minors, idiots et al., inheritance, settlement of estates, bankruptcy, etc., etc. (In penal matters, as has already been noted, ${ }^{29^{\mathrm{a}}}$ nations reserve the right to prctect their nationals against unduly harsh punishments such as imprisonment for debt, or against any evident failure of foreign courts to accord full justice.)

IV. It is most desirable that these rights should be definitely determined by international agreements. Where this is difficult, or impossible by reason of a serious divergence in systems of law and procedure. as for example in the case of Italy and the United States, or Russia and Japan, the general principles

29 For a forceful presentation of this point of view, see, Consultation pour les Socićtés d'assurance sur la Vice, by Edonard Clunet (Paris, 1912).

$29^{n}$ See page 102 supra. 
governing the rights of foreigners should formally be recognized and respected to the fullest possible extent. They should not be made to depend on international comity but on international law.

Applying now these general observations to the particular problem at hand, namely, the finding of a working hypothesis on which to base future adjustments of the Powers with the Porte in regard to the protection of foreigners, with due respect to the sovereign rights of Turkey as an independent, equal state in the family of nations, we are led to the following conclusions :

I. According to the basic principles of international law, Turkey should have exclusive jurisdiction over foreigners, as well as natives, in all matters affecting public law and order in the Empire. This is essentially a fundamental right of independent sovereignty.

Turkish criminal and civil law should therefore be made to accord fully both in form and substance with the law generally accepted in all civilized lands. The introduction of judicial reforms and adequate guarantees for the proper dispensation of justice should prove merely a question of time. Once accomplished, there do not appear to be any insuperable obstacles in the way of securing the consent of the Powers to the complete renunciation of criminal jurisdiction on the part of the consular courts. Public law and order cannot tolerate conflicting criminal jurisdictions within the same territory.

Furthermore, a necessary corollary to the recogni- 
tion of the independent jurisdiction and integrity of the Turkish courts would be the renunciation by the Powers of the offensive supervision and control over Ottoman tribunals in cases involving foreigners which has hitherto been exercised by the consular dragoman.

II. The profound difference between the basic principles of Moslem jurisprudence and other systems of law is of so irreconcilable a character as to render it impossible for Turkey to enter into any international agreement defining the rights of foreigners in respect to personal status and civil capacity. ${ }^{30}$ No reciprocal arrangement in this regard would seem within the realm of possibility.

Nor for the same reason would it be feasible to attempt to prescribe the general principles which should guide the courts in the application of foreign laws which in spirit and in letter are so much out of harmony with Moslem legal precepts. The Turks themselves have recognized this difficulty by leaving to the different religious communities (Mil'let) exclusive jurisdiction in matters affecting the personal status of the members of these communities.

III. The institution of a special mixed court composed of native and foreign judges similar to the courts in Egypt with full and final powers, as suggested by Mandelstam, ${ }^{31}$ is open to serious objection. It would be entirely offensive to the national pride of the Turks as a most humiliating form of international intermeddling which would ultimately threaten to ex-

${ }^{30}$ Bonfils, sections $1747-1753$.

31 . Tandelstam, pp. 268-27o. 
tend to all matters involving both foreigners and natives. An international tribunal functioning inclependently within a sovereign independent state would constitute a constant menace to its independence and sovereignty.

IV. The way out of the dilemma would seem clearly to lie in a frank recognition of the clesirability of leaving to the exclusive jurisdiction of the consular courts all questions regarding foreigners which do not in any way affect the public law and order of the Empire.

The Ottoman courts would be relieved of the embarrassment of attempting to ascertain and apply foreign laws not in harmony with Moslem legal precepts. $^{32}$

The perpetuation and unobtrusive functioning of the consular courts within well defined limits would thus prove a blessing to the Turkish courts, and facilitate most effectively the ends of justice. This would require, of course, that full faith and legal effect should be given to the decisions of the consular courts.

As matters stand now, where no international agreements exist in respect to the juridical rights of foreigners, it seems unreasonable and repugnant to justice to leave to a judge, say of France, the duty of determining the exact nature and effect of a law affecting a Japanese, when the public law and order of France is in no way involved.

${ }^{32}$ Sir Travers Twiss in his Law of Nations (vol. I, p. 469), expresses the opinion that the suppression of the régime of the Capitulations would be a positive wrong to the Turks. 
In actual practice, a judge in such an instance may: ( I) call in so-called experts to advise the court concerning the law to be applied; (2) he may make request by means of letters rogatory direct to the competent foreign judicial authorities; (3) he may even apply to the consular representative of the foreigner concerned in the suit. ${ }^{33}$

In principle, there does not seem to exist any sound reason why a court should not only appeal to a consul for such information, but should even request that official to decide the actual question at issue, provided, of course, that he were empowered by treaty to perform judicial functions of this character. In the case of Goddard versus Luby, quoted by Stowell in Consular Cases and Opinions, where suit was brought for "slanderous words," the United States Court held that under the treaty then in force with France, jurisdiction belonged to the French consul of that district. ${ }^{34}$

A consul, as a matter of fact, actually does perform many acts of a more or less juridical character in the drawing up of papers, the settlement of estates of deceased fellow-countrymen, etc. $\mathrm{He}$ has extended powers of jurisdiction on board merchant vessels flying the flag of his country. These powers are conceded to him under the fiction of exterritoriality, a merchant vessel being consiclered as a floating portion of the country of the flag it flies.

${ }^{33}$ Fiore, op. cit., pp. 285-291.

34 For an excellent résumé of the polwers of Consuls, see Stolwell's Consular Cases and Opinions, under head of Compendium, pp. 739-748. See also Moore's Digest, vol. II, sec. 205$208 ; \mathrm{V}$, sec. $696-733$. 
It has been remarked that "one invents fictions when one does not know how to justify rules which are perceived to be necessary." 35 It would seem just as logical by analogy that if merchant vessels are not to be considered as having come fully within local jurisdiction for all purposes, foreigners sojourning on shore likewise should not be considered as fully subject to local jurisdiction in all that may in no way concern public law and order.

It would seem more in consonance with modern conceptions of the respect due to the rights of foreigners in the intercourse of nations, as well as more in accord with the ends of justice, to give to consular representatives judicial powers wherever foreign laws are to be interpreted and applied without injury to the interests and rights of the territorial sovereign.

An arrangement of this nature might not appear necessary or desirable where countries have similar laws and judicial procedure, and particularly where they have agreements such as have already been signed by certain of the European nations in respect to the rights of aliens.

In the case of countries having essentially different laws and procedure, such as China and Germany, England and Italy, or the United States and Turkey, the arrangement suggested would seem eminently desirable.

An agreement of this character which would necessarily be reciprocal in effect, would offend the na tional pride of no one. In harmony with the most 35 Pillet, Principes, etc., p. 258 . 
enlightened concepts of international law and intercourse, this solution would afford, in the case of Turkey, a reasonable working hypothesis to justify the perpetuation, in a much modified form, of an extraordinary régime which has been in many respects ineffective and intolerable.

The germ of such an adjustment already exists among the Chinese in the United States. Owing to the incongruities of Chinese and American law, they are unwilling to have recourse to the American courts. They therefore maintain a kind of unofficial, judicial system of their own whereby their disputes are judged and settled by their own representatives according to Chinese laws and customs.

It would not seem unreasonable or Quixotic to express the belief that such an institution should be replaced by consular tribunals properly empowered by treaty to exercise judicial functions wherever the public law and order of the territorial sovereign is in no way affected. The decisions of such courts, moreover, should be given the same respect and have the same legal effect as in the case of the decisions of foreign courts which may be entitled to recognition and execution by the courts of the territorial sovereign:

The suggestion here presented may seem on first consideration radical and offensive, even, to those who hold jealously to the exchusive rights of jurisdiction by the territorial sovereign. Under the theory, however, that "what the King permits, he commands," they might be willing to concede that the local sovereign could properly consent to judicial jurisdiction by consular courts within properly defined limits. 
From the point of view of international law, there does not seem to exist any sound objection to this proposed consecration of judicial jurisdiction by consular courts. On the contrary, such an enlightened arrangement between countries having distinct systems of law and procedure would seem better calculated to facilitate international intercourse, and more adequately protect the sacred rights of foreigners than the present unsatisfactory arrangement. All that is required to effect this reform would be the extension by treaty agreements of powers already possessed in embryo by consular officials throughout the world.

In the case of Turkey, it would mean simply the perpetuation of the existing consular court with considerably restricted powers of jurisdiction; and a clear delimitation of the respective spheres of these tribunals and Ottoman courts. Turkey could then feel that the presence of these foreign tribunals was no longer in derogation of its sovereign rights.

Recalling with pride that the privileges voluntarily and generously granted to foreigners and Christian subjects alike, were granted when the Turks were at the height of their military power, the descendants of the race of Osman might well claim with equal pride that the continuation of these greatly modified immunities of jurisdiction might properly be regarded, as suggested in the introduction, "as evidence of a more enlightened and more liberal interpretation of the law of nations than has yet been granted in Europe, the place of its origin, though not of its exclusive development or application." 


\section{APPENDIX}

REGULATIONS IN FORCE IN THE CONSULAR COURTS OF THE UNITED STATES IN THE OTTOMAN DOMINIONS.

\section{I.-Ordinary Civil Proceedings}

I. Civil proceedings between American citizens must commence by written petition verified by oath before the consul.

2. Ordinary personal civil actions are of three classes, viz:

Contract-coinprising all cases of contract or debt.

Wrong-when damages are claimed for a wrong.

Replevin-when possession of a specific article is claimed.

3. In contract, the petition must aver that payment or a performance of the conditions of the contract has been demanded and withheld; and in replevin, that the articles to be replevied have been demanded.

4. The petitioner shall be required to deposit a reasonable sum to defray the probable expenses of court and defendant's costs. Subsequent deposits may be required, if found necessary.

5. Upon deposit of the money, the consul shall order notice on the petition in writing, directing defendant to appear before him at a given day and hour to file his written answer on oath.

6. Notice must be served on each defendant at least five days before return day, by delivery of an attested copy of the petition and order and of any accompanying account or paper.

7. Personal service should always be required when practicable.

8. On proof of due notice, judgment by default shall be pronounced against any defendant failing to appear 
and file his answer as required; but the default may be taken off for good cause, within one day after (exclusive of Sunday).

9. But in actions of wrong and all others where the damages are in their nature unliquidated and inclefinite, so that they cannot be calculated with precision from the statements of the petition, the amount of the judgment shall be ascertained by evidence, notwithstanding the default.

ro. If defendant appears and answers, the consul, having both parties before him, shall, before proceeding farther, encourage a settlement by mutual agreement or by submission of the case to referees agreed on by the parties, a majority of whom shall decide it.

I I. Parties should at the trial be confined as closely as may be to the averments and denials of the statement and answer, which shall not be altered after filing except by leave granted in open court.

12. On application of either party and advance of the fees, the consul shall compel the attendance of any witness within his jurisdiction, before himself, referees, or commissioners.

I3. Each party is entitled, and may be required, to testify.

14. Judgment may be given summarily against either party failing to obey any order or decree of the consul.

\section{ATTACHMENT AND ARREST}

15. For sufficient cause and on sufficient security, the consul, on filing a petition, may grant a process of attachment on any defendant's property to a sufficient amount, or of arrest of the person of any defendant not a married woman, nor in the service of the United States under commission from the Presiclent, nor otherwise exempted by law.

I6. Any defendant may at any time have the attachment dissolved by depositing such sum or giving such security as the consul may require.

17. Perishable property, or such as is liable to serious depreciation under attachment, may, on petition of either 
party, be sold by the consul's order and its proceeds deposited in the consulate.

I8. Any defendant arrested or imprisoned on civil petition shall be released on tender of a sufficient bond, deposit of a sufficient sum, or assignment of sufficient property.

I9. Any person under civil arrest or imprisonment may have his creditor cited before the consul to hear a disclosure of the prisoner's affairs under oath, and to question him thereon, and if the consul shall be satisfied of its truth and thoroughness, and of the honesty of the debtor's conduct toward the creditor,. he shall forever discharge him from arrest upon that debt, provided the prisoner shall offer to transfer and secure to his creditor the property disclosed or sufficient to pay the debt, at the consul's valuation.

20. The creditor must advance to the jailer his fees and payment for his prisoner's board until the ensuing Monday, and afterwards weekly, or the debtor will be discharged from imprisonment and future arrest.

\section{EXECUTION}

21. On the second day after judgment (exclusive of Sunday) execution may issue enforcing the same, with interest at 12 per cent. a year, against the property and person of the debtor, returnable in 30 days and renewable.

22. Sufficient property to satisfy the execution and all expenses may be seized and sold at public auction by the officer after due notice.

23. Property attached on petition and not advertised for sale within ten days after final judgment shall be returned to the defendant.

24. When final judgment is given in favor of defendant, his person and liberty are at once freed from imprisonment or attachment, and all security by him given discharged. And the consul may, at his discretion, award him compensation for any damage necessarily and directly sustained by reason of such attachment, arrest, or imprisonment. 


\section{EXEMPTION AND DISCIIARGE}

25. The consul may exempt from attachment, seizure, or assignment any articles of personal property indispensable to the comfort of the owner or his family, and he may at any time release or bail any debtor, discharge any security or dissolve the whole, or a part, of any attachment, when justice requires.

\section{OFFSET}

26. In actions of contract, defendant may off set petitioner's claim by any contract claim, filing his own claim under oath with his answer. Petitioner shall be notified to file his answer seasonably on oath, and the two claims shall then be tried together and but one judgment given for the difference, if any provided, in favor of either party; otherwise for defendants' costs.

\section{$\cos \mathrm{T}$}

27. Except as hereinafter provided, the party finally prevailing recovers costs, to be taxed by him and revised by the consul.

\section{TRUSTEE PROCESS}

28. In contract, the consul may order defendant's property or credits in a third party's hands within the jurisdiction of the United States to be attached on the petition, by serving him with due notice as trustee, provided petitioner secures trustee his costs by adequate special deposit.

29. If adjuclged trustee, the third party may retain his costs from the amount for which he is adjudged trustee, if sufficient ; otherwise, the balance of trustee's costs must be paid out of petitioner's special deposit, as must the whole of his costs if not adjudged trustee.

30. The amount for which a trustee is charged must be inserted in the execution and clemanded of him by the officer within ten days after judgment, or all claim on him ceases. Process against the property or person of trustee may issue ten days after demand. 
3I. If petitioner recovers judgment for less than $\$$ Io, or if less than $\$ 10$ of defendant's property or credits is proved in the third party's hands-in either case the third party must be discharged, with costs against petitioner.

\section{REPLEVIN}

32. Before granting a writ of replevin, the consul shall require petitioner to file a sufficient bond, with two responsible sureties, for double the value of the property to be replevied, one an American citizen, or petitioner may deposit the requires amount.

$$
\text { II.-TENDER, ETC. }
$$

33. Before a creditor files his petition in contract, his debtor may make an absolute and unconditional offer of the amount he considers due by tendering the money in the sight of the creditor or his legal representative.

34. If not accepted, the debtor shall, at his own risk and paying the charges, deposit the money with the consul, who shall receipt to him and notify the creditor.

35 . It shall be paid to the creditor at any time if demanded, unless previously withdrawn by the depositor.

36. If the depositor does not withdraw his deposit, and upon trial is not adjudged to have owed petitioner at the time of the tender more than its amount, he shall recover all his costs.

\section{OFFER TO BE DEFAULTED}

37. At any stage of a suit in contract or wrong, defendant may file an offer to be defaulted for a specific sum and the costs up to that time, and if the petitioner chooses to proceed to trial, and does not recover more than the sum offered and interest, he shall pay all defendant's costs arising after the offer, execution issuing for the balance only.

\section{III.-REFERENCE}

38. When parties agree to a reference, they shall immediately file a rule and the case be marked "Referred"; 
a commission shall then issue to the referees, with a copy of all papers filed in the case.

39. The referees shall report their award to the consul, who shall accept the same and give judgment and issue execution thereon, unless satisfied of fraud, perjury, corruption, or gross error in the proceedings.

40. In cases involving more than $\$ 500$, if his acceptance is withheld, the consul shall at once transmit the whole case, with a brief statement of his reasons and the evidence therefor, to the minister resident, who shall give judgment on the award or grant a new trial before the consul.

\section{IV.-APPEAL}

4I. Appeals must be claimed before three o'clock in the afternoon of the day after judgment (excluding Sunday), but in civil cases only upon sufficient security.

42. Within five days after judgment, the appellant must set forth his reasons by petition filed with the consul, which shall be transmitted as soon as may be through the consul-general to the minister, with a copy of the docket entries and of all papers in the case.

43. The consul-general may allow any prisoner (by law entitled to appeal) sent to Constantinople for imprisonment on sentence of a consul, to file his appeal within ten days after notice of his arrival, if in lis judgment justice would be promoted thereby, requiring such prisoner to file with the appeal his petition, which shall be at once transmitted to the minister.

\section{V.-NEW TRIAL}

44. On proof of the perjury of any important witness of the prevailing party upon a material point affecting the decision of a suit, the consul who tried it may within a year after final judgment grant a new trial, on such terms as he may deem just.

45. Within one year after final judgment in any suit involving not more than $\$ 500$, the consul who tried it, or his successor, may upon sufficient security grant a new trial, 
when justice manifestly requires it; if exceding $\$ 500$, with concurrence of the minister.

\section{VI.-Habeas corpus}

46. No consul shall recognize the claim of any American citizen to hold any person in slavery or bondage within the Turkish Empire.

47. Upon application of any person in writing and under oath, representing that he or any other person is enslaved, unlawfully imprisoned, or deprived of his liberty by any American citizen within the jurisdiction of a consul, such consul or the consul-general may issue his writ of habeas corpus directing such citizen to bring said person, if in his custody or under his control, before him, and the question shall be determined summarily, subject to appeal.

\section{VII.-Divorce}

48. Libels for divorce must be signed and sworn to before the consul, and on the trial each party may testify.

49. The consul, for good cause, may order the attachment of libellee's property to such an amount and on such terms as he may think proper.

50. He may also, at his discretion, order the husband to advance to his wife or pay into court a reasonable sum to enable her to prosecute or defend the libel, with a reasonable monthly allowance for her support pending the proceedings.

5I. Alimony may be awarded or denied the wife on her divorce at his discretion. Custody of the minor children may be decreed to such party as justice and the children's good may require.

52. Divorce releases both parties, and they shall not be remarried to each other.

53. Costs are at the discretion of the consul.

\section{VIII.-MARRIAGE}

54. Each consul shall record all marriages solemnized by him, or in his official presence, and at the end of each year transmit a copy to the Secretary of State and to the consul-general. 


\section{IX.-BIRTHS AND DEATHS}

55. The birth and death of every American citizen o; protégé within the limits of his jurisdiction shall likewise be recorded and annually transmitted.

\section{X.-List of citizens and protegés}

56. Each consul shall prepare and keep a correct list of all adult male citizens of the United States living within his jurisdiction, with their age, birthplace, occupation, residence, and year of arrival in Turkey, and the names, $\& c$, of the members of their families; adding the date and court in case of naturalized citizens.

57. Also a similar list of all protegés of the United States, adding the year of their original protection, by whom it was granted, and where; also the date of their last permit of residence and by whom issued.

58. A copy of said lists shall be transmitted to the Secretary of State, to the minister resident and to the consulgeneral, when completed, and a memorandum of the changes at the end of each year. And every citizen and protegé is required to register himself and family at the consulate each December.

XI.-Bankruptcy, partnership, probate, \&.

59. Until promulgation of further regulations, consuls will contint:e to exercise their former lawful jurisdiction and authority in bankruptcy, partnership, probate of wills, administration of estates, and other matters of equity, admiralty, ecclesiastical and common law not specially provided for in the foregoing orders, according to such reasonable rules, not repugnant to the Constitution, treaties, and laws of the United States, as they may find necessary or convenient to adopt.

\section{XII.-SEAMEN}

60. In proceedings or prosecutions instituted by or against American seamen, the consul may, at his discretion, suspend any of these rules in favor of the seaman, when, in his opinion, justice, humanity, and public property may require it. 


\section{XIII.-CRIMINAL PROCEEDINGS}

6I. Complaints and information against American citizens should always be signed and sworn to before the consul, when the complainant or informant is at or near the consul's post.

62. All complaints and informations not so signed and sworn to by a citizen of the United States, and all complaints and informations in capital cases, must be authenticated by the consul's certificate of his knowledge or belief of the substantial truth of enough of the complaint or information to justify the arrest of the party charged.

63. No citizen shall be arraigned for trial until the offense charged is distinctly made known to him by the consul in respondent's own language; in cases of magnitude, and in all cases when demanded, an attested copy (or translation) of the complaint, information, or statement authenticated by the consul shall be furnished him in his own language as soon as may be after his arrest.

64. The personal presence of the accused is indispensable throughout the trial.

65. He shall always have and be informed of his right to testify, and cautioned that if he chooses to offer himself as a witness, he must answer all questions that may be propounded by the consul or his order, like any other witness.

66. The government and the accused are equally entitled to compulsory process for witnesses within the jurisdiction of the United States; and if the consul believes the accused unable to advance the fees, his necessary witnesses shall be summoned at the expense of the United States.

67. When punishment is by fine, costs may be included or remitted at the consul's discretion; an alternative sentence of not less than 30 days' imprisonment may take effect on non-payment of any part of the fine or costs adjudged in any criminal proceeding.

68. Any prisoner before conviction may be admitted to bail by the consul who tries him, except in capital cases.

69. No prisoner charged with a capital offense shall be 
admitted to bail where the proof is evident or the presumption of his guilt great.

7o. After conviction and appeal, the prisoner may be admitted to bail only by the minister or consill-general.

$7 \mathrm{r}$. Any citizen of the United States offering himself as bail shall sign and swear before the consul to a schedule of unemcumbered property of a value at least double the amount of the required bail.

72. Any other proposed bail or security shall sign and swear before the consul to a similar schedule of unemcumbered personal property within the local jurisdiction of the consulate, or he may be required to deposit the amount in money or valuables with the consul.

73. Unless such sufficient citizen becomes bail, or such deposit is made, at least two sureties shall be required.

74. Any American bail may have leave of the consul to surrender his principal on payment of all costs and expenses.

75. Any complainant, informant, or prosecutor may be required to give security for all costs of the prosecution, including those of the accused; and every complainant, \&c., not a citizen of the United States shall be so required, unless in the consul's opinion, justice will be better promoted otherwise; and when such security is refused the prosecution shall abate.

\section{HONORABLE ACQUITTAL}

76. When the innocence of the accused both in law and in intention is manifest, the consul shall add to the usual judgment of acquittal, the word, "Honorably."

77. In such case judgment may be given and execution issued summarily against any informer, complainant, or prosecutor for the whole costs of the trial, including those of the accused, or for any part of either or both, if the proceeding appears to have been groundless and vexatious, originating in corrupt, malicious, or vindictive motives.

78. Consuls will ordinarily encourage the settlement of all prosecutions not of heinous character by the parties aggrieved or concerned. 


\section{XIV.-OATHS}

79. Oaths shall be administered in some language that the witness understands.

80. A witness not a Christian shall be sworn or examined according to his religious belief.

8I. An avowed atheist shall not be sworn, but may affirm under the pains and penalties of perjury, the credibility of his evidence being for the consideration of the cousul.

82. A Christian conscientiously scrupulous of an oath may affirm under the pains and penalties of perjury.

$$
\text { XV.-DOCKETS, RECORDS, \&.C. }
$$

83. Each consul shall keep a regular docket or calendar of all civil actions and proceedings, entering each case separately, numbering consecutively to the end of his term of office, with the date of filing, the names of the parties in full, their nationality, the nature of the proceeding, the sum or thing claimed, with minutes and dates of all orders, decrees, continuances, appeals, and proceedings until final judgment.

84. He shall keep another regular docket for all criminal cases with sufficient similar memoranda.

85. Upon final judgment each case shall be recorded in a book of records, at sufficient length to identify it and prevent a second proceeding for the same cause.

86. Civil proceedings are to be kept distinct from criminal and recorded in separate books, and returns of each made to the consul-general at the end of each year.

87. Each clocket and book of records shall contain an index.

88. All original papers shall be filed at once and never removed; no person but an officer of the consulate or the minister should be allowed access to them; all papers in a case must be kept together in one inclosure and numbered as in the clocket with the parties' names, the nature of the proceeding, the year of filing the petition and of final judgment conspicuously marked on the inclosure and each year's cases kept by themselves in their order. 
XVI.-Limitation of actions and prosecutions

89. Heinous offenses, not capital, must be prosecuted within six years; minor offenses within one.

90. Civil actions based on written promise, contract, or instrument must be commenced within six years after the cause of action accrues; others within two.

91. In prosecutions for heinous offenses, not capital, and in civil cases involving more than $\$ 500$, any absence of respondent or defendant for more than three months at a time from Turkey shall be added to the limitation; and in civil cases involving more than $\$ 100$ the period during which the cause of action may be fraudulently concealed by defendant shall likewise be added.

92. No action in contract, replevin, or wrong shall be commenced for less than $\$ 5$, no trustee process for less than $\$ 10$, no property attached for less than $\$ 25$, nor the person arrested for less than $\$ 50$; and if petitioner recovers less than the respective amount in either case, he shall pay all costs unless for special reasons to the contrary.

\section{XVII.-General PROVISIONS}

93. All trials and proceedings in the United States consular courts in Turkey shall be open and public and conducted in the English language.

94. Papers and testimony in a foreign language shall be translated into English by a sworn interpreter appointed by the consul; in civil cases to be paid by petitioner. Oaths and questions shall be translated by the interpreter from the English for any witness who does not understand English.

95. Parties may be required to file their petitions, answers, complaints, informations, and all other papers addressed to the court, in English, or they may be translated by the interpreter, at the consul's discretion. All testimony must be taken in writing in open court by the consul or his order signed by the witness after being read over to him for his approval and correction, and it shall form part of the papers in the case.

96. The consul may adjourn his court from time to 
time and place to place within his jurisdiction, always commencing proceedings and giving judgment at the consulate.

97. The first Monday of each month shall be a regular court day to which civil actions will stand adjourned unless otherwise provided for.

98. No court shall sit on February 22, July 4, December 25 , or on any Sunday.

99. All processes not served by the consul personally must be executed by an officer of the consulate, who shall sign and swear to his return before the consul, specifying the time and mode of service and annexing an account of his fees; process from the consul-general shall be served by the marshal of his deputy.

Ioo. On appeal, copies of all the papers must be paid for in advance by the appellant, except in criminal cases where respondent is unable to pay.

IOI. Any person interested is entitled to a copy ot any paper on file on prepayment of the fee.

IO2. Reasonable clearness, precision, and certainty should be required in the papers, and substantial justice and all practicable dispatch is expected in the decisions; but technical accuracy is not essential.

I03. The word "consul" is intended to include the consul-general and any vice-consul or deputy consul actually exercising the consular power at any consulate, unless the sense requires a more limited construction.

I04. Each associate in a consular trial shall, before entering on his duties, be sworn by the consul. Before taking the oath, he may be challenged by either party and for sufficient cause excused and another drawn.

105. Consuls will always preserve order in court, punishishing summarily any contempt committed in their presence or any refusal to obey their lawful summons, or order, by imprisonment not exceeding 24 hours, or by fine not exceeding $\$ 50$, and costs.

I06. Every party to a civil or criminal proceeding may be heard in person or by attorney of his choice, or by both, but the presence of counsel shall be under exclusive control and discretion of the consul. 
I07. The accounts of the consular courts shall be kept in United States currency, and every order or deposit, decree of costs, taxation of fees, and generally every such paper issuing originally from the court, shall be expressed in dollars and cents and satisfied in United States metallic money or its equivalent coin as fixed by law.

\section{XVIII.-ProceEdings With FOREIGNERS}

I08. All petitions, informations, complaints, and other papers from subjects of the Sublime Porte, or subjects or citizens of any other friendly power, should be communicated through the Turkish authorities or the consulate of such other power.

IO9. All notices, answers, \&c., should be communicated to such subject or citizens through said authorities or such consulate, respectively.

\section{XIX.-Mixed COMmissions}

I IO. When any foreign petitioner is entitled to a mixed commission the suit shall be tried at the United States consulate or such place as the United States consul may direct, and proceedings shall be conducted as nearly as may be as in suits between citizens of the United States.

III. Every commissioner nominated by a foreign authority must have his appointment acknowledged and approved by the United States consul before taking his seat on the commission ; and all objections to the approval of the nomination or appointment of either commissioner shall be heard and determined by the consul summarily and without appeal.

I I2. The commissioner appointed by the United States consul should be a citizen of the United States, when practicable; he will always preside, and his presence is indispensable throughout the proceedings.

\section{XX.-DEsign OF TIIE RULES}

The promulgation of these rules abrogates no authority hitherton lawfully exercised by consuls not inconsistent herewith.

$$
\text { XXI.-CHANGeS }
$$

Whenever, in the opinion of the consul, a change be- 
comes necessary in the rules, the proposed change, with the reasons, shall be communicated in writing to the minister, and, the change approved by him, be submitted to the other consuls and published over his signature before going into effect.

Amendments to the foregoing Rules decreed by the Minister Resident to Constantinople, June I4, 1880

TO THE CONSULS GENERAL AND CONSULS OF THE UNITED STATES OF AMERICA IN THE OTTOMAN EMPIRE

It appearing to me that neither the common law, nor the laws of equity and admiralty, nor the Statutes of the United States furnish appropriate and sufficient remedies for the cases hereinafter mentioned and provided for, therefore I, Horace Maynard, Minister Resident of the United States at the Sublime Porte, by virtue and in pursuance of Section 4086 of the Revised Statutes of the United States, do hereby decree as follows:

Section $r$. Whenever any citizen of the United States shall have died leaving any personal estate within the territorial jurisdiction of any Consular officer of the United States appointed to reside in the Ottoman Empire, and such death having occurred in any country or place, not within such Consular jurisdiction, then such Consular officer shall be invested with and have the same powers and duties in relation to and over such personal estate as are given by section I 709 of the Revised Statutes to such Consular officer in relation to and over the personal estates of citizens of the United States who shall have died within his Consulate.

Section 2. The words "Consular Officer of the United States" as used in the next preceding Section are meant to include the Agent and Consul General at Cairo, the Consul General at Constantinople, and the vice consuls general, the consuls and vice consuls appointed to reside in the Ottoman Empire, and no others.

Section 3. The following consular officers to wit, said Agent and Consul General and said Consuls General and Consuls shall each have the power, whenever in his 
opinion it is necessary, to appoint an administrator or administrators to take charge of and administer such personal estate of any deceased citizen of the United States as shall be within the territorial jurisdiction of the officer making such appointment giving to such administrator or administrators and investing him or them with all the powers, and imposing upon him all the duties and obligations in relation to such estates as might have been exercised by or would have devolved upon such consular officer.

Section 4. Such Agent and Consul-General, ConsulGeneral, and Consuls shall each also have the power to appoint a guardian or guardians to take charge of the property and persons and to protect the rights of any infant being a citizen of the United States and having property or being himself within the territorial jurisdiction of such consular officer, giving to such guardian or guardians all necessary power and authority to fulfill their duties as such.

Section 5. In the case of the appointment of any administrator or guardian under the foregoing Sections 3 and 4 , it shall be the duty of the officer making such appointment to require of and take from such administrator or guardian such surety for the faithful performance of his duties as such officer shall deem adequate; and such officer shall also have the power to compel such administrator or guardian to render from time to time as he may require an account of his proceedings and to disburse and pay over any and all moneys in his hands as he, the said consular officer shall direct.

In testimony whereof the said Horace Maynard, Minister Resident as aforesaid (L.S.) hath hereunto set his hand and caused the seal of the Legation to be affixed at the Legation of the United States at Constantinople, this, the I $4^{\text {th }}$ day of June A.D. 1880 .

Horace Maynard.

By the Minister Resident,

G. H. HeAp,

Secretary of Legation. 


\section{SELECTED BIBLIOGRAPHY}

Period Prior to I453

General Works:

Gibbon, Edward, The History of the Decline and Fall of the Roman Empire, with notes by the Rev. H. H. Milman. Edition by A. L. Burt Company, New York.

Hautefeuille, Laurent B., Histoire de Droit Maritime International. Paris, I858.

Heyd, Wilhelm, Histoire du Commerce du Levant, etc. Leipzig, I 885-I 886 .

Miltitz, Alexandre de, Manuel des Consuls. London and Berlin, I $837-1842$.

Pardessus, J. M., La Collection des lois maritimes anterieures au XVIII. siècle. Paris, I838-1845. Imprimerie royale.

Warden, D. B., The Origin, Nature and Influence of Consular Establishments. Paris, I8I3.

Special Works:

Amari, Michele, Dai Diplomi Arabi, etc. Firenze, 1863.

Daru, Pierre, Historia della Republica di Venezia. Paris, I82I.

Marin, Carlo Antonio, Storia civile é politica del commercio de Veneziani. Venezia, I798-ı808.

Muratori, Ludovico A., Rerum Italicarum Scriptores. Citta de Castello, Igoo.

Paris, Louis, Chronique de Nestor. Paris, 1834I835.

Primaudaie, F., Elie de la, Les Arabes en Sicilie et en Italie. Paris, I868.

Sauli, Lodovico, Della Colonia de Genovesi in Galata. Turin, I83I. 
Scott, S. P., History of the Moorish Empire in Europe. Philadelphia and London, 1904.

Wenrich, Johann Geor., Rerum ab Arabis in Italia, etc. Leipzig, 1845 .

Period Subsequent to 1453

General Works:

Charrière, Ernest, Negotiations de la France dans le Levant, etc. Paris, I848-1860.

Eliot, Sir Charles (Odysseus), Turkey in Europe. London, I900.

Flassan, M. de, Histoire Generale et Raisonnée de la Diplomatie Française, etc. Paris, I809.

Hammer, Joseph, Freiherr von, Geschichte des Osmanischer Reichs. Pest, Wien, I827-I 835.

Pears, Sir Edwin, Turkey and its People. London, 1912. (2l. ed.)

Special Works:

"Ancien Diplomat," Le Regime des Capitulations. Paris, I 898.

- Angell, James B., Turkish Capitulations. Annual Report of American Historical Association for 1900.

Belin, Francois Alphonse, Des Capitulations et des Traités de la France en Orient. Paris, 1878.

Brunswik, Benoit, Etudes Pratiques sur le Question d'Orient, Reforms et Capitulations. Paris, 1869.

Engelhardt, Edouard, La Turquie et le Tanzimat. Paris, I 882-I 884.

Hall, W. E., Foreign Jurisdiction of the British Crown. Oxford, 1894.

Hinckley, F. E., American Consular Jurisdiction in the Orient. Washington, I9o6.

Mandelstam, André, La Justiée Ottoman dans se; Rapports avec les Puissances Etrangères. Paris, I9I I. (2d. ed.)

Moore, John Bassett, International Law Digest (under Exterritoriality). Washington, I906. 
Piggott, Sir Francis T., Exterritoriality. London, I892.

Rausas, Pelissié du, Le Regime des Capitulations dans L'Empire Ottoman. Paris, 1910. (2d. ed.)

Tarring, Judge C. J., British Consular Jurisdiction in the East. London, I887.

Van Dyck, Edward A., Report on the Capitulations of the Ottoman Empire. In two Parts: Senate Ex. Doc. 3. Special Session of 46th Congress; and Senate Ex. Doc. No. 87, ist Session, 47th Congress. Wharton, Francis, International Law Digest (under Exterritoriality). Washington, I887. (2d. ed.)

Turkish Laws and Usages:

Aristarchi, Gregorios, Legislation Ottomane. Constantinople, I873-1888.

D'Ohsson, Mouradjea, Tableau General de L'Empire Ottoman. Paris, I788-1824.

Gatteschi, D., Manuale de Diritto Ottomano, etc. Alexandria, Egypt, 1865.

Rodwell, J. M., The Koran. London and New York, 1909. (Everyman's Library.)

Steen de Jehay, F. M. J. G. van den, De la situation legale des sujets Ottomans non-musulmans. Brussels, 1906.

Young, George, Corps de Droit Ottoman. Oxford, 1905-1906.

Treaties:

Elliot, Jonathan, The American Diplomatic Code, etc., Washington, I834.

Hertslet, Sir Edward, Treaties in Force. London, I875.

Malloy, W. M., Treaties, etc., of the United States. Washington, I910.

Martens, F. F., Receuil des Traités, etc. St. Petersburgh, I874.

Noradounghian, Gabriel, Receuil d'actes internationaux de l'Empire Ottoman, etc. Paris, I897-1900.

Testa, Barons Alfred and Leopold de, Receuil des Traités, etc. Paris, I864-I9II. 
International Law Publicists:

Bonfils, Henry, Manuel de Droit International Public. Paris, 1908 . (5th. ed.)

Despagnet, F., Precis de Droit International Privé. Paris, I 899. (3d. ed.)

Dicey, A. V., Conflict of Laws. London, I 896. Latest edition, London, 1908.

Fiore, Pascuale, Droit International Privé. Paris, I $890-$ I 89 .

Hall, W. E., A Treatise on International Law. (6th. ed.) Oxford, igo9.

Heffter, A. IV., Droit International Public. Berlin, Paris, 1883 .

Holland, T. E., The Elements of Jurisprudence. Oxford, igo6. ( ioth. ed.)

Holtzendorff, F. von, Handbuch des Völkerrechts. Berlin, I 885-I889.

Kent, James, Commentary on International Law. Cambridge and London, I878. (2d. ed.)

Laurent, Francois, Droit Civil International. Brussels, I 880-I 88I.

Phillimore, Sir Robert, Commentaries upon International Law. London, i 861. (3d. ed. I879-89.)

Pillet, Antoine, Principes de Droit International Privé. Paris, 1903.

Savigny, F. Karl von, Private International Law. Edinburgh, I880. (2l. ed.)

Story, Joseph, Conflict of Laws. Boston and London, I $896 . \quad$ (3d. ed.)

Twiss, Sir Travers, Law of Nations. Oxford, I884. Westlake, John, Private International Law. London, I88o. (2d. ed.) Third edition, I890.

Wharton, Francis, Conflict of Laws. Philadelphia, I872. 


\section{INDEX}

A

Actions and Prosecutions

United States Consular Court Regulations, I30

Actor sequitur forum rci

foreigners sue in consular courts of defendant in accordance with principle of, 67

Administration of Estates

U. S. Consular Court Regulations, I33

Adrianople, Treaty of (see Venice)

Afarian

arrest and trial of, by Turks, 78

Ahd-nameh

correct term for Capitulations, 29

Aliens (see Foreigners)

international law concerned with protection of rights of, IoI comitas gentium not basis of rights of, 104, II2

proper subject of international agreements, 105

Amalfi

consular court in Naples, Amalfitan Tables, I5

American Missionaries

customs exemptions of, 95

Appeals

U. S. Consular Court Regulations, I24 Arabs

exterritorial privileges of, in China, Io

exterritorial privileges of foreigners in Sicily under rule of, 24

Armenians

exterritorial privileges granted by Justinian, Io

exterritorial privileges of Patriarchate, i 8

Arbitral Award of Ambassadors of Six Powers

rights of Greece after war of 1897,4 I, 89 
Arrest

of foreigners by consular officials, 62

of foreigners by Turkish police in cases of flagrant delit, 62 of foreigners accused before Turkish courts, 90

U. S. Consular Court Regulations, 120

Article IV of United States Treaty, 41, 76

text supported by United States, 77

text supported by Turkey, 77

views of Secretary Frelinghuysen concerning, 78

test case of Vartanian and Afarian, 78

views of André Mandelstam formerly Dragoman of Russian

Embassy concerning, 79

conciliatory attitude of United States in respect to interpretation of, $8 \mathrm{I}$

Assessors

presence of foreign assessors in Mixed Commercial Tribunals, 83

restraining influence of, 88

Associates

of U. S. Consuls in criminal, capital and civil cases, 56

Attachment and arrest

U. S. Consular Court Regulations, 120

Austria-Hungary

treaty with Turkey, $4 \mathrm{I}$

consular courts of, 54

practice of, in respect to nationals sentenced by Turkish courts, 89

B

Bailo, Bajuli, Baille

Venetian magistrate, 13, 30

French magistrate, 34

Banishment

U. S. Consuls not authorized to banish American convicts, 64 Bankruptcy

within province of consular courts, 75

U. S. Consular Court regulations, 126

Barbarian, Hostis

Use of terms, 9

Belgium

treaty with Turkey, 4I 
arrest and trial of Joris, Belgium subject, by Turks, 80

claims criminal jurisdiction over nationals, 76

practice of, in respect to nationals sentenced by Turkish courts, 89

Births and deaths

U. S. Consular Court Regulations, I26

Bourée

Real Estate Protocol drawn up by, French Ambassador, 94 Brazil

treaty with Turkey, 4I

British (see England)

Byzantium

treaty with Warings of Russia, II

$\mathrm{C}$

Cadiz

exterritorial privileges of foreign merchants in, Io

Capitulations, $27-47$

use of term, 29

privileges of Franks and Catalans confirmed by Soliman, II, 32

treaty of 1535 between Soliman II and Francis I, 33

renewal of, 37

treaty of $1740,38,75$

revision of régime of, 96

Catalans

privileges of confirmed by Soliman II, 32

Cavass

arrest of foreigners by, 52

consular protégés, 93

Charlemagne

privileges obtained from Haroun-el-Raschid by, II

Chinese

method of adjusting differences without appeal to courts, I I7 Citizens

registration of, U. S. Consular Court Regulations, I26

Civil Suits and Proceedings

provisions of Capitulations of $\mathbf{1 5 3 5}$ in respect to, 34

jurisdiction by consular courts between foreigners in, 52, 67

presence of dragoman in, $24,82,84,88$

provisions of Capitulations of 1740 in respect to, 39 
Turkish Civil Code, 87

reform of Turkish laws in respect to, 112

in U. S. Consular Courts, 119

Claudius, Emperor

privileges accorded merchants in Cadiz, Io

Comitas Gentium

rights of aliens not dependent on, 104-105

Commerce

cradle of international law, 8

Mixed Commercial Tribunals, 82

presence of assessors in commercial suits, 83

Commercial Code, 87

usury not countenanced by Moslem law, 87

Conflict of Laws (see Private International Law)

Constantinople

Armenians in, Io

Venetians in, 13, 29

Genoese in, 14, 27, 29

Moslems in, 17

Consuls

use of term by U. S. Statutes, 55

police powers of, $6 \mathrm{r}$

limited police powers of American Consuls, 62

power of, to punish, 64

execution of death penalty by, 65

no power to banish, 64

various juridical acts of, 70

Consular Courts

jurisdiction of, over foreigners of same nationality, 52

jurisdiction of, in matters of inheritance, rent, mortgage, etc., 53

forms and procedure of, 54

jurisdiction of, over foreigners of different nationality, 67

lex loci often applied by, 7I

jurisdiction in matters affecting personal status, II3

jurisdiction in various matters, I I5

judicial powers which should be granted to, I 16

Consular Courts of the United States

organization and procedure of, 54-6I

rules and regulations of, $119-134$

jurisdiction of, how exercised, 60 
powers of Ministers to make regulations for, 59

powers of, to punish, 64

jurisdiction of, in divorce, $7 \mathbf{I}$

jurisdiction in criminal cases, $55,76,127$

civil jurisdiction of, 55

original jurisdiction of, 55

associates in criminal cases, 56 ; in capital cases, 56 ; in civil cases, 56

settlement of civil cases and minor offenses, 57

forms of proceedings, 57

evidence in, 57

appeals to Minister, 57

judgments final, 124

execution of judgments, 58 , I $2 \mathrm{I}$

court costs, 58, I22

no juries, $6 \mathrm{I}$

Consular Immunities

of diplomatic character, 92

customs exemptions, 92

Consular Protégés (see Protégés)

Correspondence

inviolability of, 95

for eign post-offices, 95

Costs

U. S. Consular Court Regulations in respect to, 122

Cour de Cassation

restrictions on jurisdiction of, 86

Criminal Suits and Proceedings

in cases between foreigners, 52

in cases between foreigners and natives, 36

provisions of Capitulations of 1740 in respect to, 32

claims of Turkey to jurisdiction in cases involving public law and order, 68

claims of U. S. to jurisdiction over Americans, 76

jurisdiction of Tribunaux Correctionnels, 82

reform of Turkish criminal law, II2

abandonment of jurisdiction by Powers, II2

U. S. Consular Court Regulations in respect to, 127, (see Consular Courts of the United States)

Crusaders, I5 
Customs

international servitude in respect to, 30

exemptions for religious communities, 95 ; for consuls, 92 Cyprus

nominally Turkish but enjoying special status under England, 47

Dar-ul-harb

applied to non-Moslems, 4

use of, similar to barbarian and hostis, 9

Dar-ul-Islam

applied to Moslems, 5

Denmark

treaty with Turkey, 4 I

Divorce

by American Consuls, 7I

U. S. Consular Court Regulations, I25

Djema'at

use of term, i8

Dockets, Record, etc.

U. S. Consular Court Regulations, I 29

Don Pacifico

case of, cited, 102

Domicile, Inviolability of, go

provisions of Capitulations of 1740,40

provisions of Real Estate Protocol, 45

hotels, apartments, printing establishments, bookstores,

Dragoman

liquor shops, places of amusement, etc., go

provisions of Capitulations of 1740 in respect to presence of, in suits between foreigners and natives, 24

judicial powers of, 24

presence of, in Tribunaux Correctionnels, Nizamieh, and

Mixed Tribunals, 82

usage respecting, 84

restraining influence of, 88

renunciation of powers of, II 3

E

Efrenji

applied to all Europeans, 32 
Egypt

nominally Turkish territory but enjoying special status under England, 47

Mixed International Courts, II 3

\section{Eman}

England

use of term, 4,6

right of, to adhere to Capitulations of 1535,30

treaty with Turkey, 4I

consular courts of, 54; right of Ottoman subjects to sue in, 67

British Consuls authorized to marry foreigners of different nationality, 70

practice of, in respect to nationals sentenced by Turkish courts, 89

blockade of Venezuela by, I02

reparation obtained by, in case of Don Pacifico, I02

personality of laws recognized by English in India, 24

Execution of Judgments

U. S. Consular Court Regulations, I2I

Exemption and discharge

U. S. Consular Court Regulations, I 22

Exterritoriality (see Immunities of Jurisdiction)

inadequacy of term, 3,46

foreigners do not always carry with them exterritorially their own laws, 60, 6r

\section{Extradition}

provisions of treaty between Byzantium and Warings, II

in countries under exterritorial régime, 64

of Tunstall, Myers, and Surratt, 64

proper concern of international law, IOI

$\mathrm{F}$

Foreigners (see Aliens)

origin of exterritorial rights of, 3-24

denoted as Mustcmin in Moslem lands, 6

guarantees to, by Moslem law, 4, 6

international usage concerning, prior to $\mathrm{I} 453,8-\mathrm{I} 7$

jurisdiction of consular courts in suits between, 52, 67

right of recourse to Ottoman courts, 66

provisions of Capitulations of 17 to respecting, 39

suits of, before Imperial Divan, 34, 36 
Forum delicti

American, British, and Greek judicial procedure in consular courts based on principle of, 63

France

privileges obtained for Franks by Charlemagne, II

exterritorial jurisdiction granted in Tripoli and Alexandria, I6; privileges confirmed by Soliman II, 32

Capitulations of 1535,33

Capitulations of 1740,38

extensive police powers of French Consuls, 6I

practice in respect to nationals sentenced by Turkish courts, 89

law administered in consular courts of, 57

jurisdiction of French consuls in U. S. according to decision in Goddard v. Luby, II5

Francis I

treaty with Soliman II, 33

Galata (see Genoese)

Genoese

separate town of Galata occupied by, I4

privileges obtained by, in Alexandria, 16, 27

privileges granted by Mohammed the Conqueror, 14, 27

Germany (see Prussia)

privileges enjoyed in Novgorod by Germans of Wisby, I3

practice in respect to nationals sentenced by Turkish courts, 89

blockade of Venezuela by, 102

Goddard v. Luby

case cited, II5

Greece

settlement of Greek merchants at Naucratis, 9

privileges granted Greek monks in Palestine by Omar, Io

powers of Greek Patriarchate, I8

treaty with Turkey, 4I

Arbitral Award of Ambassadors of Six Powers respecting rights of, 4I ; provisions of Award respecting Greeks sentenced by Turkish courts, 89

reparation obtained from, in case of Don Pacifico.

Guardianship

U. S. Consular Court Regulations, I34 
$\mathrm{H}$

\section{Habeas Corpus}

U. S. Consular Court Regulations, I 25

Hanseatic League

exterritorial privileges of merchants of, I4

Haradj

use of term, 5, I9

Hedjaz

foreigners not allowed to own land in, 42

Holland

treaty with Turkey, 4I

practice in respect to nationals sentenced by Turkish courts, 89

Hostis (see Barbarian)

\section{I}

Immunities of Jurisdiction (see Exterritoriality)

origin of, 3-24

privileges granted by treaty between Byzantium and Warings

of Russia, II

originally common practice and not anomalous, I3

modifications of, in Turkey, $4 \mathrm{I}, 96$

relation of, to international law, IoI-I I8

Immunities of Jurisdiction in Cases Involving Foreigners of

Same Nationality, 52-66

jurisdiction of consular courts, 52

procedure of consular courts, 52

law administered by, 59

execution of law, $6 \mathrm{I}$

arrest of foreigners, 62

imprisonment of foreigners, 63

remanding of convicted foreigners to native land, 64

execution of death penalty, 65

Immunities of Jurisdiction in Cases Involving Foreigners of

Different Nationalities, 66-7 I

jurisdiction of consular courts, 66,67

defendant may not bring cross-suit in own consular court, 69

law administered and executed, 69

right of foreigners to sue in Turkish courts, 66

jurisdiction of British courts over foreign defendants, 67 
claim of Porte to jurisdiction in cases affecting public law and order, 68

principle of locus regit actum applied by consular courts, 70 various juridical acts of consuls, marriage, etc., zo

Immunities of Juriscliction in Matters Affecting Both Foreigners and Ottoman Subjects, 75-90

jurisdiction of Turkish courts, 75

jurisdiction in criminal cases claimed by U. S., 76

courts and procedure, $8 \mathrm{I}$

presence of Dragoman in Turkish courts, 85

presence of assessors, 83,88

summons and sentences of Turkish courts, 86

law administered, 87

execution of law, 89

Imperial Dizan (see Porte)

diplomatic adjustment of judicial questions by, 39, 76

Imprisonment

in Turkish jails, 63

in native land for appeal or punishment, $6_{3}$

for debt, 90

practice in respect to foreigners sentenced by Turkish courts, 89

India

personality of laws recognized by British in, 24

Inheritance

jurisdiction in cases of, claimed by consular courts, 53,75

International Law

protection of aliens proper concern of, IOI, IO2

status of individuals under, Ior

relation of Private International Law to, I03-I12

relation of immunities of jurisdiction to, I00-I I8

liberal interpretation of, II 8

International Private Law (see Private International Law)

Italy

consuls in London and Netherlands, I6

exterritorial privileges obtained through Venetian Capitulations, 32

powers of Italian Consuls in respect to marriage, zo

practice in respect to subjects sentenced by Turkish courts, 89

reparation on account of New Orleans riots obtained by, 102 blockade of Venezuela by, I02 
Jails

Consular, 63

Turkish, 63, 90

Jerusalem

special privileges of foreigners in, under Crusaders, I5

Jews

representative of Grand Master of Rhodes in, 16

attitude of Koran towards, 5

exterritorial privileges granted to, by Turks, 7 Joris

arrest and trial of Belgian subject by Turks, 80

Judicial Reforms, 76

modifications of exterritorial rights after, 36

Juridical Acts

in accordance with local usage, 60

various acts performed by consuls, 7o

Juridical Rights of Foreigners, 5I-97

not based on any single treaty, $5^{\mathrm{I}}$

Jury

none in trials by U. S. Consular Courts, 6I

Justinian

grants privileges to Armenians in Constantinople, Io

$\mathrm{K}$

Kiafir-Kitaby

Koran

applied to Christians and Jews, 5, 2I

concerning infidels, 5

concerning Jews, Sabeites and Christians, 5

$\mathrm{L}$

Land, Ownership of (see Real Estate)

Letters Rogatory

employed by courts in ascertaining foreign law, II5

Lex Loci

as applied by consular courts, $7 \mathrm{I}$

Locus Regit Actum

consular courts recognize principle of, 60 , 61 
Marriage

by consuls, iI

international agreements concerning, I05

governed by local laws, 60

U. S. Consular Court Regulations in respect to, 125

Medjelle

Ottoman Civil Code, based on Sheri, 87

Military Exemption

Mivlet

of non-Moslems, 19, 20

creation by Mohammed the Conqueror, 18

independent religious communities, 19

recognized as nations by Young Turks, 20

exclusive jurisdiction in matters affecting personal status, II 3

Minister

Mirzan

use of term in U. S. Statutes, 55

sentenced to death in Alexandria by American Minister, 65 Missionaries

customs privileges of, 95

Mixed Commissions

U.S. Consular Court Regulations, I32

Mohammed, The Conqueror

-policy of, towards conquered Greeks, I8; in harmony with

Moslem system of jurisprudence, 23

privileges granted to Genoese of Galata, 14, 27

Mohammed, The Prophet

attitude towards non-Moslems, 5

Moors

respected local laws in Spain, 24

Mortgage

jurisdiction of consular courts in questions relating to, 53

Moslems

attitude of, towards foreigners, $4-8$

jurisprudence, codes, etc., 6

no irreconciliable hostility between Moslem law and international law, 8

in Jerusalem, 15

in Corsica and Sicily, 16

in Constantinople before 1453,17 
conflict between Moslem jurisprudence and other systems in respect to personal status, II 3

Sheri basis of all Moslem law, 21, 87

usury not countenanced by Moslem law, 87

Most-Favored-Nation

exterritorial rights of various nations granted to each and all through principle of, 38, 41

Multeka-ul-ebhar

Moslem Code drawn up by Sheikh Ibrahim, 6

Mushrikin

as applied to pagans and idolators, 5

\section{Mustemin}

applied to foreigners in Moslem lands, 6

Myers

applied also to Moslems in foreign lands, 7

forcible extradition from Morocco, 64

$\mathrm{N}$

Naturalization

not recognized by Turks without express permission, 42 New Trial

U. S. Consular Court Regulations, I24 $N i z a$

as interpreted by Turks in limited sense, 68

Nizamieh Tribunals jurisdiction of, 82

Non-Moslems

attitude of Koran towards, 4, 5

guarantees of Moslem code to, 6

exempted from military service, I9

legal status of, $18-24$

not subject to Sheri law in matters of personal status, 2I

granted similar rights as foreigners by treaty, 24

Novgorod

early laws of, respecting foreigners, I5

$\mathrm{O}$

Oaths

U. S. Consular Court Regulations, I29

Off set

U. S. Consular Court Regulations, I22 
Omar, The Caliph

grants privileges to Greek Monks in Palestine, Io

Ottoman Tribunals

controversy as to juriscliction of, in matters of inheritance, rent, mortgage, trademarks, 53

right of foreigners to sue in, 54

jurisdiction of, in matters affecting foreigners and natives, 75

Tribunaux Correctionnels, 82

Nizamich Tribunals, 82

Mixed Commercial Tribunals, 82 ; foreign assessors in, 83

law administered by, 87

execution of sentences of, 89

jurisdiction over foreigners more than nine hours' travel from consular representative, 46

\section{$\mathrm{P}$}

\section{Partnership}

U. S. Consular Court Regulations, 126

Patriarchates

Investiture of Greek Patriarch by Mohammed the Conqueror, 18

claim jurisdiction in certain cases involving foreigners, 54

jurisdiction in questions involving personal status, 2I

Persia

practice concerning nationals sentenced by Turkish courts, 89

Personality of Law

as distinguished from territorial law, 12

respected by English in India, 24

Personal Status

meaning of term, 19

jurisdiction of Patriarchates in questions of, 2I

foreigners carry with them rights of, III

conflict of Moslem law with other law in respect to, II3

consular courts should have jurisdiction in matters involving personal status, 53, II

Phoenicians in Memphis, 9

Pisa

obtained privileges from Greeks and Saracens, I5

Police

powers of French Consul, 62

powers of American Consuls, 62

arrest of foreigners, 62 
Political Code, Moslem, 6

Porte, The Sublime, (see Imperial Divan)

formerly adjusted judicial questions involving foreigners, 36 negotiations for modification of exterritorial régime, 45

Portugal

treaty with Turkey, $4 \mathrm{I}$

claims criminal jurisdiction, 76

Post-offices (see Correspondence)

Practor Peregrinus, 19

Private International Law

relation to international law, I03-II2

international agreements respecting marriage, divorce, etc., 105

Third Hague Conference on, I05

opinions of continental publicists on, I06-1 Io

method of ascertaining foreign laws to be applied by courts, II5

Probate

U. S. Consular Court Regulations, I 26

Protégés, 93-95

policy of Powers in respect to, 93

consular protégés, 93

foreign protégés, 94

religious communities, 94

permanent and other protégés, 95

U. S. Consular Regulations, I 26

Protocol (see Real Estate)

Proxenoi, 9

Prussia (see Germany)

treaty with Turkey, $4 \mathrm{I}$

Punishment

in Turkish jails, 63

powers of U. S. Consular Courts, 64

practice of Powers in respect to nationals sentenced by

Turkish courts, 89

$\mathrm{R}$

Rayah, 19, 21

Real Estate

Law of I867 granting to foreigners right to own, 42 
Protocol defining status of foreigners owning Real Estate, 45 controversy as to jurisdiction in matters of rent, mortgage, inheritance, trademarks, 53

jurisdiction of Nizamich tribunals in matters relating to, 82 Reference

U. S. Consular Court Regulations, I23

Religious Communities

independent status of, 19

as protégés, 94

protection of individuals in, 94

Rent

customs exemptions of, 94

controversy as to jurisdiction in questions of, 53

jurisdiction of Ni amieh tribunals in matters of, 82

Replevin

U. S. Consular Court Regulations, 123

Rhodes, 8, г6

Roumania

practice in respect to nationals sentenced by Turkish courts, 89

Russia

early treaties with Byzantium, I I

treaty with Turkey, 4I

practice in respect to nationals sentenced by Turkish courts, 89

Safeguards, Guarantees

granted to non-Moslems, 4, 6

Sardinia

privileges of foreigners in, under Arabs, 24

treaty with Turkey, 4I

Scotland

allowed to adhere to Capitulations of 1535,34

Seamen

U. S. Consular Court Regulations, I 26

Servitude, International

customs dues in treaty with Venice constituted, 30 Sheri

base of all laws, 21,87

not applicable to Christians, 2I

invoked to supply deficiencies of civil and criminal codes, 88 
Sicily

local laws respected by Arabs in, 24

Soliman II

confirmed privileges granted Franks and Catalans in Alexandria, 32

entered into treaty with Francis I, 33

Soulh, 4, 29

Sovereignty

alienation of sovereign rights of Turkey, 68

respect for sovereign rights basis of future adjustments with Powers, II2

jurisdiction in matters affecting public law and order a Spain right of, 68

exterritorial privileges accorded by Visigoths in, to

local laws respected by Moors, 24

treaty with Turkey, 4I

practice regarding nationals sentenced by Turkish courts, 89 Summonses and sentences

of Turkish courts, 86

U. S. Consular Court Reuglations, I32

Suratt

forcible extradition from Egypt, 64

Sweden

treaty with Turkey, 4I

practice in respect to nationals sentenced by Turkish courts, 89

\section{$\mathrm{T}$}

Telonarii, so

Tender

U. S. Consular Court Regulations, I23

Territorial Law

a modern notion, I2

under theory of common law, I04

Testimony

of Christians not of equal value with Moslems', 36

Trademarks

jurisdiction claimed by consular courts, 54 
Treaties

Venetian Capitulations, 3I, 39

Capitulations of 1535,33

Capitulations of 1740,38

of European Powers with Turkey, 4I

Tribunaux Correctionnels.

jurisdiction over foreigners charged with crimes by Ottoman subjects, 82

Trustee Process

U. S. Consufar Court regulations, 122

Tunstall

forcible extradition of, from Morocco, 64

Turkey

rights of foreigners under international law in, I05

need of basis for adjustment of question of jurisdiction over foreigners between Powers and, II2

right of jurisdiction in all that affects public law and order, I 2

treaties with (see Treaties)

Turkish Tribunals (see Ottoman Tribunals)

U

United States

treaty with Turkey, $4 \mathrm{I}$

Article IV a precedent for other nations, 4I (see Article IV)

Real Estate Protocol signed by, 44

case of Vartanian and Afarian, 78

claims to jurisdiction in criminal cases, 76 (see Article IV) practice in respect to Americans sentenced by Turkish courts, 89

jurisdiction of French Consuls in, II5

Usury

not countenanced by Moslem law, 87

\section{V}

Vartanian

Venice

arrest and trial of, by Turks, 78

Venetian quarter in Constantinople, I3

privileges granted by Sultan of Aleppo, 16

treaty of 1454 with Turks, 29 
compensation for property of Venetians destroyed in capture of Constantinople, 29

customs dues fixed by treaty, 30

treaty with Sultan of Konia, 3I

privileges granted by Sultan of Egypt, 3I

Vessels

inviolability from search, 9I

jurisdiction of consuls over, i15

status determined by international law, I02

Visigoths

granted exterritorial privileges to foreigners in Spain, Io

\section{${ }_{s} \mathrm{~W}$}

Warings

early diplomatic relations with Byzantium, I I I

Wisby

privileges enjoyed by merchants of, I5

\section{$\mathrm{Y}$}

\section{Young Turks}

recognized national status of religious communities, 20

attempted compulsory military service of non-Moslem subjects, 20 




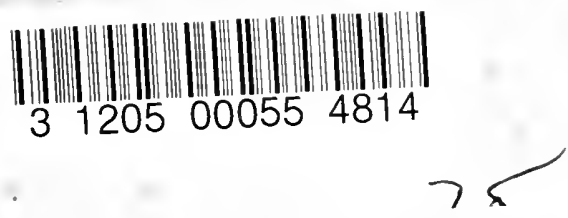

UC SOUTHERN REGIONAL LIBRARY FACILITY

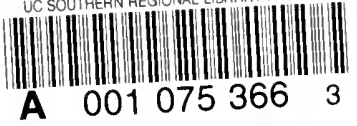


